\title{
TUNNUSLUVUT SÄVELMÄTUTKIMUKSEN APUNA
}

Kansansävelmä $\cdot$ muuntuminen $\cdot$ toisinto $\cdot$ toisintojoukko $\cdot$ valtatoisinto $\cdot$ tahtitoisinto $\cdot$ poikkeavuustahti $\cdot$ musiikillinen distribuutio $\cdot$ tunnusluku

\section{Johdanto}

Etnomusikologisissa tutkimuksissa on tilastollisia menetelmiä yleensä käytetty selvittämään tietyn musiikkikulttuurin tyylillisiä ominaisuuksia. Tällöin on tutkittu mm. sävelkorkeuksien jakautumia (Ling \& Jersild 1965) tai kansansävelmien luokittelua (Kluge 1974). Tilastollisia menetelmiä ei ole juurikaan sovellettu tietystä sävelmästä tavattavien toisintojen tutkimisessa. Kielitieteen puolella, erityisesti murretutkimuksissa, on tämäntapaisia tutkimuksia sen sijaan tehty (Nahkola 1985, 149-185).

Yhdysvaltalaisista strukturalisteista varsinkin Edward Sapir on kiinnittänyt huomiota kielen yksiköiden jakaumaan, kielelliseen distribuutioon (Sapir 1970 [1921]). Pohtiessaan kielellisen muutoksen syitä olettivat strukturalistit, että keskeinen syy on yksittäisten puhujien äänentuotoksen horjunnassa (parole). Ranskalainen Martinet on muotoillut periaatteet seuraavasti: foneemeilla on hajontakenttä, joka muodostuu foneemin mahdollisista tuotoksista eli allofoneista. Foneemien erillään pysymistä varmistaa erityinen varokaista, joka erottaa vierekkäisten foneemien hajontakentät toisistaan. Jos foneemien tuotokset alkavat painottua naapurifoneemin suuntaan, saattavat foneemit sekoittua keskenään. Jotta foneemit pysyisivät erillään, on myös toisen foneemin hajontakentän siirryttävä. Tästä voi olla seurauksena ketjureaktio. (Martinet 1952).

Samantapaisia ilmiöitä on havaittavissa myös musiikillisessa distribuutiossa. Tietyt sävelmäkohdat sisältävät runsaasti hajontaa eli tietystä tahdista tai säkeestä tavataan useita erilaisia, toisiaan muistuttavia toisintoja (allofoneja). Jotkut paradigmoista (foneemeista) ovat saavuttaneet kiinteän muodon, eivätkä ne sekoitu keskenään, kun taas jotkut ovat hyvin alttiita vaihtelulle. Tietyt sävelmät näyttävät saavuttaneen vakiintuneen aseman eli ne esiintyvät lähes aina samassa muodossa perinnealueen eri osissa, kun taas tietyt sävelmät muuttavat asuaan lähes joka esityskerralla ja lisäksi eri kylissä sävelmästä käytetään eri toisintoa. 
Myös sävelmien sisällä tavataan vaihtelua siten, että tietyt sävelmäkohdat veisataan poikkeuksetta samalla tavalla, kun taas tietyt kohdat vaihtelevat samallakin veisaajalla esityskerrasta toiseen. Kyetäksemme selvittämään näitten ilmiöitten mahdollisia syitä, on meidän ensiksi kehitettävä menetelmä, jonka avulla voimme suuresta tutkimusmateriaalista löytää sävelmät, jotka täyttävät tietyt ehdot.

Luonnollisesti myös tarkastelemalla silmämääräisesti allekkain merkittyjä sävelmän toisintoja voimme etsimiämme toisintotyyppejä löytää, mutta jos haluamme etsiä sävelmiä, jotka täyttävät samanaikaisesti useita ehtoja ei silmämääräinen tarkastelu enää riitä.

\section{Toisintojoukkoja kuvaavat tunnusluvut}

Tässä artikkelissa ei tulla keskittymään melodisiin tai muihin toisintojen vălisiin laadullisiin eroihin vaan ennen kaikkea toisintojoukon tilastollisiin ominaisuuksiin, musiikilliseen distribuutioon. Tavoitteena on kehittää tunnuslukuja, joiden avulla voidaan suuresta tutkimusmateriaalista löytää toisintojoukot, joissa esiintyy tietynlaista musiikillista hajontaa. Tunnuslukujen avulla saadaan näin ollen tutkittavaksi toisintojoukot, joiden avulla päästään syvällisemmin tutkimaan musiikillisen distribuution luonnetta.

Tutkimuksessa on valittu kahdeksan tunnuslukua, joiden oletetaan olevan toisintojoukon tutkimisen kannalta keskeisiä. Tunnuslukujen toimivuutta on tutkittu valitsemalla kymmenen toisintojoukkoa, jotka on valittu siten, että ne mahdollisimman hyvin osoittaisivat tunnusluvuissa mahdollisesti olevia puutteita. Tunnuslukujen avulla on myöhemmin tarkoitus selvittää, mitkä ovat keskeisiä toisintojoukon yhtenäisyyteen ja musiikilliseen muutokseen vaikuttavia tekijöitä.

Tilastollinen tarkastelu antaa myös sävelmien historialliselle tarkastelulle uutta sisältöä. Voidaan kysyä, onko lainkaan mielekästä tutkia yksittäisen sävelmän kehitystä, koska sävelmä ei kenties missään vaiheessa ole ollut tietyssä muodossa. Sävelmän tallentanut tutkija on saanut tallennetuksi kenties vain yhden sävelmän useista yhtäaikaa esiintyvistä muodoista.

Mielekkäämpää on tarkastella toisintojoukon ominaisuuksien muuttumista. Sävelmän kaikki eri toisinnot saattavat olla käytössä, mutta niiden keskinäiset suhteet saattavat muuttua. Esimerkiksi sävelmästä $a$ saattaa olla muotoja, joissa vain ensimmäisessä tahdissa on eroavuutta. Tämä ominaisuus saattaa säilyä vuosikausia, mutta vähitellen harvinaisemmat tahtitoisinnot jäävät pois käytöstä (ks. Louhivuori 1986, 151). Olennaista on siis huomata, että sävelmässä ja sen toisinnoissa on kyse tietyillä todennäköisyyksillä manifestoituvista paradigmakombinaatioista.

Tutkimusmateriaalissa on otettu huomioon vain se, onko toisintojen välistä eroa pidettävä huomattavana, runkosäveliin ulottuvana, vai vähäisenä, hajasäveliä koskevana. Huomio kiinnitetään vain melodisiin eroihin. Rytmisiä tai sävelmän muotoon liittyviä eroavuuksia ei ole tässä vaiheessa otettu tarkasteluun mukaan 
mm. siksi, että tutkittavassa materiaalissa on rytmi sidottu sävelmissä käytettyihin teksteihin.

On totta, että jako huomattaviin ja vähäisiin eroihin ei ole yksiselitteinen tehtävä. Mikäli vertaillaan runkosäveliä, on päätettävä mikä sävel on runkosävel ja mikä ei. Jakoperusteena on pidetty sitä, että jos pää- ja sivuiskuilla olevat sävelet eroavat sävelkorkeuden suhteen, on kyse runkosävelerosta, mutta niiden väliin sattuvia eroja pidetään hajasäveleroina.

Käytännössä ei ole aina selvää, mikä on pää- tai sivuisku. Tässä onkin yksi ilmeinen toisintojen synnyn syy: laulajat tai soittajat eivät hahmota sävelmän iskutusta samalla tavalla. Tällöin mahdollisuus uuden toisinnon syntyyn on varsin suuri.

\section{Tutkimusmenetelmästä}

Käytetty tutkimusmenetelmä on läheistä sukua ns. paradigmaattiselle musiikkianalyysille. Tätä menetelmää ovat käyttäneet mm. Knudsen \& Nielsen \& Schiörring (1976), Jean-Jacques Nattiez $(1982,95)$ ja suomalaisista musiikintutkijoista mm. Erkki Pekkilä (1981). Käyttämäni lähestymistapa poikkeaa aikaisemmista tutkimuksista siinä, että tutkin sävelmien paradigmarakennetta tilastollisesta näkökulmasta (vrt. Louhivuori 1983).

Käyttämääni tilastollista lähestymistapaa muistuttavia tutkimuksia löytyy enemmän kielitieteen puolelta. Esimerkkinä mainittakoon William Labovin sosiolingvistisistä tutkimuksista kehittynyt ns. kvantitatiivinen malli, joka tutkii puhujaryhmien (vrt. toisintojoukon käsite) variaatiota. Kvantitatiivisen mallin vaihtelusäännöt (variable rules) antavat tietoja varianttien esiintymistaajuuksista puhujaryhmissä. (Labov 1969).

\section{Sävelmän ja toisintojoukon yhtenäisyyttä kuvaavat tunnus- luvut}

\section{TUNNUSLUKU I}

Tunnusluvussa I tarkastellaan sävelmässä olevien poikkeavuustahtien lukumäärän suhdetta sävelmän tahtien kokonaismäärään. Tunnuslukua voidaan nimittää sävelmän yhtenäisyyskertoimeksi ja sitä merkitään $\mathrm{Y}^{\mathrm{S}}$. Tunnusluku lasketaan kaavasta

$$
\begin{aligned}
& \mathrm{Y}^{s}=\mathrm{Pt} / \mathrm{sp} \\
& \text { jossa } \mathrm{Pt}=\text { sävelmässä olevien poikkeavuustahtien lukumäärä } \\
& \mathrm{sp}=\text { sävelmässä olevien tahtien lukumäärä }
\end{aligned}
$$


Kuvassa 1 on tilanne, jossa kaikki sävelmän tahdit ovat poikkeavuustahteja (ks. sävelmä n:o 187). Kuvassa 2 on tilanne, jossa poikkeavuustahteja on suhteellisen vähän verrattuna sävelmän pituuteen (ks. sävelmä n:o 155).

Kuva 1. Sävelmä, jonka kaikki tahdit ovat poikkeavuustahteja.

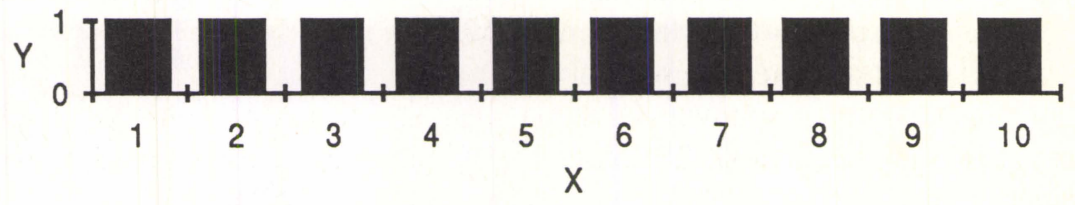

Kuvan 1 tapauksessa on sävelmän $\mathrm{Y}^{\mathrm{s}}$-arvo $10 / 10=1$.

Kuva 2. Sävelmä, jossa vain osa tahdeista on poikkeavuustahteja.

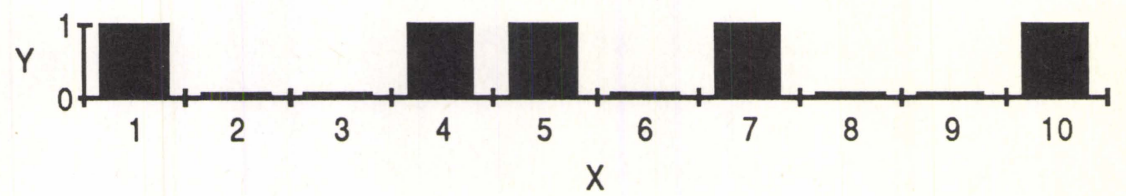

Kuvan 2 tapauksessa on sävelmän $\mathrm{Y}^{\mathrm{s}}$-arvo $5 / 10=0,5$

$Y^{S}$-arvo antaa kuvan sävelmän yhtenäisyydestä. Mitä lähempänä $Y^{S}$ on arvoa 1 sitä epäyhtenäisempi sävelmä on ja mitä lähempänä se on arvoa 0 sitä yhtenäisempi sävelmä on.

Tunnusluvun käyttöarvoa vähentää se, että siinä ei oteta lainkaan huomioon toisintojen määrää. Suuressa toisintojoukossa on luonnollisesti todennäköisempää kuin pienessä, että jossakin toisinnoista on poikkeavuutta muihin toisintoihin verrattuna. Tunnusluku ei myöskään ota huomioon poikkeavuuksien yleisyyttä. Toisintojoukossa saattaa olla parikymmentä toisintoa ja näistä vain yhdessä toisinnossa on jokaisessa tahdissa eroavuuksia muihin toisintoihin verrattuna. Tämä yksinäinen toisinto kuitenkin aiheuttaa sen, että tunnusluku saa arvon yksi (ks. esimerkiksi sävelmä n:o 2). Saman arvon saisi toisintojoukko, jossa kaikki toisinnot ovat keskenään erilaisia.

\section{TUNNUSLUKU II}

Tunnusluvussa II lasketaan poikkeavuustahtien frekvenssien summan suhde toisintojoukon tahtien kokonaismäärään. Tunnuslukua voidaan nimittää toisintojoukon yhtenäisyyskertoimeksi ja sitä merkitään $\mathrm{Y}^{\mathrm{t}}$. Tunnusluku lasketaan kaavasta

$$
\begin{aligned}
& \mathrm{Y}^{\mathrm{t}}=\mathrm{Ptf} / \mathrm{sp} \times \mathrm{tf} \\
& \text { jossa } \mathrm{Ptf}=\text { sävelmässä olevien tahtitoisintojen lukumäärä } \\
& \mathrm{sp}=\text { sävelmän pituus ja } \\
& \mathrm{tf}=\text { toisintojen lukumäärä }
\end{aligned}
$$


Tunnusluvun etuna edelliseen verrattuna on se, että tämä ottaa huomioon tahtitoisintojen määrän. Näin ollen toisintojoukot, joissa kaikki sävelmän tahdit ovat poikkeavuustahteja, mutta jossa toisessa on kussakin poikkeavuustahdissa runsaasti tahtitoisintoja kun taas toisen poikkeavuustahdeissa on esimerkiksi vain yksi tahtitoisinto, saavat eri arvon (ks. kuva 3 ja 4).

Kuva 3. Toisintojoukko, jonka kaikki tahdit ovat poikkeavuustahteja ja kussakin poikkeavuustahdissa on vain yksi tahtitoisinto.

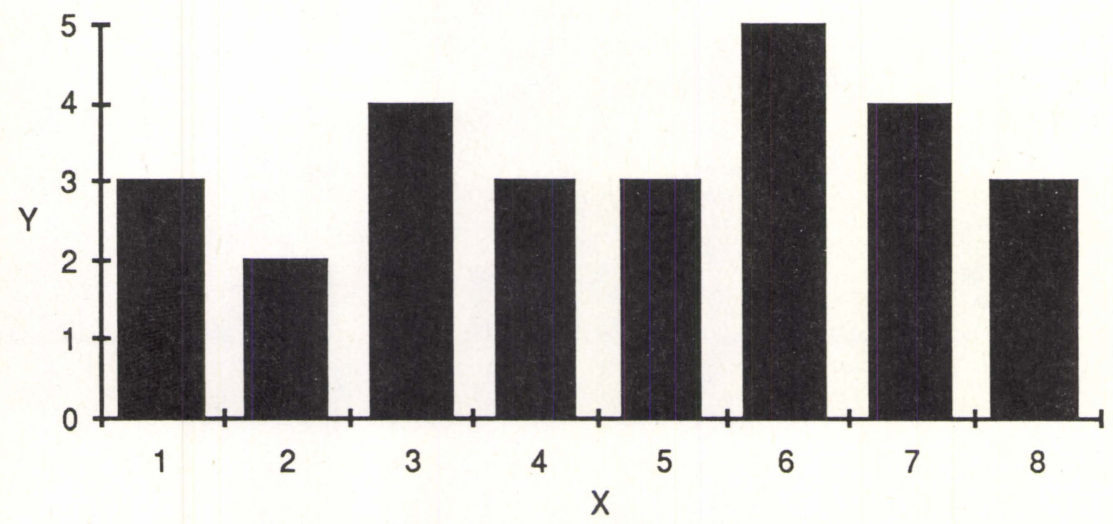

Kuva 4. Toisintojoukko, jossa on sama poikkeavuustahtien määrä kuin kuvassa 3, mutta jossa tahtitoisintojen määrä on suurempi.

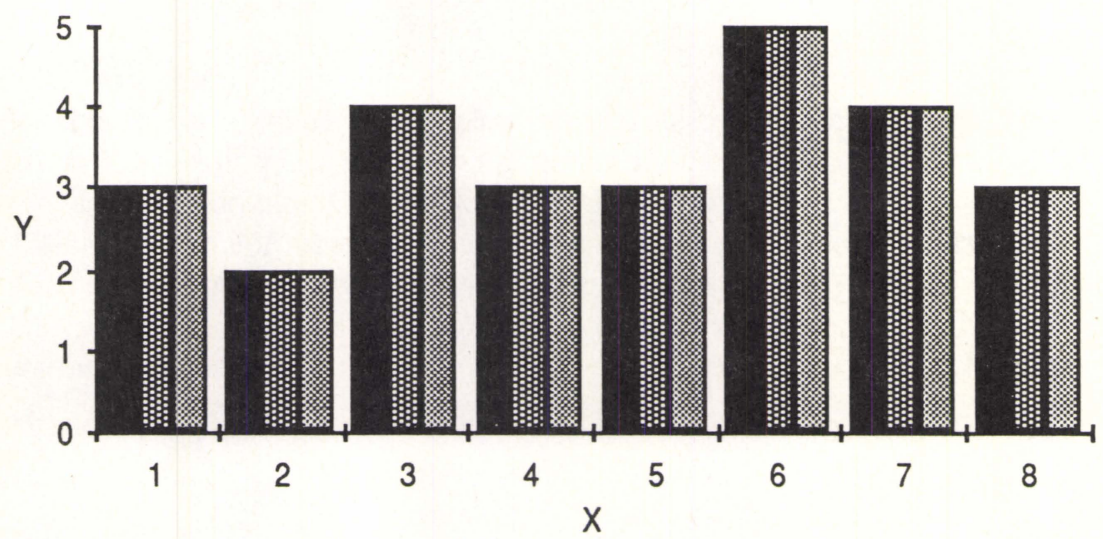

Tunnusluvun puutteena on se, ettei se ota huomioon sitä kuinka suuressa osassa sävelmää poikkeavuutta esiintyy. Kuvassa 5 on tilanne, jossa tahtitoisintojen määrä on sama, mutta toisessa toisintojoukossa ovat poikkeavuudet jakautuneet tasaisesti pitkin sävelmä kun taas toisessa ne ovat keskittyneet tiettyyn tahtiin. 
Kuva 5. Toisintojoukot, joissa on sama määrä tahtitoisintoja, mutta ne ovat jakautuneet sävelmään eri tavoin.

tf

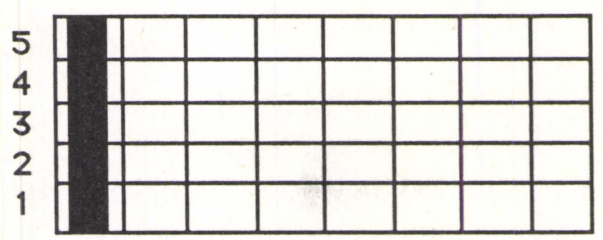

$\begin{array}{lllllllll}1 & 2 & 3 & 4 & 5 & 6 & 7 & 8 & \text { sp }\end{array}$
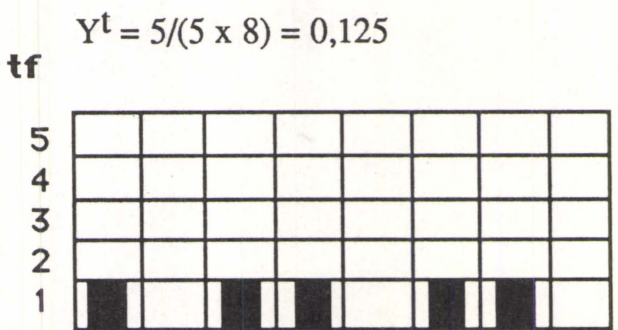

$\begin{array}{lllllllll}1 & 2 & 3 & 4 & 5 & 6 & 7 & 8 & \text { sp }\end{array}$

$$
\mathrm{Y}^{\mathrm{t}}=5 /(5 \times 8)=0,125
$$

Tunnusluvun puute voidaan kompensoida tarkkailemalla samanaikaisesti sävelmän ja toisintojoukon yhtenäisyyskertoimia.

\section{TUNNUSLUKU III}

Tunnusluvussa III tarkastellaan tahtitoisintojen keskimääräisen lukumäärän suhdetta sävelmästä tavattavien toisintojen kokonaisfrekvenssiin (= tf). Tunnuslukua nimitetään poikkeavuustahtien suhteelliseksi frekvenssiksi ja sitä merkitään $\mathrm{Pp} / \mathrm{t}$. Se saadaan laskemalla poikkeavuustahtien tahtitoisintojen lukumäärän keskiarvon suhde toisintojen kokonaismäärään kaavalla

$$
\begin{aligned}
& \mathrm{Pp} / \mathrm{t}=\mathrm{ttf}^{\mathrm{av}} / \mathrm{tf} \\
& \text { jossa } \mathrm{ttf}^{\mathrm{av}}=\text { poikkeavuustahtien tahtitoisintojen lukumäärän keskiarvo ja } \\
& \quad \mathrm{tf}=\text { toisintojen kokonaismäärä }
\end{aligned}
$$

Toisintojoukon yhtenäisyyskertoimen puutteena on, ettei se ota huomioon tahtitoisintojen frekvenssejä. Poikkeavuustahtien suhteellisen frekvenssin avulla saadaan selville se, kuinka suuressa osassa toisintoja käytetään muista poikkeavaa muotoa. Voidaan olettaa tilanne, jossa kaikissa toisinnoissa ja kaikissa toisintojen tahdeissa käytetään toisistaan poikkeavia muotoja eli kaikkien toisintojen kaikki tahdit poikkeavat toisistaan (ks. kuva 6; vrt. sävelmä n:o 29 
b). Tällöin $\mathrm{Pp} / \mathrm{t}$ saa saman arvon kuin $\mathrm{Y}^{\mathrm{t}}$. Kuvan 7 tilanteessa ei mitään toisinnoista tavata kaikilta veisaajilta (ks. sävelmä n:o 34).

Kuva 6. Toisintojoukko, jossa kaikissa poikkeavuustahdeissa ja kaikissa sävelmän toisinnoissa (tf $=5$ ) käytetään erilaista muotoa.

\section{Toisinto jen māārā (tf)}

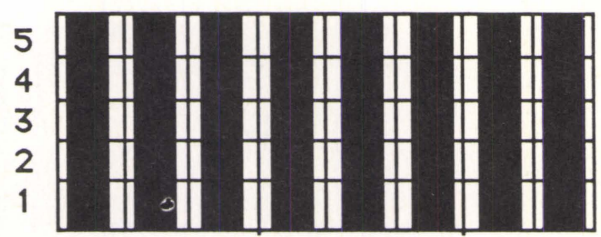

$\begin{array}{llllllll}1 & 2 & 3 & 4 & 5 & 6 & 7 & 8\end{array}$

Tahtien māārā

= sārelmān pituus (sp)

Kuvan 6 tilanteessa saa $\mathrm{Pp}^{\mathrm{t}}$-arvon $5 / 5=1$.

Kuvien 1 ja 6 tapauksissa huomataan sävelmän yhtenäisyyskertoimen puute: kuvissa 1 ja 6 on sävelmien $\mathrm{YS}^{\mathrm{S}}$-arvo sama $(10 / 10=1 ; 8 / 8=1)$, vaikka kuvan 6 tilanteessa on poikkeavuustahdeissa huomattavasti enemmän tahtitoisintoja kuin kuvan 1 tapauksessa.

\section{TUNNUSLUKU IV}

Tunnusluvussa IV tarkastellaan poikkeavuustahtien tahtitoisintojen lukumäärän hajontaa. Tunnuslukua voidaan nimittää poikkeavuustahtien yhtenäisyydeksi ja sitä merkitään YP. Kuva 7 vastaa tilannetta, jossa poikkeavuustahtien tahtitoisintojen lukumäärä vaihtelee (ks. sävelmä n:o 155 ja187) ja kuva 8 tilannetta, jossa lukumäärä ei vaihtele (ks. sävelmä n:o 17). 
Kuva 7. Toisintojoukko, jossa poikkeavuustahdeissa olevien tahtitoisintojen lukumäärä vaihtelee. Tahdissa 1 on tahtitoisintojen lukumäärä neljä eli $\mathrm{pt}^{1} \mathrm{f}=4$, $\left.\mathrm{pt}^{2} \mathrm{f}=1, \mathrm{pt}^{5} \mathrm{f}\right)=2, \mathrm{pt}^{6} \mathrm{f}=5 \mathrm{ja} \mathrm{pt}^{10} \mathrm{f}=3$. Kaikissa tahdeissa on toisintofrekvenssi sama $(\mathrm{ttf}=3)$

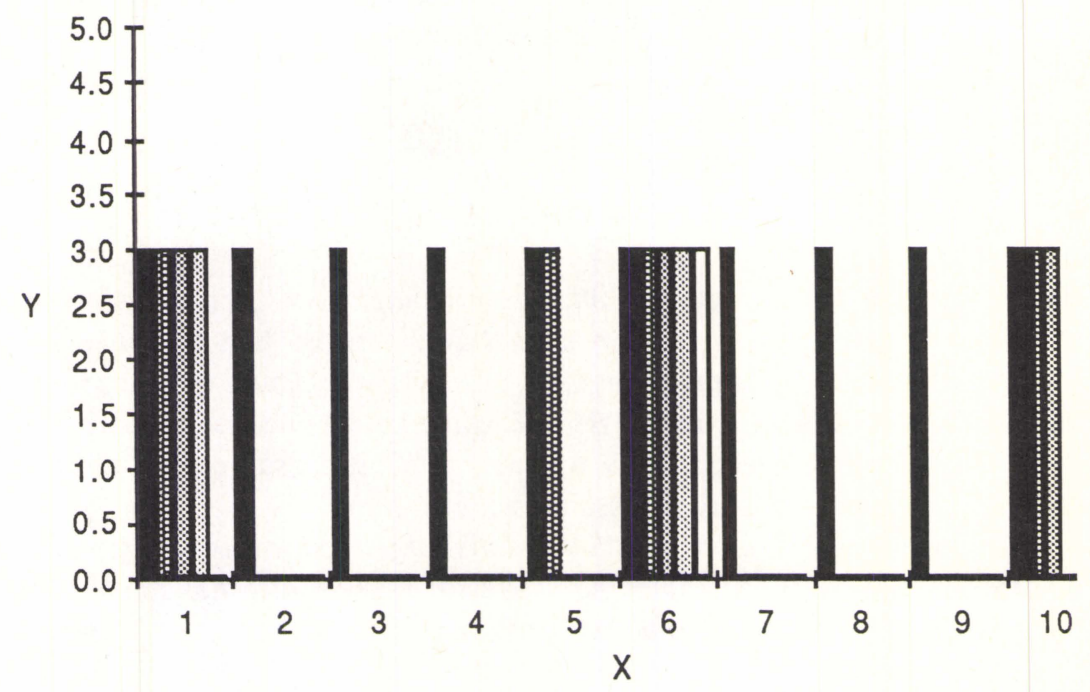

Kuva 8 vastaa tilannetta, jossa tahtitoisintojen lukumäärän hajonta saa arvon 0 .

$K u v a$ 8. Toisintojoukko, jossa poikkeavuustahtien frekvensseissä ei ole hajontaa.

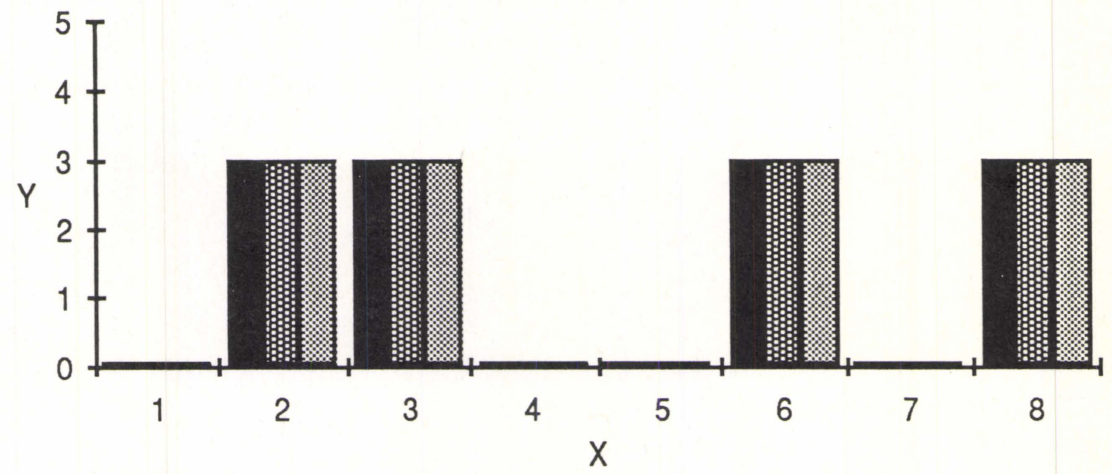

Poikkeavuustahtien suhteellinen frekvenssi antaa yleiskuvan tahtitoisintojen lukumäärästä, mutta siitä ei voida päätellä onko niitten lukumäärässä hajontaa eli keskittyvätkö tahtitoisinnot tiettyyn tahtiin. Tämän vuoksi on tarpeen tarkastella myös poikkeavuustahtien yhtenäisyyskertoimen arvoa. Mikäli hajonta on pieni on toisintojoukko tahtitoisintojen lukumäärän suhteen yhtenäinen. Tämä ei 
merkitse tietenkään sitä, että sävelmässä ei olisi tahtitoisintoja vaan ainoastaan, että niitten määrä ei vaihtele.

Toisintojoukko saattaa olla siinä mielessä yhtenäinen, että siinä on tietty määrä toisistaan selvästi poikkeavia toisintoja, mutta kutakin toisintomuotoa tavataan usealta veisaajalta (ks. sävelmä n:o 97, tahdit 7-11). Toisaalta toisintojoukko saattaa olla yhtenäinen siten, että kaikki käyttävät samaa toisintoa, mutta tietyistä tahdeista tavataan useita tahtitoisintoja (ks. sävelmä n:o 155 , tahti 5).

\section{TUNNUSLUKU V}

Tunnusluvussa V tarkastellaan poikkeavuustahtien maksimitoisintofrekvenssien keskiarvoa. Sävelmätutkimuksen kannalta on tarpeen tietää, kuinka suuri osa veisaajista käyttää yleisimmin käytössä olevaa tahtitoisintoa. Poikkeavuustahtien maksimitoisintofrekvenssien keskiarvo antaa kuvan siitä, onko kussakin sävelmän poikkeavuustahdeissa tietty toisinto, jota suuri osa veisaajista käyttää eli onko toisintojoukosta löydettävissä ns. valtatoisinto.

Tunnuslukua voidaan nimittää valtatoisintojen suhteelliseksi keskiarvoksi ja sitä merkitään Vav/t. Tunnusluku saadaan laskemalla maksimitoisintofrekvenssien keskiarvon suhde toisintojen kokonaismäärään.

$$
\begin{aligned}
& \mathrm{V}^{\mathrm{av}} / \mathrm{t}=\operatorname{tt}(\max )^{\mathrm{av}} / \mathrm{tf} \\
& \text { jossa, } \operatorname{ttf}(\max )^{\mathrm{av}}=\text { maksimitoisintofrekvenssien keskiarvo ja } \\
& \text { tf }=\text { toisintojen kokonaismäärä }
\end{aligned}
$$

Tunnusluku saa arvon 1 mikäli kaikissa poikkeavuustahdeissa maksimitoisintofrekvenssi on sama kuin toisintojen kokonaismäärä (ks. sävelmä n:o 2). Tunnusluku lähenee arvoa 0 sitä enemmän mitä pienempi on maksimitoisintofrekvenssi suhteessa toisintojen kokonaismäärään (ks. sävelmä n:o 34).

Kuva 9 vastaa tilannetta, jossa yleisin tahtityyppi tavataan kaikista toisinnoista. Kuva 10 vastaa tilannetta, jossa yleisin tahtityyppi tavataan vain muutamasta toisinnosta. 


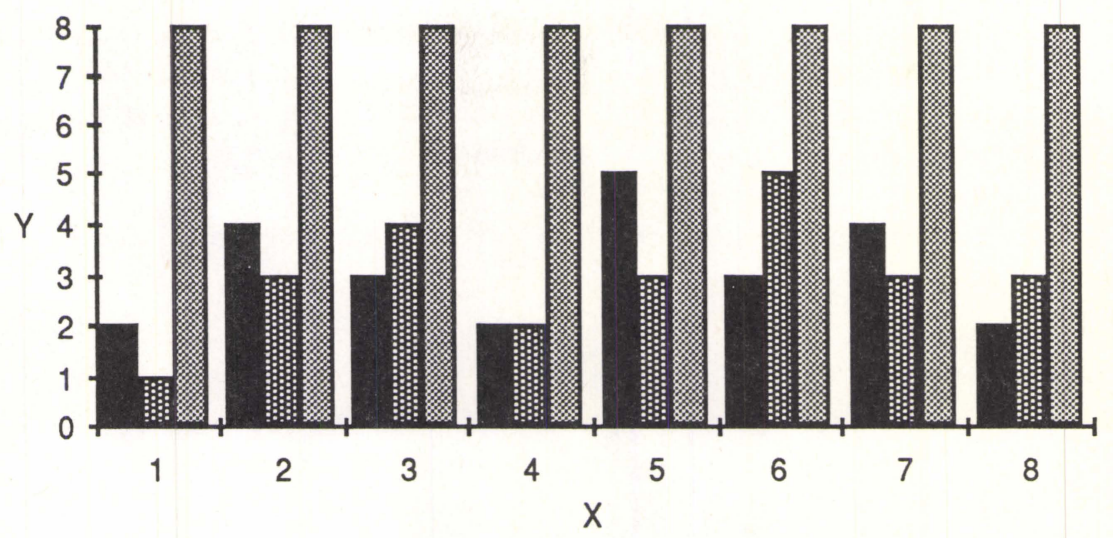

Kuva 10. Toisintojoukko, jossa valtatoisinto tavataan vain muutamasta toisinnosta.

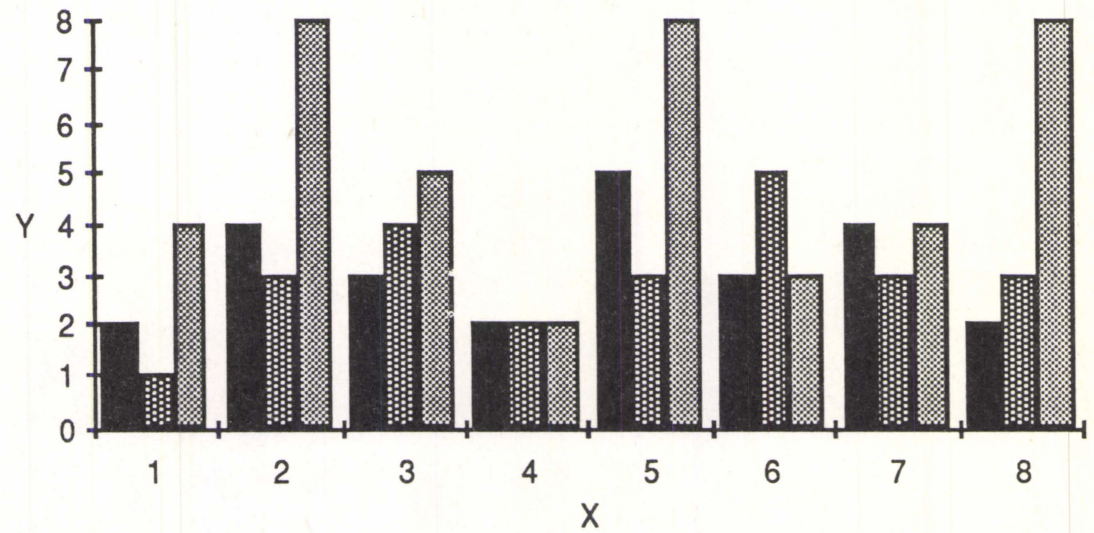

Tunnuslukua käytettäessä on huomattava mahdollisuus, että myös muiden kuin valtatoisintojen frekvenssit ovat korkeat; ts. on varottava tekemästä päätelmää, että korkea $\mathrm{V}^{\mathrm{av} / \mathrm{t}}$ arvo merkitsisi sitä, että tahtitoisintojen frekvenssien erot olisivat suuret. Tämä tutkimiseksi voidaan käyttää seuraavaa tunnuslukua.

\section{TUNNUSLUKU VI}

Tunnusluvussa VI tarkastellaan maksimitoisintofrekvenssien hajontaa. Tunnuslukua voidaan nimittää valtatoisintojen yhtenäisyyskertoimeksi ja sitä merkitään $\mathrm{Y}^{\mathrm{v}}$.

Kuvan 11 tilanteessa toisintojoukon poikkeavuustahtien tahtitoisintojen maksimifrekvenssit vaihtelevat. Mikäli samalla valtatoisintojen suhteellinen 
keskiarvo on matala tarkoittaa tämä sitä, että sävelmästä ei ole toisintoa, joka selvästi erottuisi muita yleisemmäksi eli muotoa, jota lähes kaikki veisaajat käyttäisivät (ks. sävelmä n:o 158). Sen sijaan sävelmässä on muutama tahtitoisinto, joka tavataan kaikista toisinnoista (ks. tahdit 9, 27 ja 31). Kuvan 12 tilanteessa tahtitoisintojen lukumäärä ei juurikaan vaihtele. Mikäli valtatoisintojen suhteellinen keskiarvo on samalla korkea on olemassa toisinto, jota suuri osa veisaajista käyttää (ks. sävelmä n:o 2).

Kuva 11. Toisintojoukko, jossa poikkeavuustahtien tahtitoisintojen maksimifrekvenssit vaihtelevat.

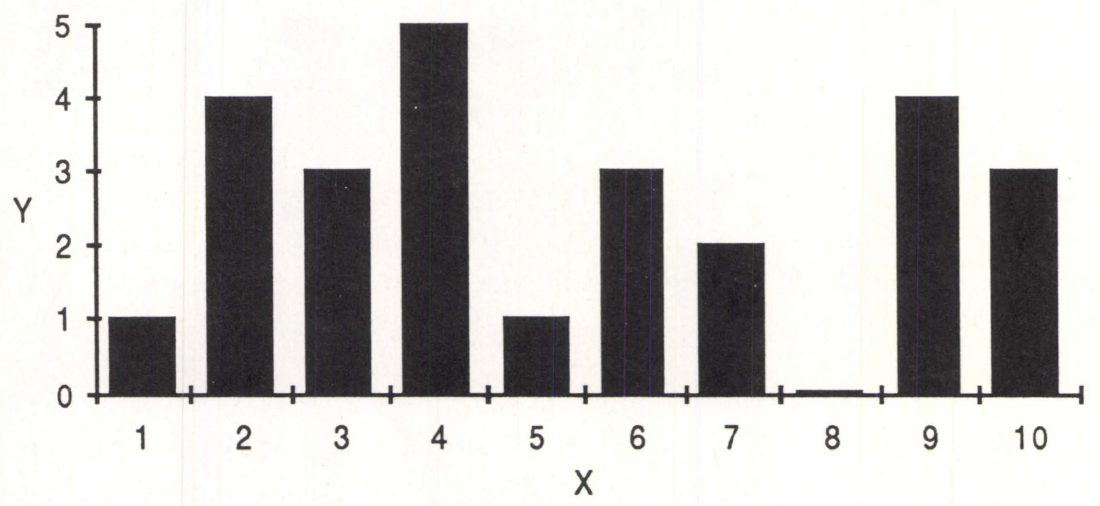

Kuva 12. Toisintojoukko, jossa poikkeavuustahtien tahtitoisintojen maksimifrekvenssit eivät vaihtele.

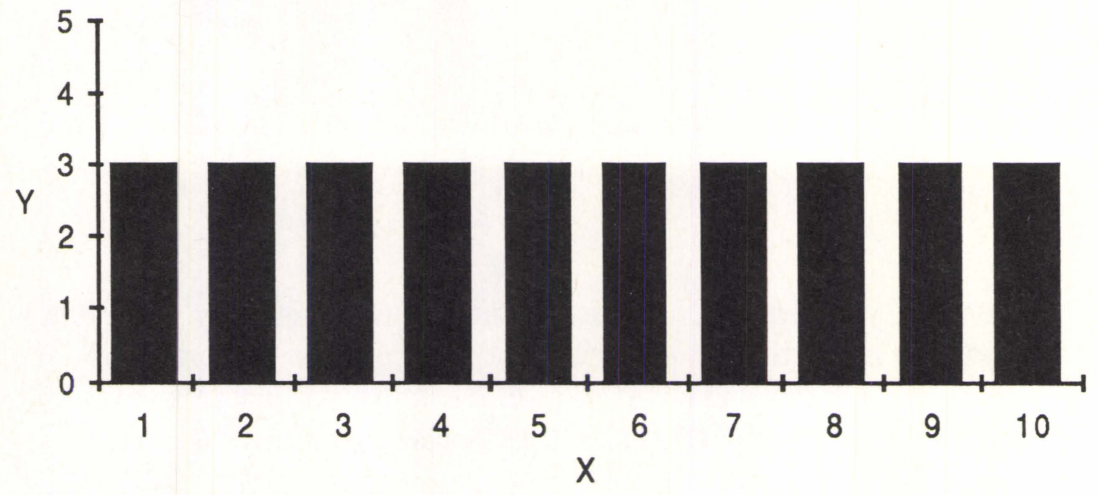

Kuvan 12 tapauksessa $Y^{\mathbf{v}}=0$.

Myös valtatoisintojen yhtenäisyyskerroin antaa yleiskuvan toisintojoukon yhtenäisyydestä, mutta toisin kuin valtatoisintojen suhteellinen keskiarvo niin tämä ei anna kuvaa siitä onko toisintojoukossa muista erottuvaa valtatoisintoa, vaan ainoastaan sen, käyttäytyvätkö valtatoisinnot samalla tavoin eri poikkeavuustahdeissa. Tietyille sävelmille näyttää olevan ominaista se, että suuri osa 
veisaajista käyttää tiettyä valtatoisintoa (ks. sävelmä n:o 2). Muutamissa toisintojoukoissa ei kuitenkaan mikään tahtityyppi ole saavuttanut valtatoisinnon asemaa. Poikkeavuustahdissa on joko muutama yhtä yleinen tahtitoisinto tai useita, mutta vähän käytettyjä tahtitoisintoja (ks. sävelmä n:o 34). Yleistä näyttää olevan se, että suuri osa toisinnoista keskittyy tiettyyn tahtitoisintoon, mutta muutamassa poikkeavuustahdissa ei mikään tahtitoisinto ole saavuttanut valta-asemaa (ks. sävelmä n:o 113, tahti 8 ).

\section{TUNNUSLUKU VII}

Tunnusluvussa VII tarkastellaan poikkeavuustahtien tahtitoisintojen frekvenssien hajontaa (kuva 13). Tunnuslukua voidaan nimittää tahtitoisintojen yhtenäisyyskertoimeksi ja sitä merkitään $\mathrm{Y}^{\mathrm{tt}}$. Tunnusluku saadaan laskemalla kustakin poikkeavuustahdista tahtitoisintojen frekvenssien hajonta ja laskemalla näitten hajonta koko sävelmässä. Tunnusluvun avulla saadaan kuva siitä, keskittyvätkö poikkeavuustahdeissa olevat tahtitoisinnot tiettyyn toisintoon, vai onko toisintojoukossa useita yhtä yleisesti käytössä olevia tahtitoisintoja.

Kuvassa 7 on tapaus, jossa poikkeavuustahtien tahtitoisinnoissa on aina sama frekvenssi eli $\mathrm{Y}^{\mathrm{tt}}=0$. Käytännössä tällainen tilanne on harvinainen. Yleisempää näyttää olevan, että yksittäisissä tahdeissa tavataan useita yhtä yleisesti käytössä olevia tahtitoisintoja (ks. sävelmä n:o 113, tahti 8). Kuvassa 13 on tapaus, jossa poikkeavuustahtien ttf-arvot vaihtelevat (ks. sävelmä n:o 158).

Kuva 13. Toisintojoukko, jossa poikkeavuustahtien tahtitoisintojen frekvenssit vaihtelevat.

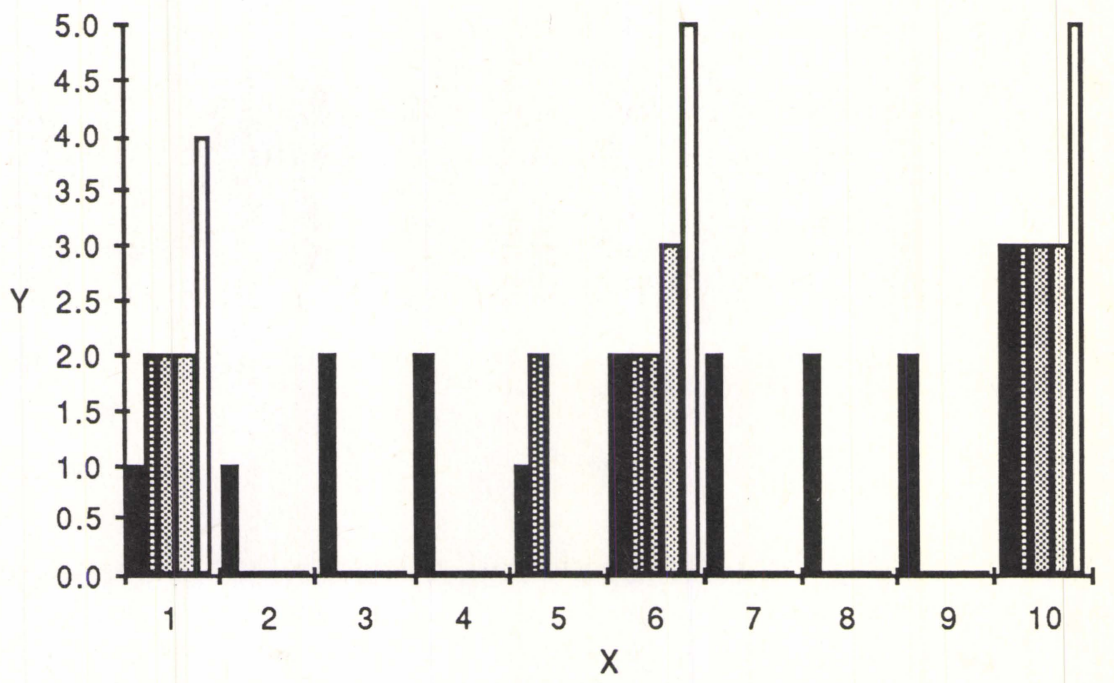


Kuvan 13 tapauksessa on yleisin poikkeavuustahtien tahtitoisintojen frekvenssi 2 . Tahdeissa 1,6 ja 10 on tahtitoisintojen frekvensseissä huomattavaa hajontaa. Esimerkiksi poikkeavuustahdin 1 tahtitoisintoa 1 käyttää vain yksi veisaajaa, tahtitoisintoja 2-4 käyttää kaksi veisaajaa ja tahtitoisintoa 5 käyttää neljä veisaajaa.

\section{TUNNUSLUKU VIII}

Tunnusluvussa VIII tarkastellaan poikkeavuustahtien sijaintia. Tätä kuvataan tunnusluvulla $\mathrm{P}^{\mathrm{si}}$. Sijaintiluvulla pyritään kuvaamaan poikkeavuustahtien sijoittumista sävelmän eri osiin. Tunnusluku voidaan laskea kaavasta

$$
\begin{aligned}
& \mathrm{Ps}^{\mathrm{si}}(\mathrm{A})=\sum(\mathrm{a} \times \mathrm{tn} / \mathrm{sp}) \\
& \text { jossa a:n arvo riippuu siitä, onko tahdissa eroavuutta vai ei } \\
& \mathrm{a}=0, \text { jos tahdissa ei ole eroavuutta ja } \\
& \mathrm{a}=1, \text { jos tahdissa on eroavuutta } \\
& \mathrm{tn}=\text { tahdin järjestysnumero } \\
& \mathrm{sp}=\text { sävelmän pituus }
\end{aligned}
$$

Mitä lähempänä sävelmän alkua eroavuutta on, sitä pienemmän $\mathrm{P}^{S i_{-} \text {-arvon }}$ toisintojoukko saa ja kääntäen, mitä kauemmaksi eroavuus keskittyy sitä suuremman PSi-arvon toisintojoukko saa.

Tässä yhteydessä tarkastellaan poikkeavuustahtien sijaintia vain "silmämääräisesti" pääluokittain käyttämättä yllä mainittua kaavaa. Poikkeavuustahtien sijainti voidaan luokitella seuraaviin ryhmiin.

a. Poikkeavuustahtien sijainti on systemaattista
a.a. Poikkeavuustahdit sijaitsevat tietyissä sävelmän kohdissa
a.b. Poikkeavuustahdit sijaitsevat tietyissä säkeissä
a.c. Poikkeavuustahdit sijaitsevat tietyissä tahdeissa

b. Poikkeavuustahtien sijainti on epäsystemaattista 
Kuva 14. Hypoteettinen toisintojoukko, jossa poikkeavuustahdit ovat sijoittuneet sävelmän alkupuoliskolle.

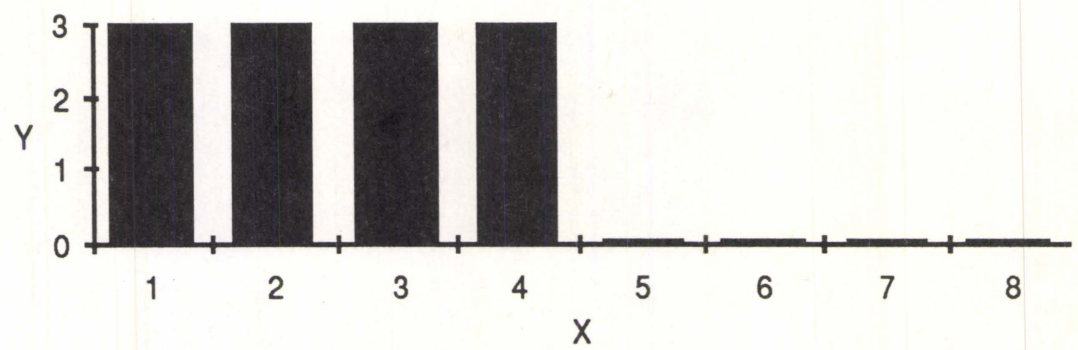

Kuva 15. Hypoteettinen toisintojoukko jossa poikkeavuustahdit ovat sijoittuneet sävelmän loppupuolelle.

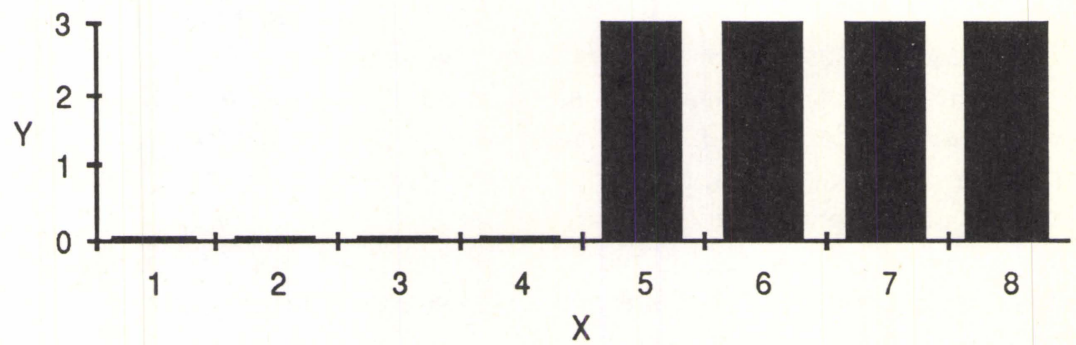

Kuva 16. Hypoteettinen toisintojoukko, jossa poikkeavuustahdit ovat sijoittuneet säkeitten alkuun.

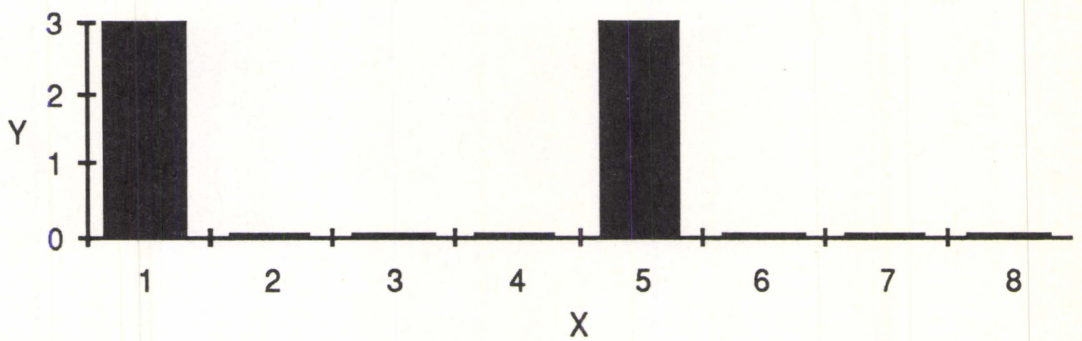


Kuva 17. Hypoteettinen toisintojoukko, jossa poikkeavuudet sijaitsevat satunnaisesti.

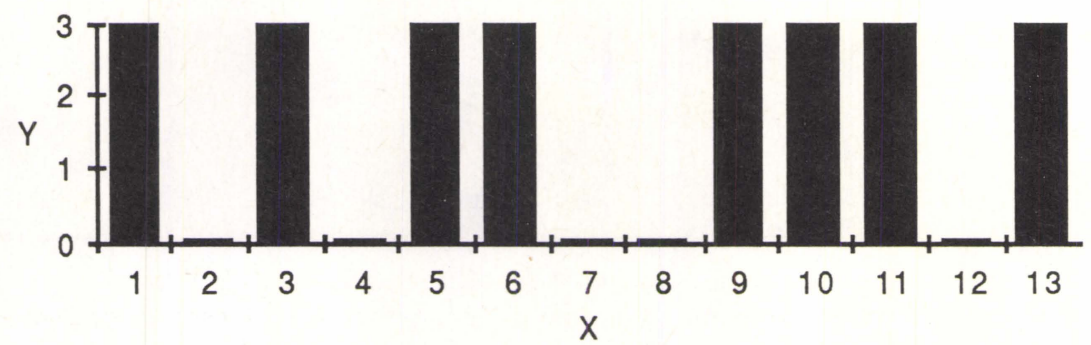

\section{Esimerkkitapaukset}

Tutkimusmateriaalista on valittu kymmenen sävelmää, joiden avulla pyritään testaamaan tunnuslukujen soveltuvuutta sävelmätutkimuksen apuna. Valinnassa on pyritty siihen, että kussakin sävelmässä olisi ainakin yksi tunnuslukujen kannalta keskeinen ominaisuus. Kussakin sävelmässä tarkastellaan erikseen kutakin kahdeksaa tunnuslukua. Tässä yhteydessä ei tarkemmin pohdita toisintojoukon ominaisuuksien tai tahtitoisintojen eroavuuksien syitä.

Sävelmä n:o 44 (katso nuottiliitteet artikkelin lopusta) on esimerkkinä toisintojoukosta, jossa on vain vähän poikkeavuustahteja ja jossa tahtitoisinnot keskittyvät tiettyyn toisintoon.

Kuva 18. Sävelmässä n:o 44 olevien poikkeavuustahtien määrä ja tahtitoisintojen frekvenssit.

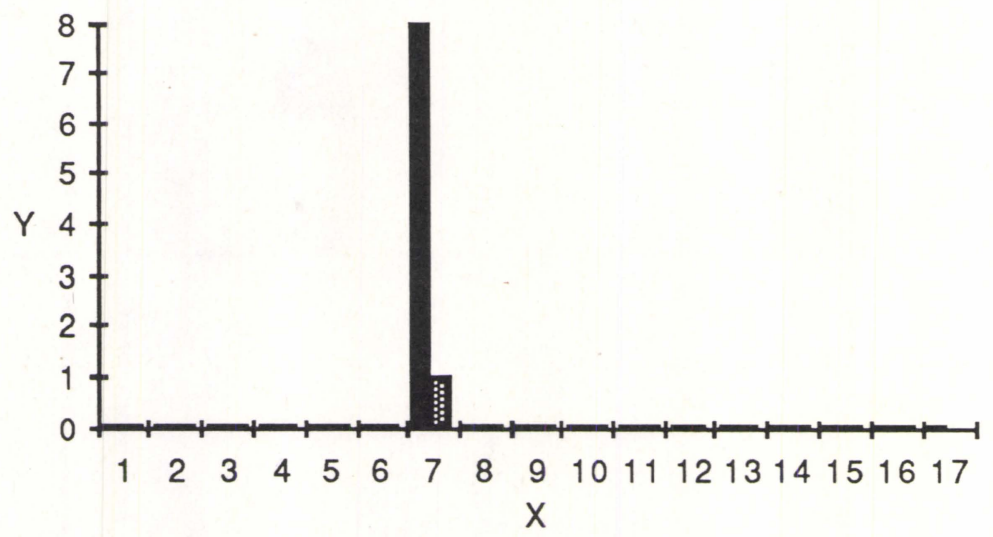

Sävelmää n:o 44 käytetään vain virren 189 yhteydessä. Tutkimusmateriaalissa sävelmästä on kahdeksan toisintoa kuudelta veisaajalta. 
Sävelmän yhtenäisyyskerroin $Y^{s}$ : Sävelmästä tavataan vain yksi poikkeavuustahti (tahti 7). Sävelmän yhtenäisyyskerroin on näin ollen alhainen $\left(Y^{\mathbf{s}}=\right.$ $0,06)$.

Toisintojoukon yhtenäisyyskerroin $\mathrm{Y}^{\mathrm{t}}$ : Sävelmän ainoassa poikkeavuustahdissa on vain kaksi tahtitoisintoa, joten myös toisintojoukon yhtenäisyyskerroin on alhainen $\left(\mathrm{Y}^{\mathrm{t}}=0,02\right)$.

Poikkeavuustahtien suhteellinen frekvenssi $\mathrm{Pp} / \mathrm{t}$ : Veisaajia on kaiken kaikkiaan kahdeksan ja tahtitoisintoja on vain kaksi, joten myös poikkeavuustahtien suhteellinen frekvenssi on alhainen $\left(\mathrm{P}^{\mathrm{p} / \mathrm{t}}=0,25\right)$.

Kuva 19. Sävelmän n:o 44 poikkeavuustahtien määrä suhteessa toisintojen kokonaismäärään.

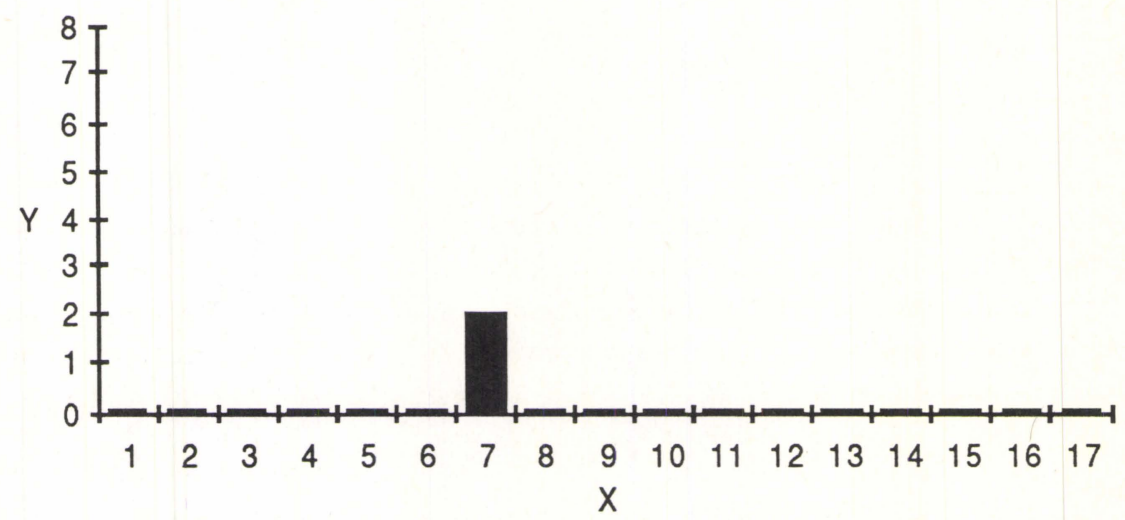

Poikkeavuustahtien yhtenäisyyskerroin $Y^{\mathrm{P}}$ : Poikkeavuustahteja ei ole sävelmässä kuin yksi, joten hajonnan tutkimisella ei tässä tapauksessa ole mieltä $\left(Y^{\mathrm{P}}=0\right)$.

Valtatoisintojen suhteellinen keskiarvo $\mathrm{V}^{\text {av/t }}$ : Tahtitoisinnot keskittyvät toisintojoukossa selvästi toiseen kahdesta muodosta: sitä käyttävät kaikki kahdeksan veisaajaa $\left(\mathrm{V}^{\text {av/t }}=1\right)$.

Valtatoisintojen yhtenäisyyskerroin $\mathrm{Y}^{\mathbf{v}}$ : Myös poikkeavuustahdeissa olevien maksimitahtitoisintojen frekvenssin hajonta on nolla $\left(\mathrm{Y}^{\mathbf{v}}=0\right)$.

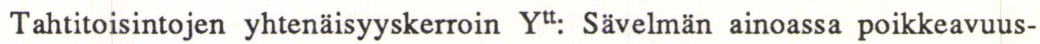
tahdissa on hajonta suuri $(s t=5)$. Toista muotoa käyttää vain yksi veisaaja, mutta koska tunnusluku kuvaa poikkeavuustahtien keskinäistä tahtitoisintojen frekvenssin hajontaa ja sävelmässä on poikkeavuustahteja vain yksi, on tahtitoisintojen frekvenssien hajonta nolla $\left(\mathrm{Y}^{\mathrm{tt}}=0\right)$. 
Kuva 20. Sävelmän n:o 44 tahtitoisintojen frekvenssien hajonta.

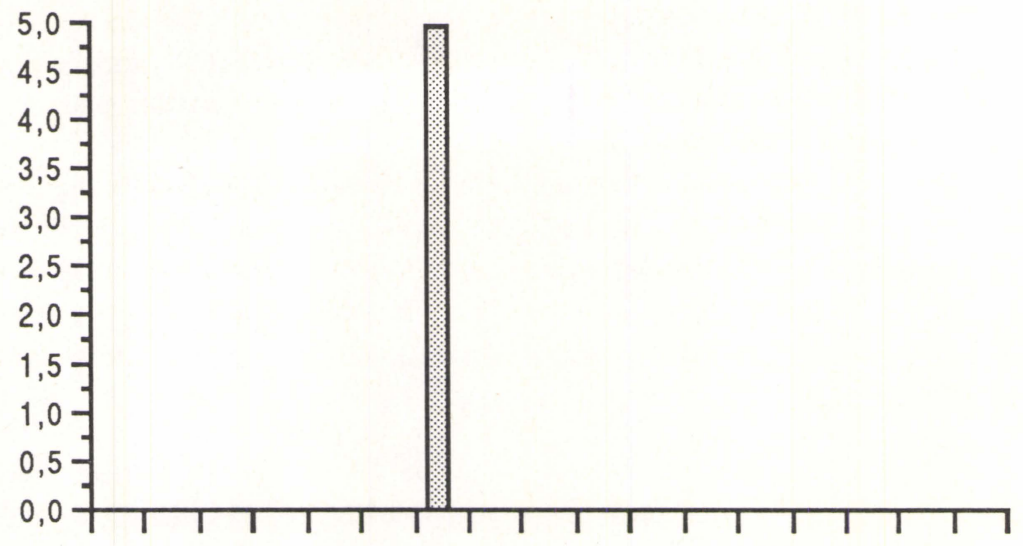

Poikkeavuustahtien sijainti Psi: Poikkeavuustahti sijaitsee toisen säkeen loppupuolella.

Sävelmä n:o 17 on esimerkkinä toisintojoukosta, jossa on runsaasti poikkeavuustahteja. Toisintojoukko on silti sangen yhtenäinen, sillä valtatoisinnoista erottuvia tahtitoisintoja tavataan vain muutamalta veisaajalta ja lisäksi eroavuudet koskevat vain hajasäveliä.

Kuva 21. Sävelmässä n:o 17 olevien poikkeavuustahtien määrä ja tahtitoisintojen frekvenssit.

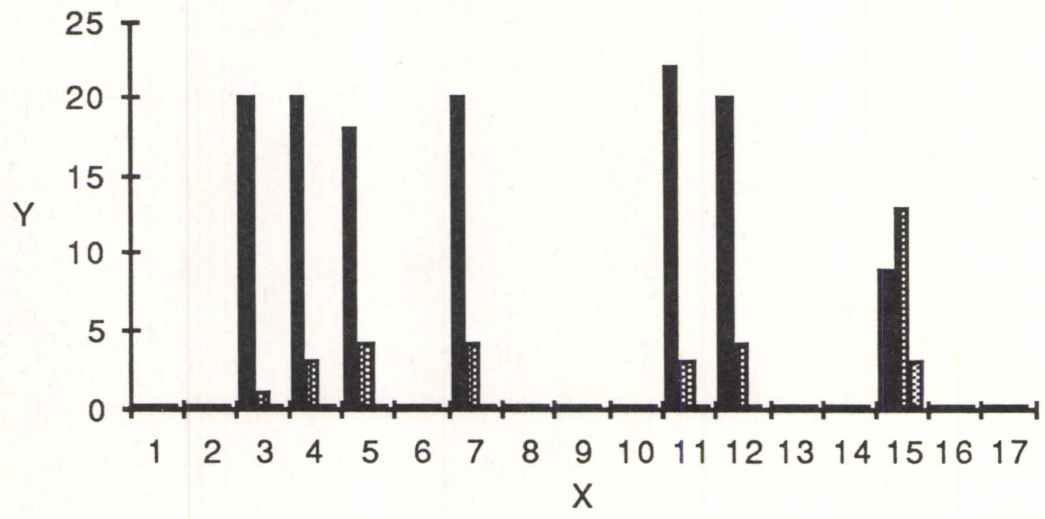

Sävelmää n:o 17 tavataan sekä HSHL:n 65, 111, 156 että 186:n yhteydessä. Toisintoja on kaksikymmentäviisi ja veisaajia yhdeksän.

Sävelmän yhtenäisyyskerroin $Y^{s}$ : Sävelmässä on sen pituuteen nähden selvästi enemmän poikkeavuustahteja kuin edellisessä sävelmässä. Tahteja on 17 ja niistä alle puolet (7) on poikkeavuustahteja $\left(Y^{s}=0,41\right)$ 
Toisintojoukon yhtenäisyyskerroin $\mathrm{Y}^{\mathrm{t}}$ : Poikkeavuustahdeissa on keskimäärin kaksi tahtitoisintoa, joten toisintojoukon yhtenäisyyskerroin on melko alhainen $\left(\mathrm{Y}^{\mathrm{t}}=0,04\right)$.

Poikkeavuustahtien suhteellinen frekvenssi Pp/t: Poikkeavuustahdeissa on keskimäärin kaksi tahtitoisintoa ja toisintoja on runsaasti (25), joten poikkeavuustahtien suhteellinen frekvenssi on alhainen $\left(\mathrm{Pp}^{\mathrm{t}} \mathrm{t}=0,09\right)$.

Kuva 22. Sävelmän n:o 17 poikkeavuustahtien määrä suhteessa toisintojen kokonaismäärään.

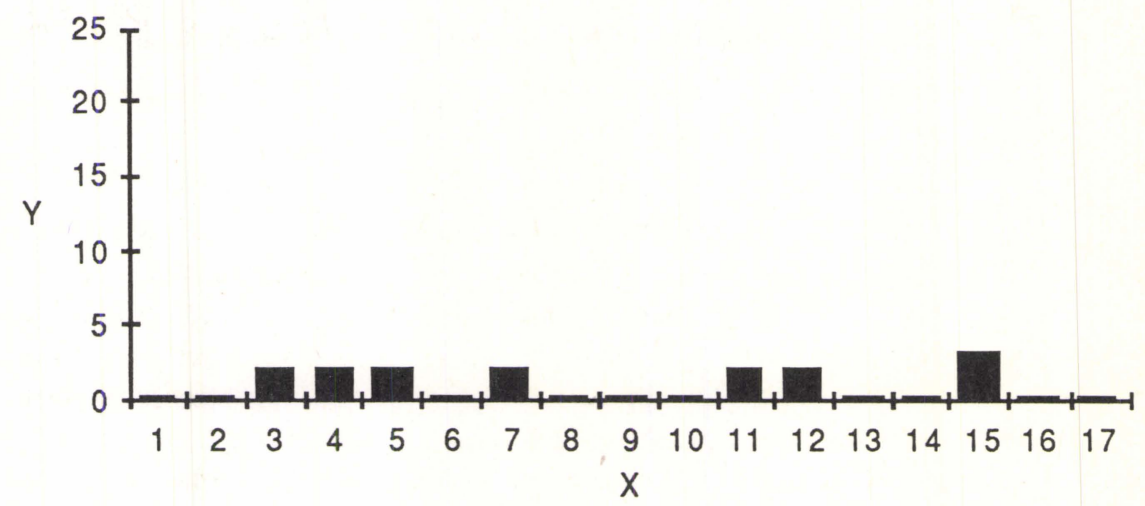

Poikkeavuustahtien yhtenäisyyskerroin $\mathrm{Y}^{\mathrm{P}}$ : Poikkeavuustahtien tahtitoisintojen lukumäärän hajonta ei ole suuri. Yleensä poikkeavuustahdeissa on kaksi erilaista muotoa. Vain tahdissa 15 on käytössä kolme tahtitoisintoa ( $\mathrm{Y}^{\mathrm{P}}=$ 0,38). Hajonta on esimerkkisävelmien toiseksi pienin.

Valtatoisintojen suhteellinen keskiarvo $\mathrm{V}^{\text {av/t}}$ : Poikkeavuustahtien maksimitoisintofrekvenssi on tahtia 15 lukuunottamatta korkea, eli suurimmassa osassa poikkeavuustahteja käyttävät veisaajat tiettyä valtatoisintoa $\left(V^{a v / t}=0,31\right)$.

Valtatoisintojen yhtenäisyyskerroin $\mathrm{Y}^{\mathrm{v}}$ : Tahdissa 15 on maksimitoisintofrekvenssi selvästi alhaisempi kuin muissa poikkeavuustahdeissa. Valtatoisintojen hajonta on suurempi kuin edellisessä sävelmässä ( $\left.Y^{\vee}=2,89\right)$.

Tahtitoisintojen yhtenäisyyskerroin $\mathrm{Y}^{\mathrm{tt}}$ : Tahtitoisintojen frekvenssien hajonta on tahtia 15 lukuunottamatta suuri. Kyseisen tahdin pieni hajonta aiheuttaa yhtenäi-syyskertoimen korkean arvon $\left(Y^{t t}=2,88\right)$. 
Kuva 23. Sävelmän n:o 17 tahtitoisintojen frekvenssien hajonta.

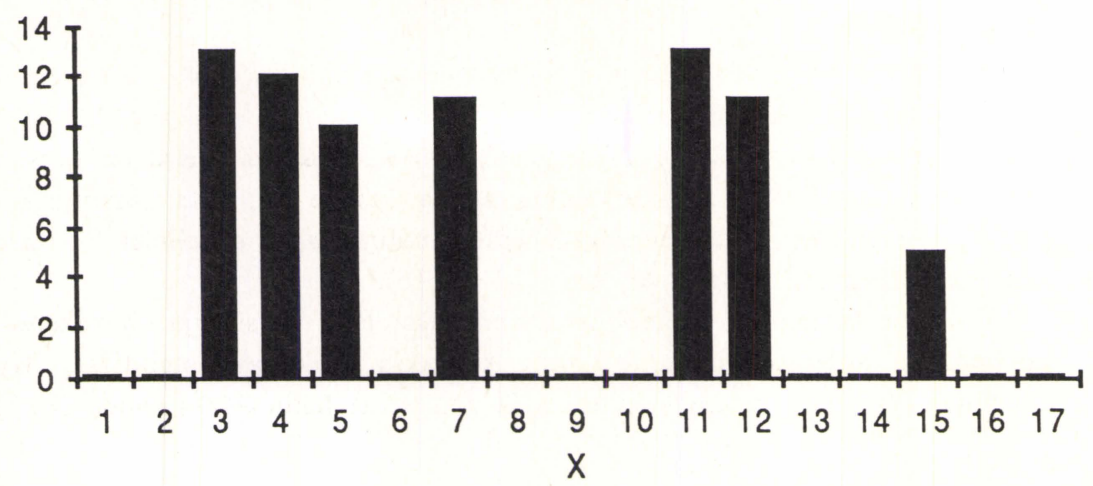

tahti 15

Poikkeavuustahtien sijainti Psi: Kaikissa säkeissä on toinen kokonainen tahti (tahdit 3,7,11 ja 15), ja molempien säeparien esisäkeitten kolmas ja neljäs tahti poikkeavuustahteja. Säkeitten alut ovat yhdenmukaisia.

Sävelmä n:o 187 on esimerkkinä toisintojoukosta, jolle on ominaista sekä poikkeavuustahtien että tahtitoisintojen suuri määrä: sävelmän kaikki tahdit ovat poikkeavuustahteja ja kussakin poikkeavuustahdissa on vähintään kaksi tahtitoisintoa. Lisäksi toisintojoukolle on tyypillistä se, että mitään tahtitoisinnoista ei tavata kaikista toisinnoista.

Kuva 24. Sävelmässä n:o 187 olevien poikkeavuustahtien määrä ja tahtitoisintojen frekvenssi.

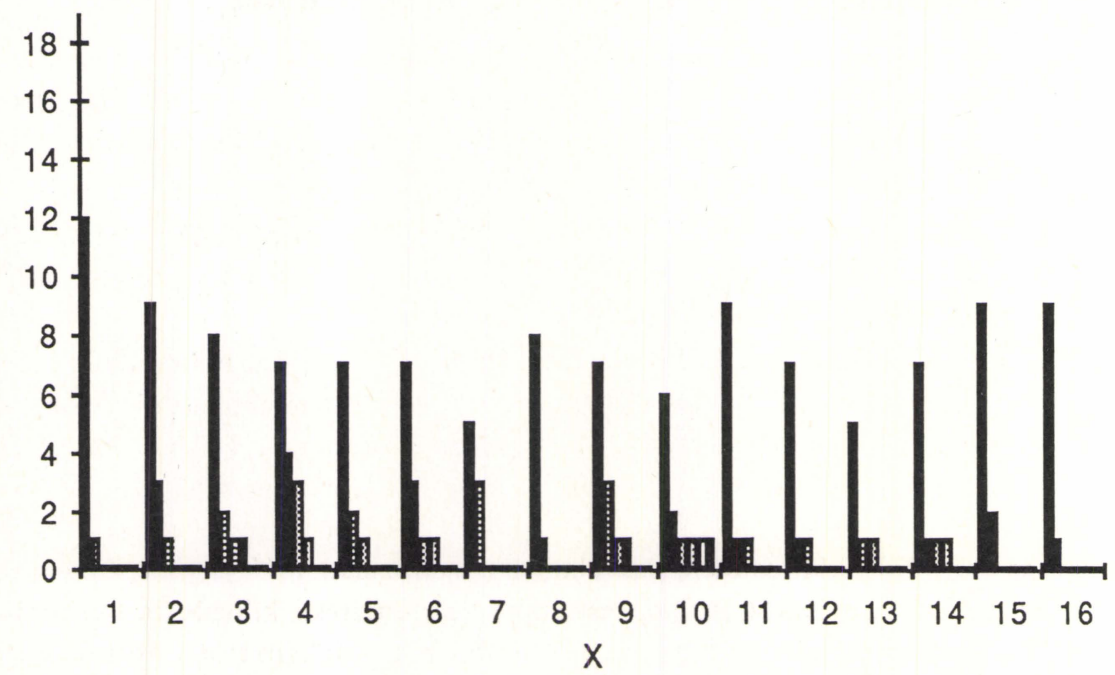


Sävelmää n:o 187 käytetään sekä HSHL:ssa 20, 91, 129 ja 181. Toisintoja on yhdeksäntoista ja veisaajia yhdeksän. Sävelmä on arkkivirren "Kreivin sylissä istunut" toisinto.

Sävelmän yhtenäisyyskerroin $Y^{s}$ : Sävelmän kaikki tahdit ovat poikkeavuustahteja, joten sävelmän yhtenäisyyskerroin saa arvon $1\left(Y^{s}=1\right)$.

Toisintojoukon yhtenäisyyskerroin $\mathrm{Y}^{\mathrm{t}}$ : Poikkeavuustahdeissa on runsaasti tahtitoisintoja. Yhtenäisyyskertoimen arvoa laskee se, että toisintoja on veisaajien määrään nähden runsaasti. Tästä huolimatta on sävelmän $\mathrm{Y}^{\mathrm{t}}$-kerroin esimerkkisävelmien toiseksi korkein $\left(\mathrm{Y}^{\mathrm{t}}=0,16\right)$.

Poikkeavuustahtien suhteellinen frekvenssi Pp/t: Toisintoja on kaksitoista ja tahtitoisintoja keskimäärin kolme kussakin poikkeavuustahdissa. Myös sävelmän $\mathrm{Y}^{\mathrm{P}}$-arvoa laskee toisintojen ja veisaajien lukumäärän suhde (ks. $\mathrm{Y}^{\mathrm{t}}$ ) $(\mathrm{Pp} / \mathrm{t}=0,17)$. Erityisesti tahdeissa $3,4,6,9,10$ ja 14 on runsaasti tahtitoisintoja.

Kuva 25. Sävelmän n:o 187 poikkeavuustahtien määrä suhteessa toisintojen kokonaismäärään.

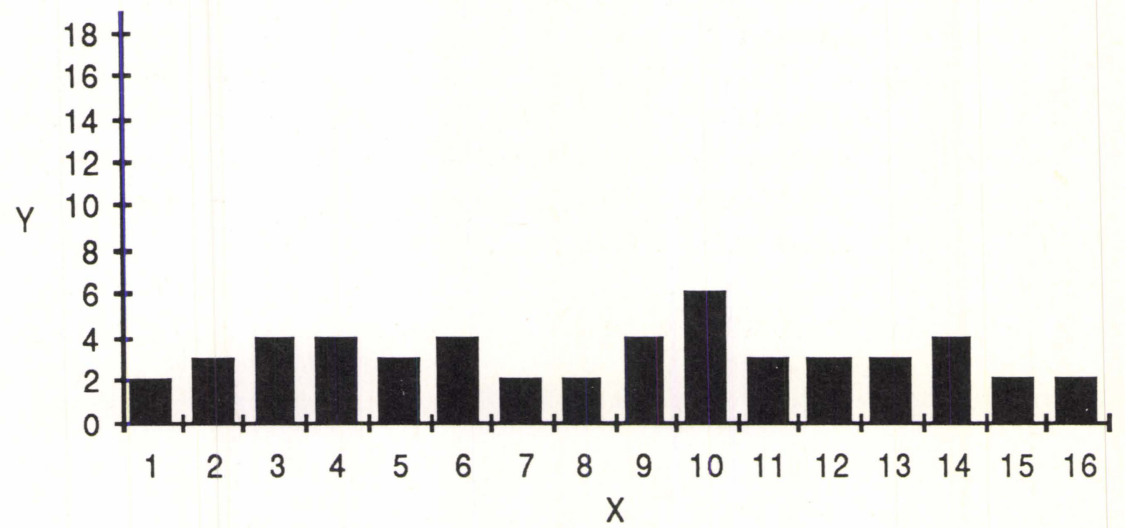

Poikkeavuustahtien yhtenäisyyskerroin $\mathrm{Y}^{\mathrm{P}}$ : Myös tahtitoisintojen lukumäärän hajonta on tässä sävelmässä suuri $\left(Y^{\mathrm{P}}=1,11\right)$. Erityisen kirjava on tahti 10 , josta on käytössä kuusi eri muotoa.

Valtatoisintojen suhteellinen keskiarvo $\mathrm{V}^{\text {av/t }}$ : Maksimitoisintofrekvenssi on keskimäärin kahdeksan. Kuvasta 24 voidaan huomata, että myös tässä sävelmässä on suurimmassa osassa poikkeavuustahteja löydettävissä valtatoisinto, mutta koska tahdeissa on tavallista runsaammin tahtitoisintoja, eikä ensimmäistä tahtia lukuunottamatta mitään toisintoa tavata kaikilta veisaajilta saa toisintojoukko esimerkkisävelmien matalimman $V^{\text {av/t }}$-arvon $\left(V^{\text {av } / t}=0,4\right)$. Erityisesti tahdeissa 4 ja 7 on useampia tasavertaisesti kilpailevia toisintoja.

Valtatoisintojen yhtenäisyyskerroin $\mathrm{Y}^{\mathrm{v}}$ : Maksimitoisintofrekvenssin hajonta ei ole kovinkaan suuri $\left(\mathrm{Y}^{\mathrm{v}}=1,75\right)$. Maksimitoisintofrekvenssi on keskimäärin kahdeksan. 
Tahtitoisintojen yhtenäisyyskerroin $\mathrm{Y}^{\mathrm{tt}}$ : Hajonta on keskimääräistä pienempi eli valtatoisinto ei erotu yhtä selvästi kuin muissa esimerkkisävelmissä $\left(Y^{t t}=1,60\right)$. Suurin hajonta on sävelmän alussa (tahti 1$)$, jossa toista tahtitoisinnon muotoa käyttää vain yksi veisaaja.

Kuva 26. Sävelmän n:o 187 tahtitoisintojen frekvenssien hajonta.

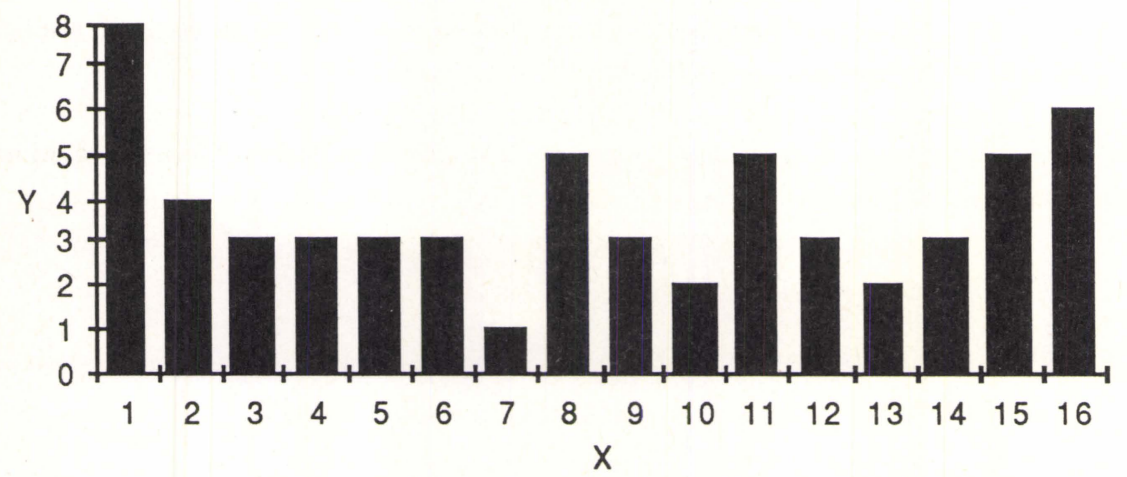

Poikkeavuustahtien sijainti $\mathrm{P}^{\text {si: }}$ Yhtenäisimmät tahdit ovat sävelmän alussa ja lopussa sekä esisäeparin lopussa. Näissä kohdissa on vain kaksi tahtitoisintoa ja niistä toista käyttää vain yksi veisaaja. Ensimmäistä säettä lukuunottamatta on tahtitoisintoja eniten säkeitten alkupuolella. Samoin tahtitoisintojen frekvenssi näyttää olevan säkeitten alkupuolella korkeampi kuin loppupuolella.

Sävelmä n:o 193 on esimerkkinä toisintojoukosta, jossa on runsaasti poikkeavuustahteja, mutta jota voidaan tästä huolimatta pitää yhtenäisenä: tahtitoisintoja on poikkeavuustahdeissa vähän ja niitten frekvenssi on matala, lisäksi poikkeavuudet koskevat yhtä poikkeavuustahtia lukuunottamatta vain hajasäveliä.

Kuva 27. Sävelmässä n:o 193 olevien poikkeavuustahtien määrä ja tahtitoisintojen frekvenssit.

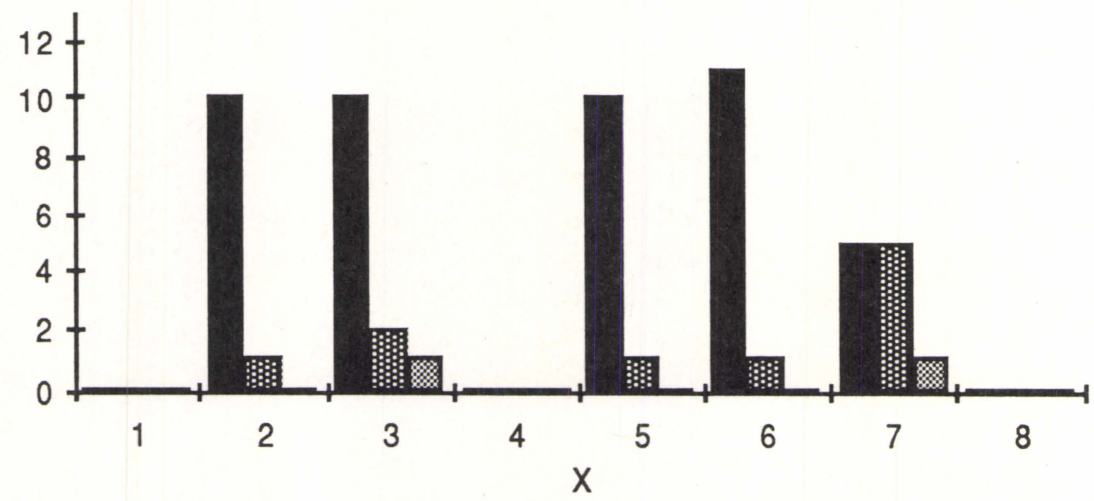


Sävelmää käytetään tavallisesti HSHL:ssa 93, mutta yksi veisaaja käyttää sitä HSHL:ssa 54. Toisintoja on kolmetoista ja veisaajia kymmenen.

Sävelmän yhtenäisyyskerroin $Y^{s}$ : Sävelmän tahdeista yli puolet on poikkeavuustahteja, joten sävelmän yhtenäisyyskerroin on korkea $\left(Y^{s}=0,63\right)$

Toisintojoukon yhtenäisyyskerroin $\mathrm{Y}^{\mathrm{t}}$ : Toisintojoukon yhtenäisyyskerroin on melko korkea, sillä suuri osa tahdeista on poikkeavuustahteja ja niistä lähes puolessa on kolme tahtitoisintoa $\left(\mathrm{Y}^{\mathrm{t}}=0,12\right)$.

Poikkeavuustahtien suhteellinen frekvenssi $\mathrm{Pp} / \mathrm{t}$ : Suhteessa toisintojen määrään on tahtitoisintoja vähän $(\mathrm{P} / \mathrm{t}=0,18)$.

Kuva 28. Sävelmän n:o 193 poikkeavuustahtien määrä suhteessa sävelmän toisintojen kokonaismäärään.

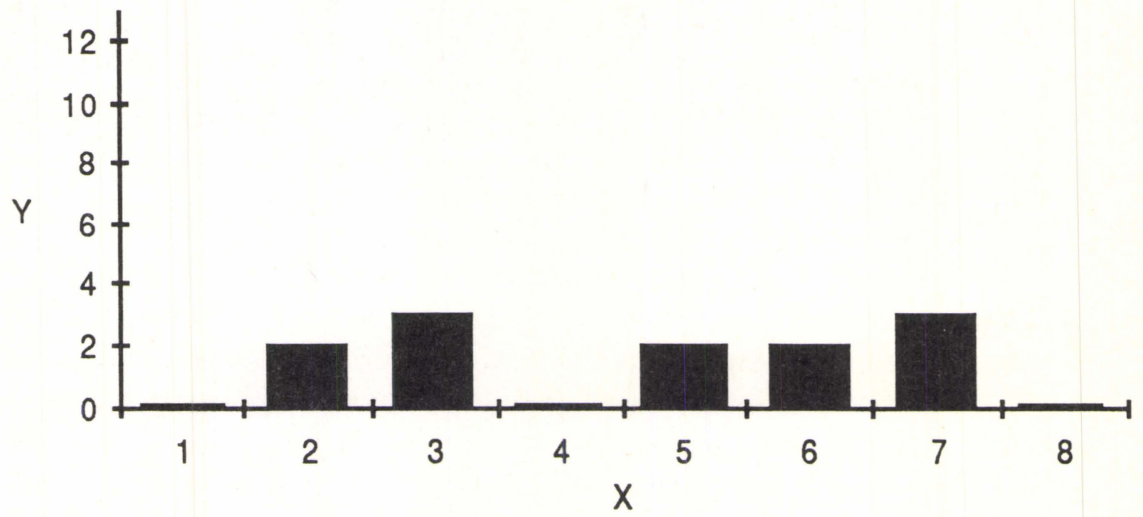

Poikkeavuustahtien yhtenäisyyskerroin $\mathrm{Y}^{\mathrm{P}}$ : Tahtitoisintojen määrä poikkeavuusvuustahdeissa vaihtelee kahdesta kolmeen. Hajonta on esimerkkisävelmien toiseksi matalin $\left(\mathrm{Y}^{\mathrm{P}}=0,55\right)$.

Valtatoisintojen suhteellinen keskiarvo $\mathrm{V}^{\text {av/t }}$ : Valtatoisintojen keskiarvo on lähellä toisintojen kokonaismäärää (keskiarvo $=9,60$ ), joten poikkeavuustahdeissa on ainakin yksi toisinto, jota lähes kaikki veisaajat käyttävät $\left(\mathrm{V}^{\mathrm{av} / \mathrm{t}}=0,71\right)$.

Valtatoisintojen yhtenäisyyskerroin $\mathrm{Y}^{\mathbf{v}}$ : Maksimitoisintofrekvenssin hajonta on sävelmän alkupuolella pieni, mutta seitsemäs tahti erottuu joukosta matalalla maksimifrekvenssillä. Kuvasta 27 huomataan, että tässä tahdissa on kaksi yhtä yleistä toisintoa $\left(\mathrm{Y}^{\mathbf{v}}=2,39\right)$.

Tahtitoisintojen yhtenäisyyskerroin $\mathrm{Y}^{\mathrm{tt}}$ : Tahtitoisintojen frekvenssin hajonta on esimerkkisävelmien toiseksi suurin $\left(Y^{\mathrm{tt}}=1,90\right)$. Tämä johtuu seitsemännestä tahdista, jossa hajonta on kahden yhtä yleisen tahtitoisinnon johdosta matala. 
Kuva 29. Sävelmän n:o 193 tahtitoisintojen frekvenssien hajonta.

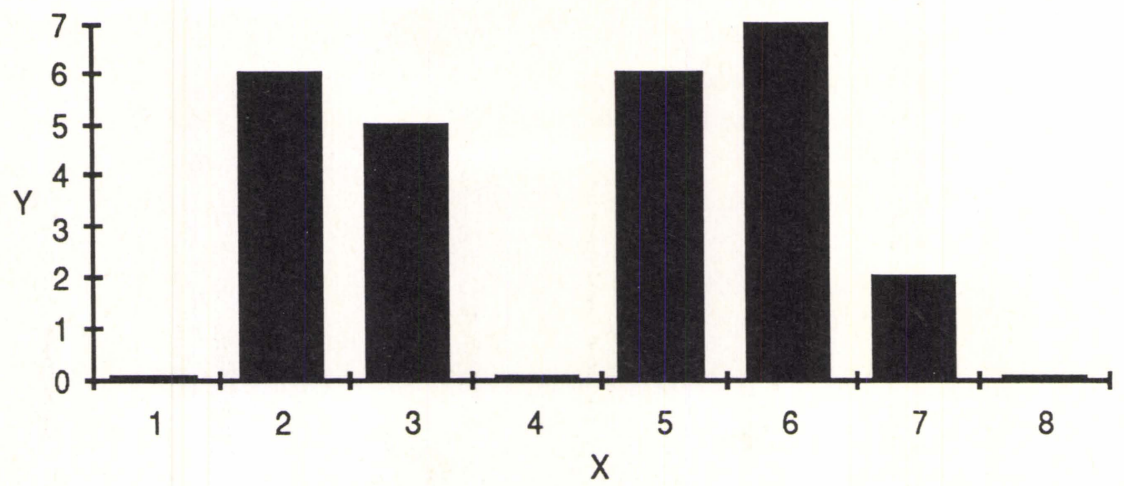

tahti 7

Poikkeavuustahtien sijainti Psi: Säkeiden alut ja loput ovat toisintojoukossa yhtenäisiä. Toisen säkeen alussa on yksi poikkeava muoto. Se tavataan 1950luvulla tallennettujen toisintojen joukosta.

Vertailemalla kuvia 187 ja 193 huomataan, ettei sävelmän yhtenäisyyskertoimesta ole syytä tehdä päätelmiä, ellei samalla ole tiedossa poikkeavuustahtien tahtitoisintojen määrä. Molemmissa toisintojoukoissa on sävelmän yhtenäisyyskerroin korkea eli lähes kaikissa tahdeissa on poikkeavuutta toisintojen välillä. Tahtitoisintojen keskimääräinen määrä on sen sijaan sävelmässä 187 selvästi korkeampi kuin sävelmässä 193. Jos lisäksi vertailtaisiin runkosäveliä huomattaisiin, että sävelmän 193 toisintojoukko on täysin yhtenäinen kun taas sävelmän 187 toisinnot poikkeavat toisistaan myös runkosäveliltään.

Sävelmä n:o $29 \mathrm{~b}$ on esimerkkinä toisintojoukosta, jossa poikkevuustahteja on suhteellisen vähän sävelmän pituuteen nähden, mutta jossa on kussakin poikkeavuustahdissa useita tahtitoisintoja. 
Kuva 30. Sävelmässä n:o 29 olevien poikkeavuustahtien määrä ja tahtitoisintojen frekvenssit.

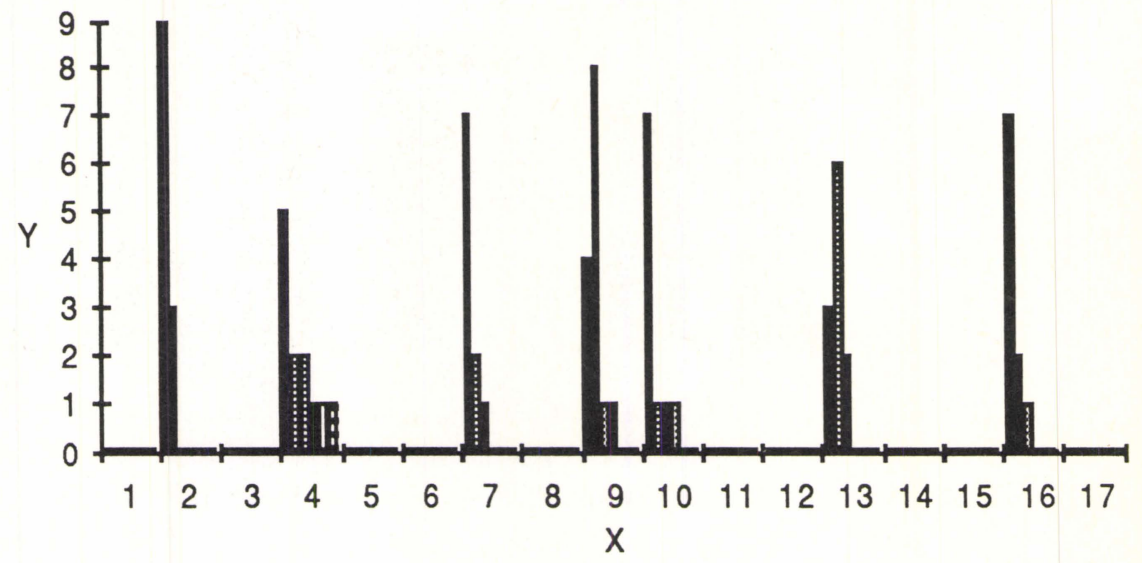

Sävelmää n:o 29b käytetään vain HSHL:ssa 106. Toisintoja ja veisaajia on yhdeksän.

Sävelmän yhtenäisyyskerroin $Y^{s}$ : Poikkeavuustahteja on seitsemän eli noin kolmannes sävelmän tahdeista $\left(Y^{\mathbf{s}}=0,41\right)$.

Toisintojoukon yhtenäisyyskerroin $\mathrm{Y}^{\mathrm{t}}$ : Poikkeavuustahdeissa on enemmän tahtitoisintoja kuin useimmissa muissa tarkasteltavina olevissa sävelmissä $\left(\mathrm{Y}^{\mathrm{t}}\right.$ $=0,17)$. Toisintojoukon yhtenäisyyskerroin on esimerkkisävelmien toiseksi korkein.

Poikkeavuustahtien suhteellinen keskiarvo $\mathrm{P}^{\mathrm{p} / \mathrm{t}}$ : Tahtitoisintojen lukumäärä suhteessa toisintojen kokonaismäärään on esimerkkisävelmien korkein $\left(\mathrm{P}^{\mathrm{p} / \mathrm{t}}=\right.$ $0,41)$. Esimerkiksi tahdista 4 on yhdeksästä veisaajasta peräti kuudella erilainen muoto.

Kuva 31. Sävelmässä n:o $29 \mathrm{~b}$ olevien poikkeavuustahtien määrä ja tahtitoisintojen frekvenssit.

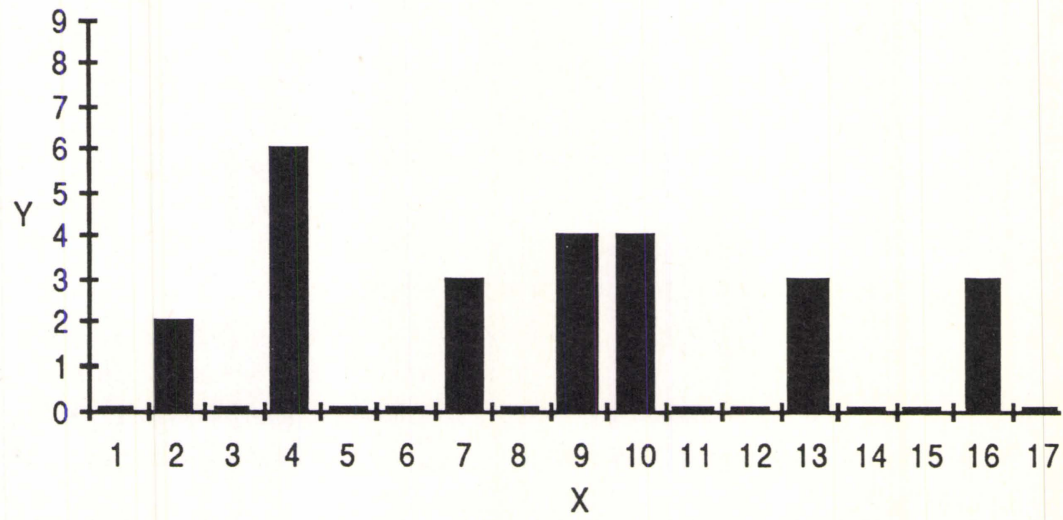


Poikkeavuustahtien yhtenäisyyskerroin YP: Myös tahtitoisintojen lukumäärän hajonta on suuri $\left(Y^{\mathrm{P}}=1,25\right)$.

Valtatoisintojen suhteellinen keskiarvo $\mathrm{V}^{\text {av/t }}$ : Maksimitoisintofrekvenssin suhteellinen keskiarvo on esimerkkisävelmien toiseksi korkein $\left(\mathrm{V}^{\mathrm{av} / \mathrm{t}}=0,78\right)$. Useimmissa poikkeavuustahdeissa tavataan toisinto, jota lähes kaikki veisaajat käyttävät.

Valtatoisintojen yhtenäisyyskerroin $\mathrm{Y}^{\mathrm{v}}$ : Maksimitoisintofrekvenssien hajonta ei ole suuri $\left(Y^{v}=1,29\right)$. Tämä merkitsee sitä, että valtatoisinnot tavataan poikkeavuustahdeissa lähes yhtä monesta toisinnosta.

Tahtitoisintojen yhtenäisyyskerroin $\mathrm{Y}^{\mathrm{tt}}$ : Tahtitoisintojen frekvenssin hajonta on keskimääräistä matalampi $\left(Y^{t t}=0,88\right)$ eli poikkeavuustahdeissa on keskimääräistä enemmän keskenään kilpailevia valtatoisintoja. Erityisesti tahdeissa neljä ja kolmetoista on useita yleisesti käytössä olevia tahtitoisintoja.

Kuva 32. Sävelmän n:o $29 \mathrm{~b}$ tahtitoisintojen frekvenssien hajonta.

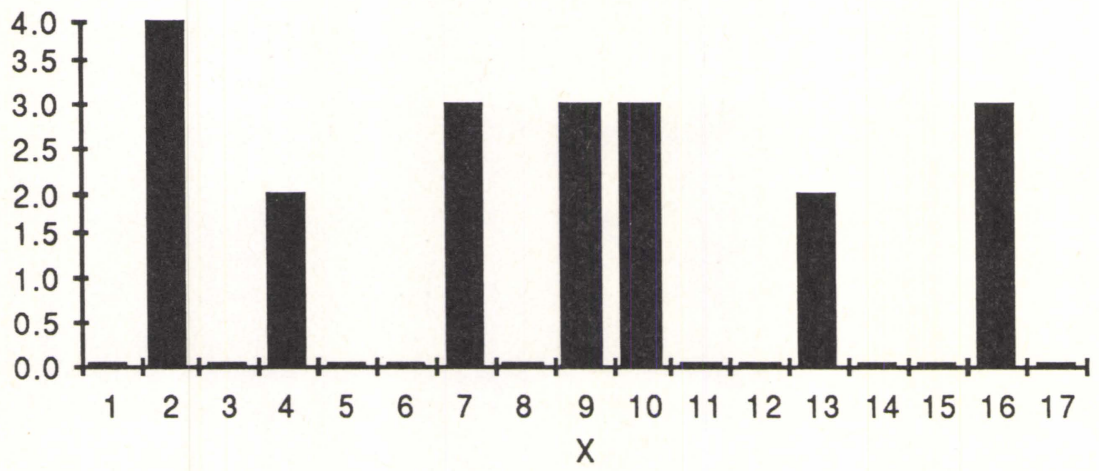

Poikkeavuustahtien sijainti $\mathrm{P}^{\text {si: }}$ Toisintojoukossa kiinnittyy huomio siihen, että poikkeavuustahdit sijaitsevat säerakenteen kannalta samoissa kohdissa: säerajoilla. Poikkeavuudet ovat joko säkeen alussa yleensä toisessa tahdissa tai säkeen lopussa yleensä toiseksi viimeisessä tahdissa. Logiikka näyttää olevan se, että poikkeavuudet sijoittuvat säeparien keskelle eli esisäkeen viimeiselle tahdille ja jälkisäkeen toiseksi viimeiselle tahdille. Ainoan poikkeuksen muodostaa sävelmän toinen tahti. Muista poikkeavaa muotoa tavataan vain 1950-luvulla tallennetuista Ester Laaksosen ja Fiina Jalavan toisinnoista. Ester Laaksonen käyttää tahtitoisintoa vain säkeen kertauksessa.

On mahdollista, että sävelmän toisessa tahdissa on kyse 1950-luvulla syrjäytymässä olevasta muodosta. Kenties sävelmien yhdenmukaistuminen noudattaa tiettyjä lainalaisuuksia, kuten sellaista, että sävelmän taitekohdissa olevat poikkeavuudet yhtenäistyvät viimeiseksi. Jos kuvaan 29 otetaan mukaan vain 1960-luvulla ja sitä myöhemmin tallennetut toisinnot, noudattaisi poikkevuuksien sijainti tarkasti edellä mainittua säerakenteeseen liittyvää logiikkaa. Yleispätevämpänä kuin säerakenteeseen liittyvänä selityksenä voisi olla se, että sävelmän yhdenmukaistuminen liittyy paradigman sijaintiin joko 
painollisilla tai painottomilla sävelmän osilla, paradigman musiikillisiin ominaisuuksiin ja sen yleisyyteen.

Sävelmä n:o 2 on esimerkkinä toisintojoukosta, jossa lähes kaikki tahdit ovat poikkeavuustahteja, mutta niissä olevien tahtititoisintojen lukumäärä on lähes sama. Toisintoja on kaksitoista ja veisaajia yksitoista.

Kuva 33. Sävelmässä n:o 2 olevien poikkeavuustahtien määrä ja tahtitoisintojen frekvenssit.

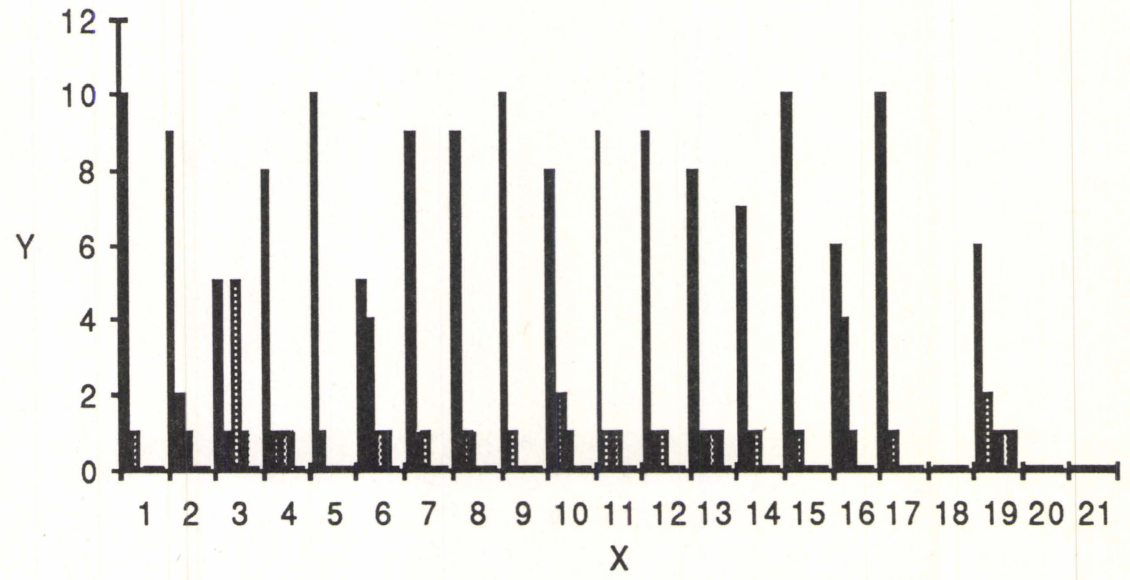

Sävelmän yhtenäisyyskerroin $Y^{s}$ : Sävelmän 21 tahdista on 18 poikkeavuustahteja $\left(Y^{\mathbf{s}}=0,86\right)$. Sävelmän yhtenäisyyskerroin on esimerkkisävelmien toiseksi korkein.

Toisintojoukon yhtenäisyyskerroin $\mathrm{Y}^{\mathrm{t}}$ : Toisintojoukossa on esimerkkisävelmistä kaikkein eniten tahtitoisintoja. Suurimmassa osassa poikkeavuustahteja on kolme tai useampi tahtitoisinto $\left(\mathrm{Y}^{\mathrm{t}}=0,22\right)$.

Poikkeavuustahtien suhteellinen frekvenssi $\mathrm{Pp} / \mathrm{t}$ : Suhteessa toisintojen määrään ( $(\mathrm{tf}=12$ ) ei tahtitoisintoja ole erityisen runsaasti $(\mathrm{Pp} / \mathrm{t}=0,25)$. 
Kuva 34. Sävelmän n:o 2 poikkeavuustahtien määrä suhteessa toisintojen kokonaismäärään.

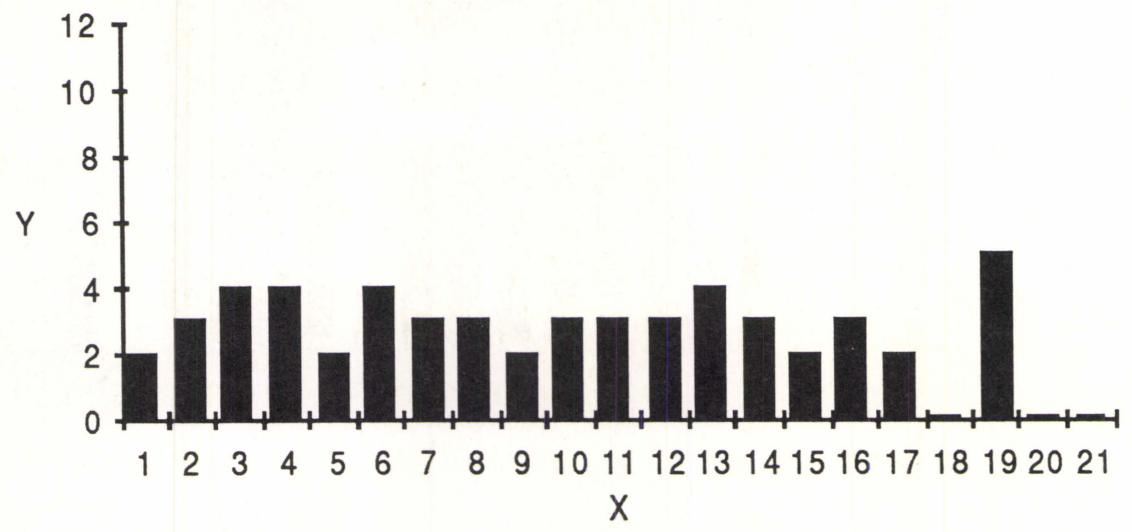

Poikkeavuustahtien yhtenäisyyskerroin $\mathrm{Y}^{\mathrm{P}}$ : Tahtitoisintojen lukumäärän hajonta ei ole suuri eli sävelmän kaikissa poikkeavuustahdeissa on varsin runsaasti tahtitoisintoja ( $\left.\mathrm{Y}^{\mathrm{P}}=0,87\right)$.

Valtatoisintojen suhteellinen keskiarvo $\mathrm{V}^{\text {av/t}}$ : Suurimmassa osassa poikkeavuustahteja on maksimitoisintofrekvenssi sama kuin toisintojen kokonaismäärä, mutta tahtien 3, 616 ja 19 matalat frekvenssit pudottavat keskiarvoa $\left(\mathrm{V}^{\mathrm{av} / \mathrm{t}}=0,69\right)$.

Valtatoisintojen yhtenäisyyskerroin $\mathrm{Y}^{\mathrm{v}}$ : Vain muutamissa tahdeissa (tahdit $3,6,16$ ja 19) on matala maksimitoisintofrekvenssi. Muissa tahdeissa tavataan toisinto, jota käyttävät lähes kaikki veisaajat $\left(\mathrm{Y}^{\mathbf{v}}=1,73\right)$.

Tahtitoisintojen yhtenäisyyskerroin $\mathrm{Y}^{\mathrm{tt}}$ : Tahtitoisintojen frekvenssien hajonta on varsin matala $\left(\mathrm{Y}^{\mathrm{tt}}=1,55\right)$. Kuvasta 33 huomataan, että hajontakuvio on suurimmassa osassa sävelmiä sama: poikkeavuustahdeissa on useita matalafrekvenssisiä toisintoja. Nämä johtuvat yhden veisaajan käyttämistä "virhetoisinnoista". 


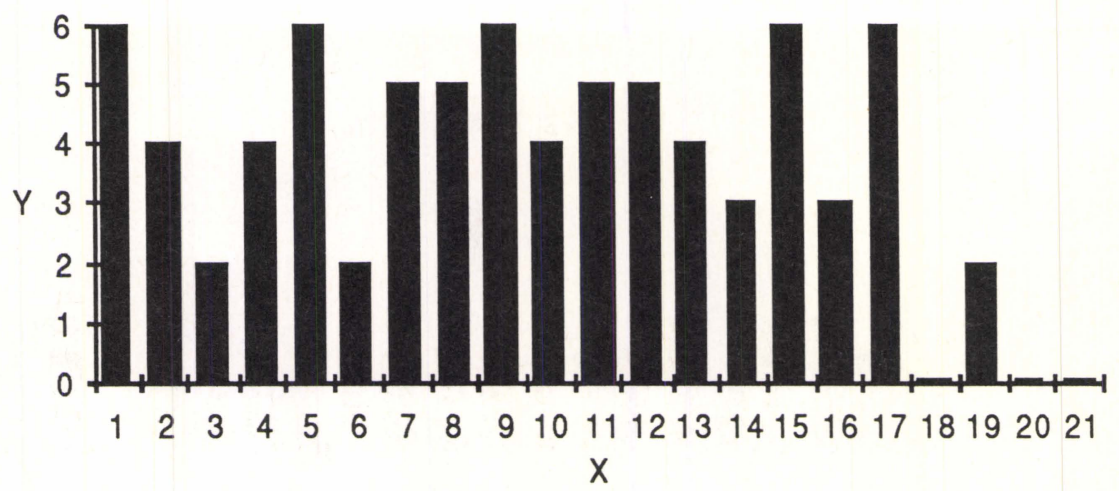

Toisintojoukossa erottuu kaksi tahtitoisintojen frekvenssiryhmää: ensimmäisessä ryhmässä tahtitoisintojen frekvenssi on lähes yhtä suuri kuin veisaajien määrä, toisessa ryhmässä frekvenssi on puolet veisaajien määrästä (tahdit 3, 6 ja 19).

Toisintojoukossa kiinnittyy huomio lisäksi siihen edellä mainittuun seikkaan, että suurimmassa osassa poikkeavuustahteja on yksi tai useampi tahtitoisinto jota käyttää vain yksi veisaaja. Vain viimeisessä säkeessä on muutama täysin yhdenmukainen tahti.

Tarkasteltaessa toisintojen nuottikuvaa huomataan, että yksi toisinnoista poikkeaa täysin muista toisinnoista. Poikkeavassa toisinnossa käytetään sävelmää n:o. Vasta ensimmäisen säkeistön lopussa siirtyy veisaaja käyttämään samaa sävelmää kuin muut. Toisen säkeistön kaksi ensimmäistä säettä on jo hieman lähempänä valtatoisintoa. Kaksi viimeistä toisen säkeistön säettä ovat samat kuin muilla veisaajilla

Poikkeavuustahtien sijainti Psi: Poikkeavuustahdit sijoittuvat tasaisesti pitkin sävelmää, vain viimeisessä säkeessä on muutama täysin yhtenäinen tahti. Tämä johtuu siitä, että veisaaja, joka suurimman osan tahtitoisinnoista veisaa, ryhtyy viimeisessä säkeessä käyttämään samaa valtatoisintoa kuin muutkin veisaajat.

Sävelmä n:o 113 on esimerkkinä toisintojoukosta, jossa on poikkeavuustahteja runsaasti, ja yhdessä tahdissa on keskimääräistä enemmän keskenään kilpailevia tahtitoisintoja. 
Kuva 36. Sävelmässä n:o 113 olevien poikkeavuustahtien määrä ja tahtitoisintojen frekvenssit.

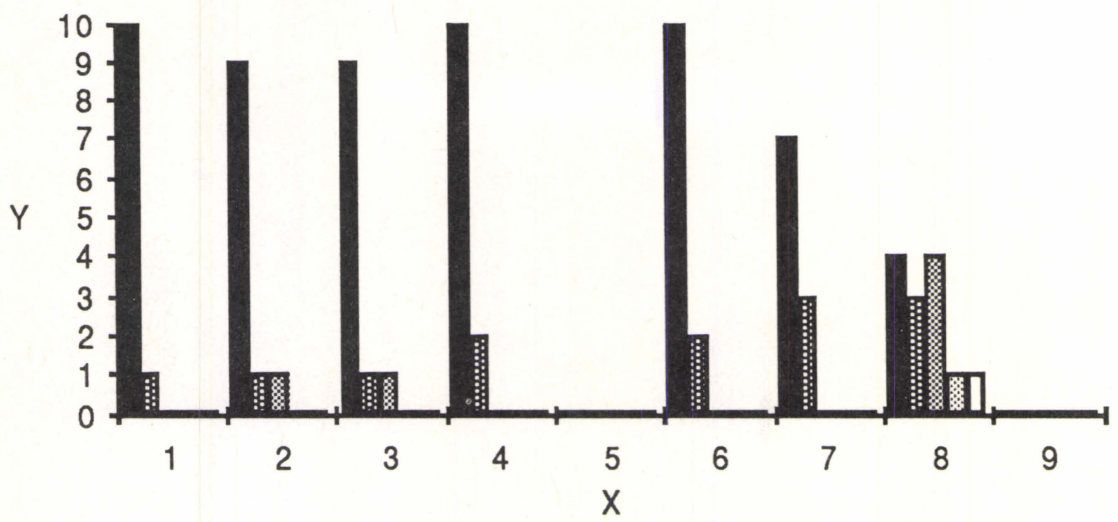

Sävelmässä n:o 113 on toisintoja kymmenen ja veisaajia yhdeksän. Sitä käytetään HSHL:ssa 69, 76, 90 ja 166.

Sävelmän yhtenäisyyskerroin $Y^{s}$ : Sävelmän yhdeksästä tahdista on seitsemän poikkeavuustahteja, joten yhtenäisyyskerroin saa korkean arvon ( $\mathrm{Y}^{\mathrm{s}}$ $=0,78)$.

Toisintojoukon yhtenäisyyskerroin $\mathrm{Y}^{\mathrm{t}}$ : Useimmissa tahdeissa on vain muutama poikkeavuustahti, mutta toiseksi viimeisessä tahdissa on peräti viisi tahtitoisintoa $\left(\mathrm{Y}^{\mathrm{t}}=0,21\right)$.

Poikkeavuustahtien suhteellinen frekvenssin $\mathrm{Pp} / \mathrm{t}$ : Poikkeavuustahteja on suhteessa toisintojen kokonaismäärän vähän $\left(\mathrm{P}^{\mathrm{p} / \mathrm{t}}=0,21\right)$. 
$K u v a$ 37. Sävelmän n:o 113 poikkeavuustahtien määrä suhteessa toisintojen kokonaismäärään.

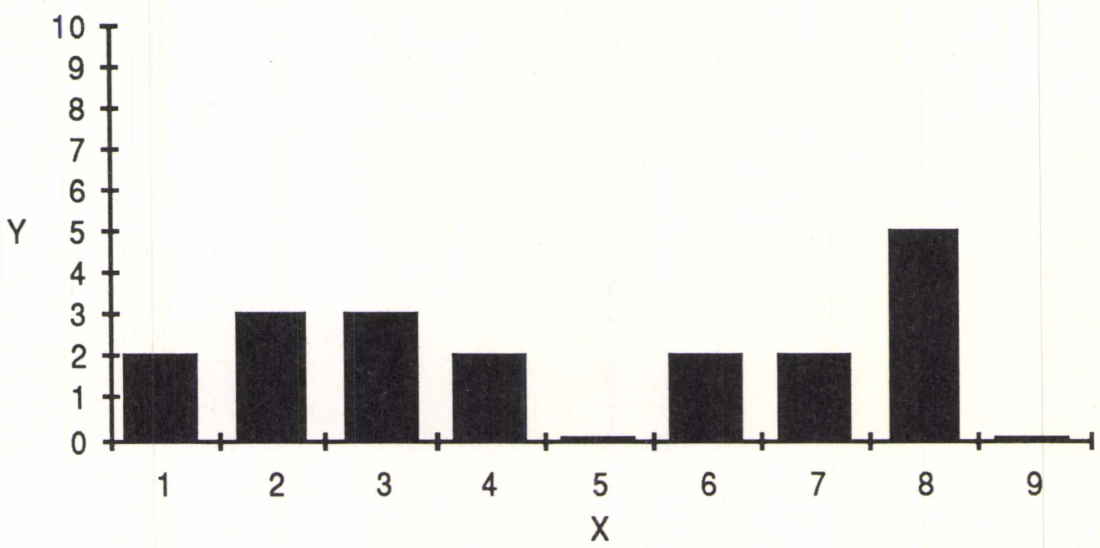

Poikkeavuustahtien yhtenäisyyskerroin Yp: Tahtitoisintojen lukumäärän hajonta on varsin suuri. Tämä johtuu ennen kaikkea tahdista kahdeksan, jossa on viisi tahtitoisintoa ( $\left.\mathrm{Y}^{\mathrm{P}}=1,11\right)$.

Valtatoisintojen suhteellinen keskiarvo $\mathrm{V}^{\text {av/t }}$ : Tahteja 7 ja 8 lukuunottamatta on poikkeavuustahtien maksimitoisintofrekvenssit lähes samat kuin toisintojen kokonaismäärä. Sävelmän suhteellinen keskiarvo onkin esimerkkisävelmien toiseksi korkein $\left(\mathrm{V}^{\mathrm{av} / \mathrm{t}}=0,84\right)$.

Valtatoisintojen yhtenäisyyskerroin $\mathrm{Y}^{\mathbf{v}}$ : Maksimitoisintofrekvenssin hajonta on esimerkkisävelmien suurin $\left(Y^{\mathbf{v}}=4,19\right)$. Tämä johtuu ennen kaikkea siitä, että tahdissa kahdeksan ei mikään toisinnoista ole saavuttanut selvää valtatoisinnon asemaa. Tässä tahdissa maksimitoisintofrekvenssi on kahdella toisinnolla. Kumpaakin niistä tavataan vain alle puolessa toisinnoista.

Tahtitoisintojen yhtenäisyyskerroin $\mathrm{Y}^{\mathrm{tt}}$ : Suurimmassa osassa poikkeavuustahteja erottuu yksi toisinto, joka on selvästi muita yleisempi. Tahtitoisintojen frekvenssin hajonta on matala tahdeissa seitsemän ja kahdeksan ( $\mathrm{Y}^{\mathrm{tt}}=$ $1,73)$. 
Kuva 38. Sävelmän n:o 113 tahtitoisintojen frekvenssien hajonta.

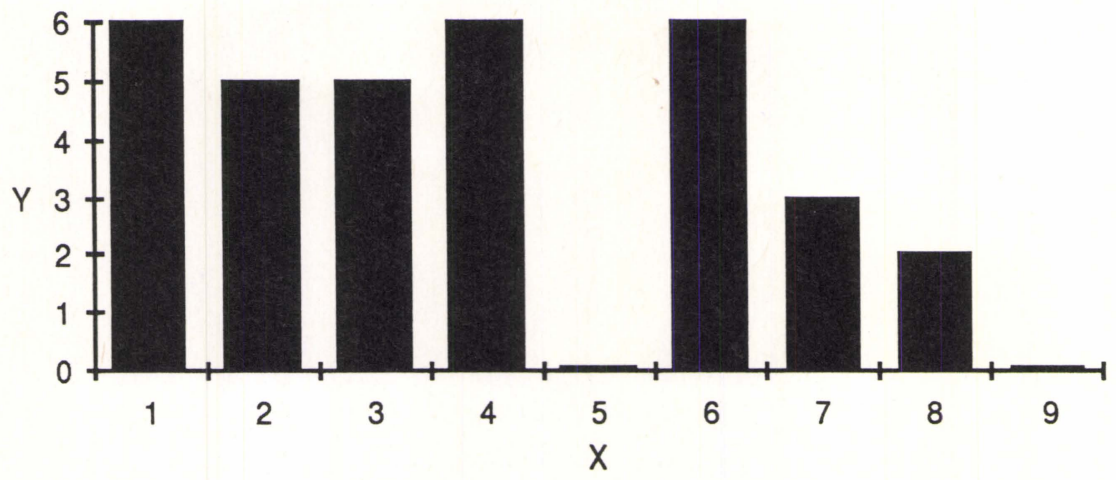

tahti $7 \quad 8$

Poikkeavuustahtien sijainti Psi: Poikkeavuustahdit sijoittuvat tasaisesti pitkin sävelmää. Vain säkeitten viimeiset tahdit (tahdit 5 ja 9) ovat täysin yhdenmukaisia.

Sävelmä n:o 97 on esimerkkinä toisintojoukosta, jossa on runsaasti yhtä yleisesti käytössä olevia tahtitoisintoja ja jossa poikkeavuudet sijoittuvat tiettyyn säkeeseen.

Kuva 39. Sävelmässä n:o 97 olevien poikkeavuustahtien määrä ja tahtitoisintojen frekvenssit.

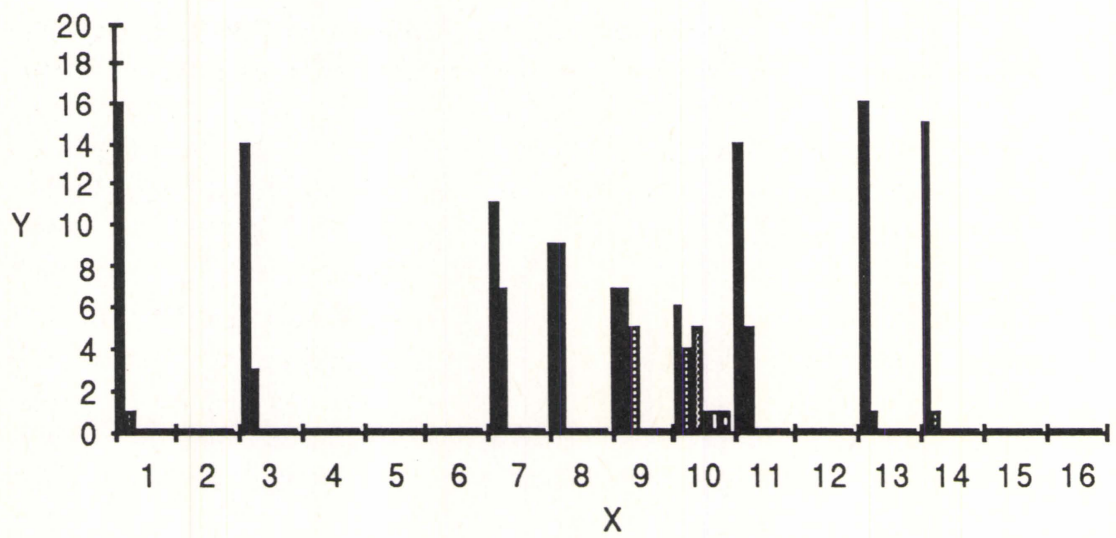

Sävelmää n:o 97 käytetään kahdeksassa HSHL:ssa: 119, 128, 130, 159, 162, 163, 175 ja 182. Toisintoja on kaksikymmentä ja veisaajia seitsemän.

Sävelmän yhtenäisyyskerroin $\mathrm{Y}^{\mathrm{s}}$ : Sävelmän tahdeista noin puolet on poikkeavuustahteja $\left(\mathrm{Y}^{\mathbf{s}}=0,56\right)$.

Toisintojoukon yhtenäisyyskerroin $\mathrm{Y}^{\mathrm{t}}$ : Toisintojoukossa on yhtä poikkeavuustahtia lukuunottamatta vain muutama tahtitoisinto $\left(\mathrm{Y}^{\mathrm{t}}=0,07\right)$. 
Poikkeavuustahtien suhteellinen frekvenssi $\mathrm{P}^{\mathrm{p} / \mathrm{t}}$ : Toisintojen lukumäärän nähden on tahtitoisintoja vähän $(\mathrm{P} / \mathrm{t}=0,13)$.

Kuva 40. Sävelmän n:o 97 poikkeavuustahtien määrä suhteessa toisintojen kokonaismäärään.

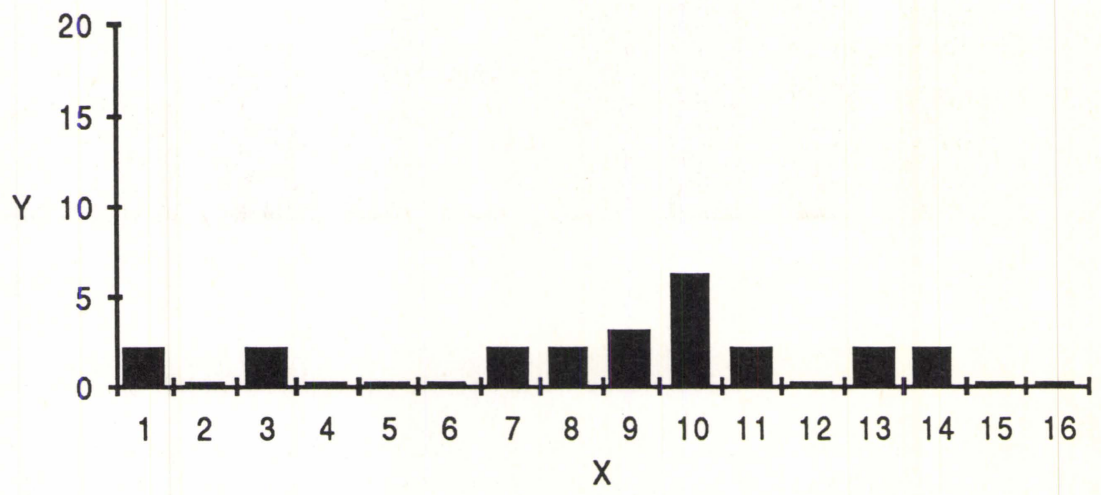

Poikkeavuustahtien yhtenäisyyskerroin $\mathrm{Y}^{\mathrm{P}}$ : Tahtitoisintojen lukumäärän hajonta on esimerkkisävelmien toiseksi suurin ( $\left.Y^{P}=1,33\right)$. Tämä johtuu tahdista 10 josta tavataan kuusi erilaista muotoa. Yleensä poikkeavuustahdeissa on vain kaksi tahtitoisintoa.

Valtatoisintojen suhteellinen keskiarvo $\mathrm{V}^{\text {av/t}}$ : Tahtitoisintojen maksimitoisintofrekvenssit ovat toisintojen kokonaismäärän nähden matalat $\left(\mathrm{V}^{\mathrm{av} / \mathrm{t}}=\right.$ 0,6). Keskiarvoa laskee lisäksi se, että sävelmän puolivälissä on runsaasti tahtitoisintoja, joiden frekvenssi on poikkeuksellisen matala (tahdit 7-10).

Valtatoisintojen yhtenäisyyskerroin $\mathrm{Y}^{\mathrm{v}}$ : Maksimitoisintofrekvenssien hajonta on esimerkkisävelmien toiseksi suurin $\left(\mathrm{Y}^{\mathbf{v}}=3,87\right)$. Matalin maksimitoisintofrekvenssi on tahdissa 10 , jossa yleisintä toisintoa käyttää kahdestakymmenestä veisaajasta vain kuusi.

Tahtitoisintojen yhtenäisyyskerroin $\mathrm{Y}^{\mathrm{tt}}$ : Tahdeissa $1,3,13$ ja 14 on tahtitoisintojen frekvenssien hajonta suuri, kun taas tahdeissa 7-11 hajonta on pieni. Erityisesti tahdeissa 7-10 olevat poikkeavuustahdit ovat lähes yhtä paljon käytettyjä $\left(\mathrm{Y}^{\mathfrak{t t}}=4,24\right)$. Sävelmän tahtitoisintojen hajonta on esimerkkisävelmien suurin. 


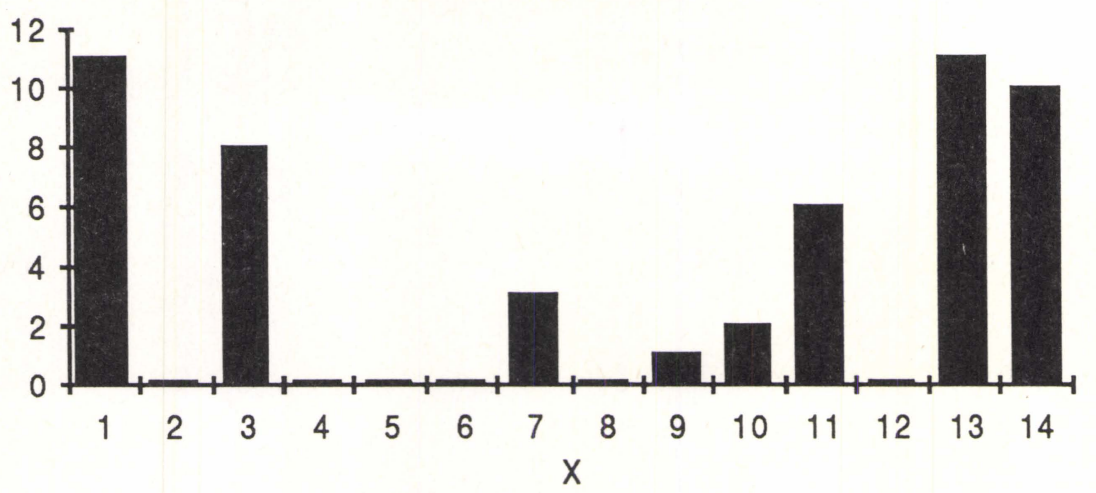

Sävelmän poikkeavuustahdit voidaan tahtitoisintojen frekvenssin suhteen jakaa kahteen ryhmää: tahdeissa 1, 3, 13 ja 14 tavataan yksi toisinto jota käyttävät lähes kaikki veisaajat; tahdeissa 7-11 käyttää tiettyä tahtitoisintoa noin puolet veisaajista. Suurimmassa osassa poikkeavuustahteja, joissa tahtitoisintojen frekvenssin hajonta on suuri, tavataan poikkeava tahtitoisinto samalta veisaajalta.

Poikkeavuustahtien sijainti Psi: Poikkeavuustahdit sijoittuvat selvästi sävelmän keskialueelle ja vielä siten, että sävelmän keskialueella on useita lähes yhtä paljon käytettyjä toisintoja.

Sävelmä n:o 34 on esimerkkinä toisintojoukosta, jossa poikkeavuudet sijoittuvat tiettyyn säkeeseen ja jossa on runsaasti lähes yhtä yleisesti käytössä olevia tahtitoisintoja. 
Kuva 42. Sävelmässä n:o 34 olevien poikkeavuustahtien määrä ja tahtitoisintojen frekvenssit.

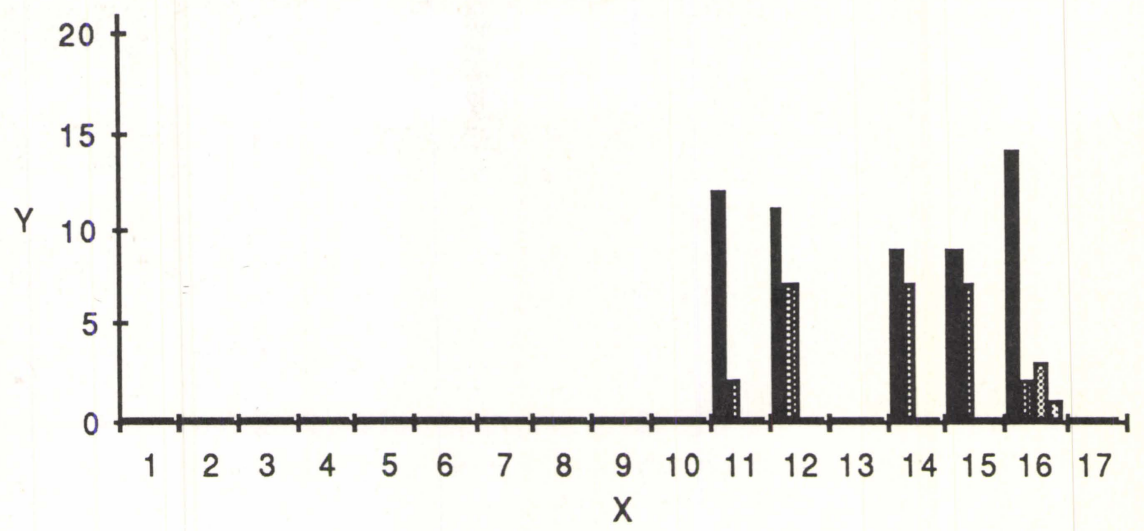

Sävelmää n:o 34 käytetään kuudessa eri virressä: HSHL 50, 81, 83, 110, 124 ja 135. Toisintoja on kaksikymmentäyksi ja veisaajia kymmenen.

Sävelmän yhtenäisyyskerroin $Y^{s}$ : Poikkeavuustahteja on kolmannes sävelmän tahdeista $\left(Y^{\mathbf{s}}=0,29\right)$.

Toisintojoukon yhtenäisyyskerroin $\mathrm{Y}^{\mathrm{t}}$ : Poikkeavuustahdeissa on yleensä vain muutama tahtitoisinto $\left(\mathrm{Y}^{\mathrm{t}}=0,03\right)$.

Poikkeavuustahtien suhteellinen frekvenssi $\mathrm{Pp}^{\mathrm{p} / \mathrm{t}}$ : Suhteessa toisintojen lukumäärään on poikkeavuustahteja varsin vähän $\left(\mathrm{P}^{\mathrm{P} / \mathrm{t}}=0,11\right)$.

$K u v a$ 43. Sävelmässä n:o 34 olevien poikkeavuustahtien määrä ja tahtitoisintojen frekvenssit.

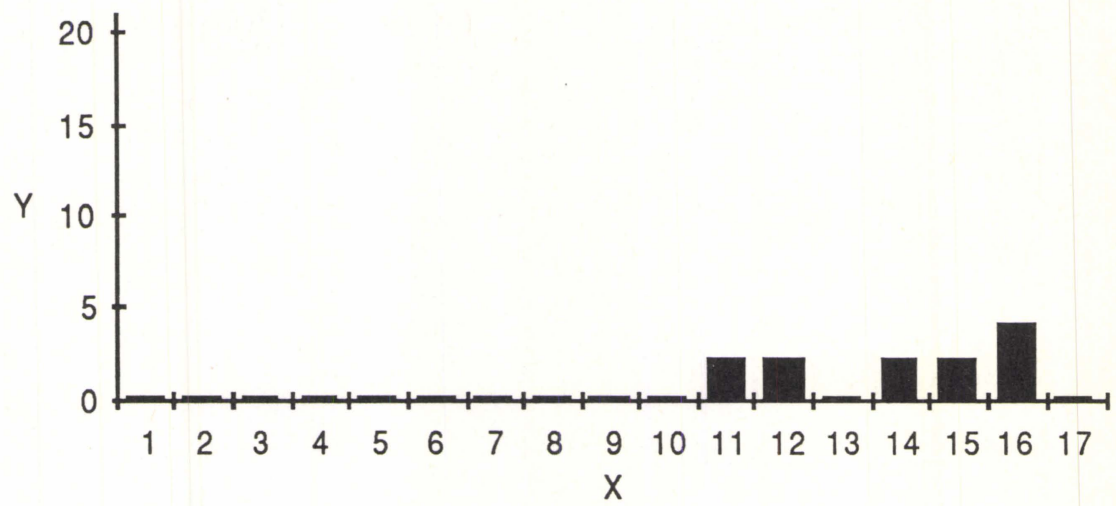

Poikkeavuustahtien yhtenäisyyskerroin $\mathrm{Y}^{\mathrm{P}}$ : Tahtitoisintoja on yhtä poikkeavuustahtia (tahti 16) lukuunottamatta vain kaksi ( $\left.Y^{\mathrm{P}}=0,89\right)$. 
Valtatoisintojen suhteellinen keskiarvo $\mathrm{V}^{\text {av/t: }}$ Maksimitoisintofrekvenssin keskiarvo on esimerkkisävelmien toiseksi alhaisin $\left(V^{a v / t}=0,52\right)$. Yleisintä tahtitoisintoa käyttää keskimäärin vain puolet veisaajista.

Valtatoisintojen yhtenäisyyskerroin $\mathrm{Y}^{\mathrm{v}}$ : Maksimitoisintofrekvenssin hajonta edustaa esimerkkisävelmien keskitasoa $\left(\mathrm{Y}^{\mathrm{v}}=2,12\right)$.

Tahtitoisintojen yhtenäisyyskerroin $\mathrm{Y}^{\mathrm{tt}}$ : Tahtitoisintojen frekvenssien hajonta on suuri $\left(Y^{\mathfrak{t}}=2,65\right)$. Tämä johtuu tahdeista 11 ja 16 , joissa on muista poikkeavuustahdeista poiketen käytössä yksi muista erottuva valtatoisinto.

Kuva 44. Sävelmän n:o 34 tahtitoisintojen frekvenssien hajonta.

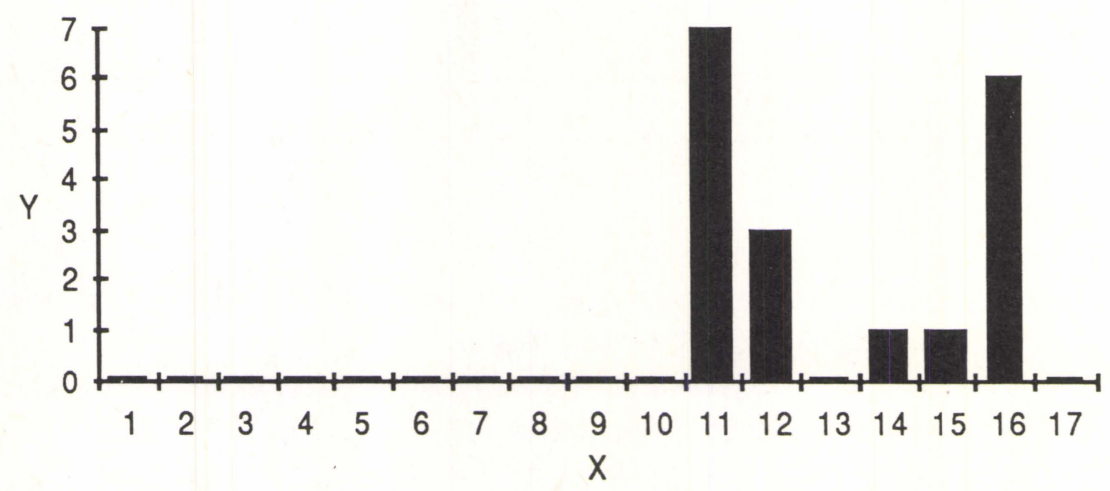

tahti 11

Poikkeavuustahtien sijainti Psi: Poikkeavuudet sijoittuvat selvästi sävelmän kahteen viimeiseen säkeeseen. Lisäksi kiinnittyy huomio siihen, että toiseksi viimeisessä tahdissa on poikkeuksellisen runsaasti tahtitoisintoja.

Sävelmä n:o 155 on esimerkkinä toisintojoukosta, jossa poikkeavuustahdit sijoittuvat tiettyyn sävelmän kohtaan ja jossa tietyssä tahdissa on poikkeuksellisen runsaasti tahtitoisintoja. 
Kuva 45. Sävelmässä n:o 155 olevien poikkeavuustahtien määrä ja tahtitoisintojen frekvenssit.

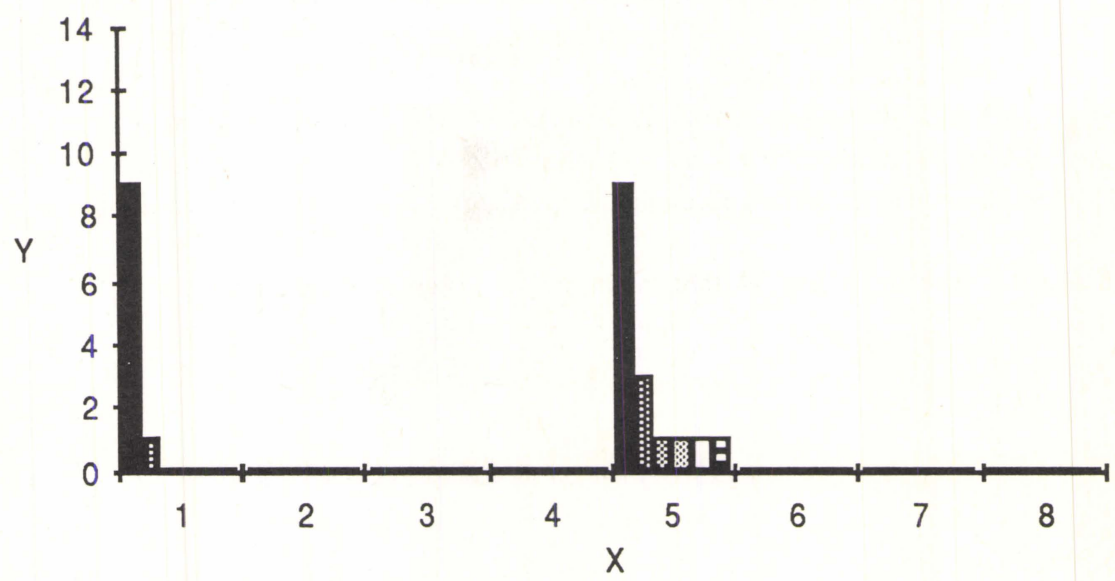

Sävelmää käytetään HSHL:ssa 144 ja 145. Toisintoja on neljätoista ja veisaajia yhdeksän.

Sävelmän yhtenäisyyskerroin $\mathrm{Y}^{\mathrm{s}}$ : Poikkeavuustahteja on vain kaksi sävelmän kahdeksasta tahdista $(Y s=0,25)$. Sävelmän yhtenäisyyskerroin on esimerkkisävelmien toiseksi matalin.

Toisintojoukon yhtenäisyyskerroin $\mathrm{Y}^{\mathrm{t}}$ : Sävelmän pituuteen ja toisintojen määrään nähden on poikkeavuustahteja hyvin vähän $\left(\mathrm{Y}^{t}=0,07\right)$. Toisintojoukon yhtenäisyyskertoimen arvoa nostaa tahdin viisi tahtitoisintojen suuri määrä.

Poikkeavuustahtien suhteellinen frekvenssi $\mathrm{Pp}^{\mathrm{p}}$ : Koska tahdissa viisi on tahtitoisintoja runsaasti, saa muuttuja korkean arvon $\left(\mathrm{P}^{\mathrm{p} / \mathrm{t}}=0,29\right)$. Sävelmän poikkeavuustahtien suhteellinen frekvenssi on esimerkkisävelmien toiseksi korkein. 
Kuva 46. Sävelmän n:o 155 poikkeavuustahtien määrä suhteessa toisintojen kokonaismärään.

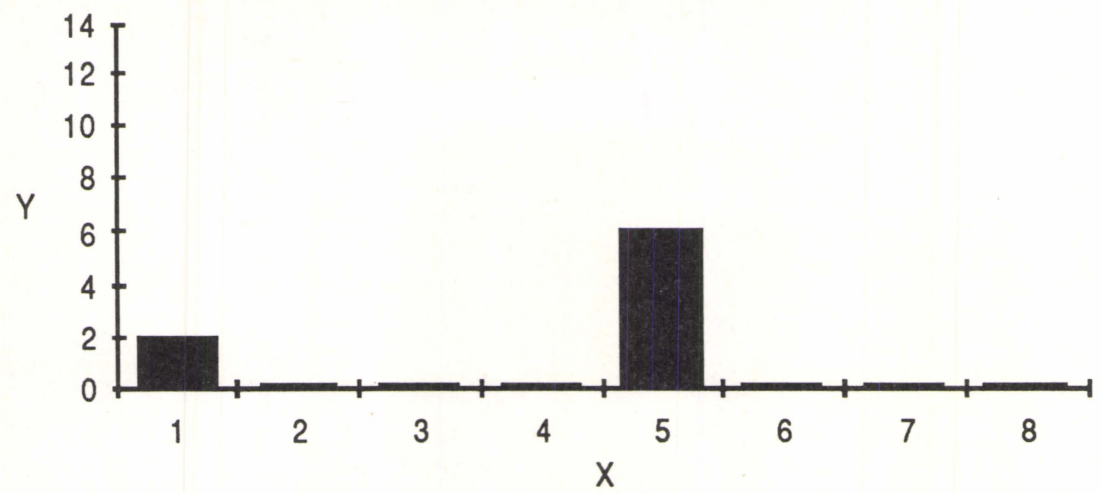

Poikkeavuustahtien yhtenäisyyskerroin YP: Tahtitoisintojen lukumäärän hajonta on esimerkkisävelmien suurin. Tämä johtuu jälleen tahdista viisi, jossa on peräti kuusi tahtitoisintoa ( $\left.\mathrm{YP}^{\mathrm{P}}=2,83\right)$

Valtatoisintojen suhteellinen keskiarvo $V^{a v / t}$ : Sävelmän kumpaakaan valtatoisintoa ei tavata kaikista toisinnoista $\left(\mathrm{V}^{\mathrm{av} / \mathrm{t}}=0,64\right)$.

Valtatoisintojen yhtenäisyyskerroin $\mathrm{Y}^{\mathrm{v}}$ : Maksimitoisintofrekvenssin hajonta on nolla, sillä molempia valtatoisintoja käyttää yhtä monta veisaajaa ( $Y^{\mathbf{v}}$ $=0)$.

Tahtitoisintojen yhtenäisyyskerroin $\mathrm{Y}^{\mathrm{tt}}$ : Tahtitoisintojen frekvenssin hajonta ei ole suuri. Tiettyä tahtitoisintoa käyttää joko suuri osa veisaajista tai vain yksi veisaaja $\left(\mathrm{Y}^{\mathrm{tt}}=1,73\right)$.

Kuva 47. Sävelmän n:o 155 tahtitoisintojen frekvenssien hajonta.

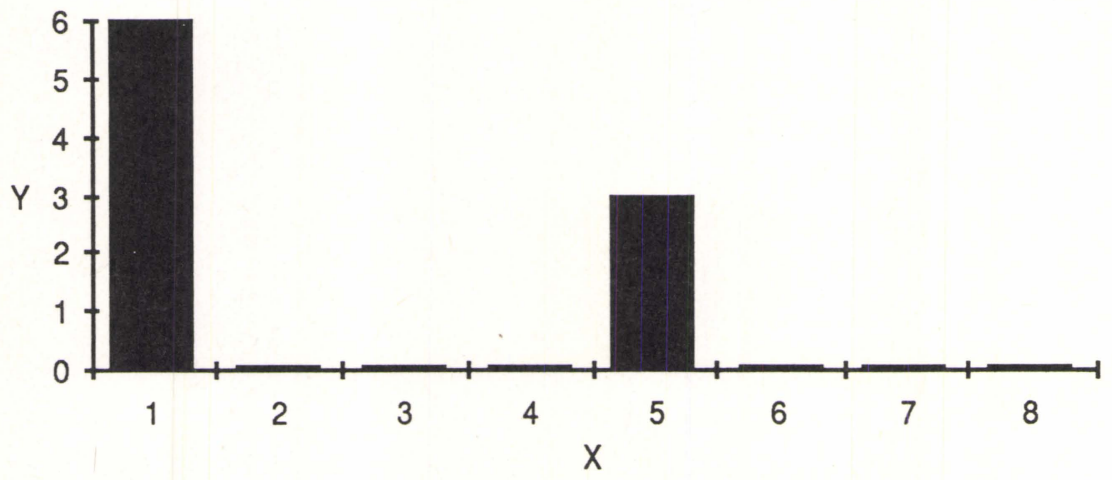

Poikkeavuustahtien sijainti Psi: Poikkeavuustahdit sijoittuvat sävelmän molempien säkeitten alkuun. 


\section{Tulosten tarkastelua}

Sävelmän ja toisintojoukon yhtenäisyyskertoimet

Seuraavassa kuvassa on vertailtu sävelmittäin sävelmän ja toisintojoukon yhtenäisyyskertoimien arvoja.

Kuva 48. Esimerkkisävelmien sävelmän (Ys) ja toisintojoukon (Yt) yhtenäisyyskertoimien arvot.

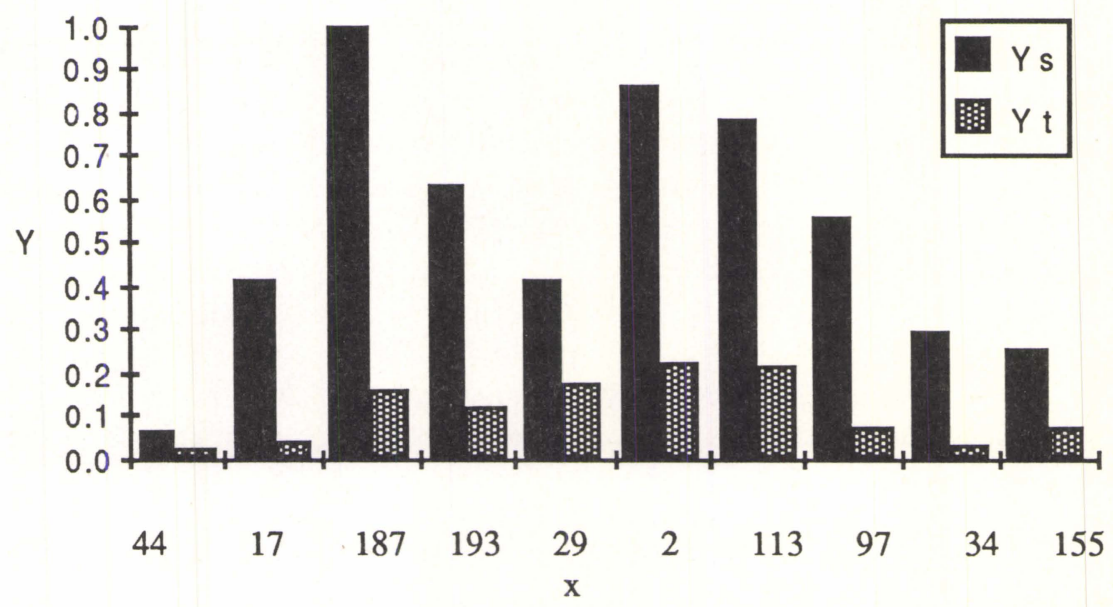

Sävelmän yhtenäisyyskertoimen arvoon ei vaikuta poikkeavuustahdeissa olevien tahtitoisintojen määrään, vaan jo yksikin poikkeama aiheuttaa sen, että tahti luetaan poikkeavuustahdiksi. Näin sävelmä, jossa on esimerkiksi vain yksi muista poikkeava toisinto, saa korkean yhtenäisyyskertoimen arvon. Sävelmän yhtenäisyyskertoimesta ei pidä tehdä päätelmiä ottamatta samalla huomioon muita sävelmän ja toisintojoukon ominaisuuksia kuvaavia tunnuslukuja.

Tällaisesta tilanteesta on esimerkkinä sävelmä n:o 2, jonka yhtenäisyyskerroin on lähes yhtä korkea kuin sävelmässä n:o 187. Tämän aiheuttaa se, että yksi veisaajista käyttää kahden säkeistön aikana useita toisintoja. Tässä tapauksessa siis yhden veisaajan poikkeavat toisinnot nostavat suhteettomasti tunnusluvun arvoa. Se että myös toisintojoukon yhtenäisyyskerroin on sävelmässä n:o 2 jopa korkeampi kuin sävelmässä n:o 187 johtuu siitä, että jälkimmäisessä on toisintojen kokonaismäärän ja sävelmän pituuden tulo suurempi kuin edellisessä.

Sävelmän yhtenäisyyskerrointa käytettäessä on huomattava, että poikkeavuus voidaan jakaa kahteen päätyyppiin: virheestä johtuvaksi tai tarkoitukselliseksi. Mikäli poikkeavassa toisinnossa on kyse todennäköisesti virheestä, antaa sävelmän yhtenäisyyskertoimen arvo kuvan veisuun "virheettömyydestä", mutta mikäli toisinnossa on kyse harvinaisesta, mutta perinnealueen toisintovarastoon kuuluvasta toisinnosta, antaa sävelmän yhtenäisyyskertoimen arvo kuvan veisuun yhtenäisyydestä. 
Sävelmän yhtenäisyyskertoimen puutteet huomataan myös vertailtaessa tunnusluvun arvoja sävelmissä n:o 17 ja 29. Molempien sävelmien yhtenäisyyskerroin on 0,41 , mutta kun tarkastellaan sävelmiä lähemmin huomataan, että sävelmän n:o 17 poikkeavuustahdeissa on yleensä vain muutama toisinto, kun taas sävelmässä n:o 29 on tahtitoisintoja runsaasti.

Sävelmän yhtenäisyyskerrointa ei voi pitää edellä mainituista rajoituksista huolimatta käyttökelvottomana, sillä vain tämä tunnusluku ottaa huomioon poikkeavuuksien suhteen sävelmän pituuteen.

Vertailtaessa sävelmien n:o 17 ja 29 toisintojoukon yhtenäisyyskertoimia huomataan, että sävelmä n:o 17 saa selvästi matalamman arvon kuin n:o 29 . Näin ollen vain toisintojoukon yhtenäisyyskertoimessa näkyy sävelmän n:o 29 tahtitoisintojen runsaus.

Toisintojoukon yhtenäisyyskertoimen merkitys huomataan myös vertailtaessa sävelmiä n:o 44 ja 155 . Molemmissa on suhteellisen vähän poikkeavuustahteja, mutta sävelmässä 155 on tahtitoisintoja selvästi enemmän. Vertailua tosin vaikeuttaa se, että molempiin kertoimiin vaikuttaa myös sävelmän pituus.

Toisintojoukon yhtenäisyykertoimen erityispiirre näkyy vertailtaessa sävelmiä n:o 17 ja 193. Molemmissa on varsin runsaasti poikkeavuustahteja eikä tahtitoisintojenkaan määrässä ole suurta eroa. Tästä huolimatta toisintojoukon yhtenäisyyskertoimien arvot poikkeavat toisistaan huomattavasti. Syynä on se, että kertoimen arvoon vaikuttaa sävelmän pituuden lisäksi myös toisintojen määrä. Sävelmässä n:o 17 on toisintoja huomattavasti enemmän kuin sävelmässä n:o 193.

\section{Poikkeavuustahtien suhteellinen frekvenssi ja yhtenäisyyskerroin}

Poikkeavuustahtien suhteellisen frekvenssin tavoitteena on antaa kuva siitä, kuinka paljon poikkeavuustahdeissa on keskimäärin tahtitoisintoja suhteessa toisintojen kokonaismäärään.

Kuva 49. Esimerkkisävelmien poikkeavuustahtien suhteelliset frekvenssit.

\section{$\mathrm{P} p / \mathrm{t}$}

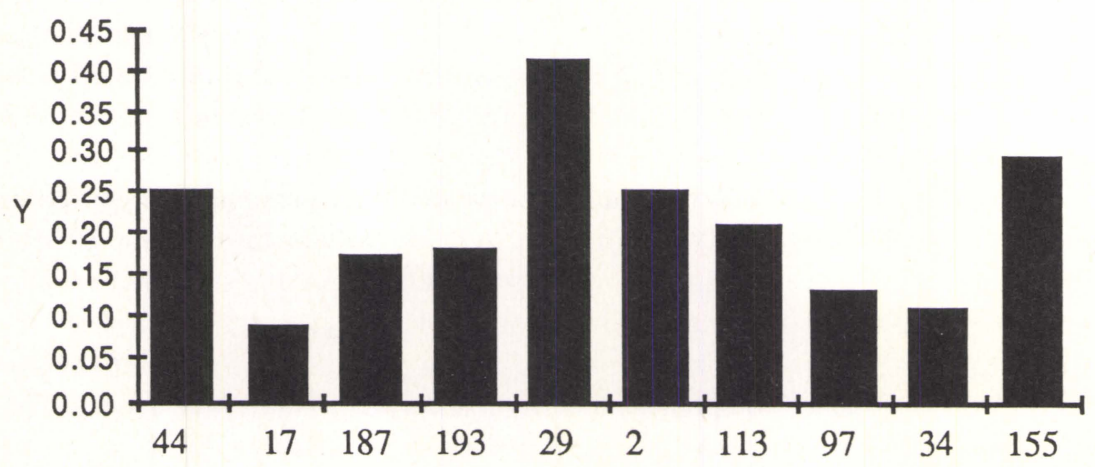


On muistettava, ettei tämä tunnusluku ole lainkaan riippuvainen poikkeavuustahtien määrästä. Tämä näkyy selvästi vertailtaessa kahta korkeimman arvon saanutta sävelmää: sävelmässä n:o 29 on runsaasti poikkeavuustahteja, kun taas sävelmässä n:o 155 näitä on vain kaksi. Sävelmän n:o 155 korkea arvo johtuu siitä, että jälkimmäisessä poikkeavuustahdissa on runsaasti tahtitoisintoja.

Poikkeavuustahtien suhteellista frekvenssiä voi pitää erityisen hyödyllisenä tunnuslukuna toisaalta siksi, että sen avulla löydetään sävelmät, joissa on erityisen runsaasti tahtitoisintoja suhteessa toisintojen määrään ja toisaalta siksi, ettei tunnuslukua pääse häiritsemään sävelmän pituus tai poikkeavuustahtien määrä. Tunnusluvun tulkintaa vaikeuttaa se, että sen arvoa nostaa yksikin tahti, jossa on runsaasti tahtitoisintoja (sävelmä n:o 155).

Juuri tämän puutteen korjaamiseksi on edellä kehitetty poikkeavuustahtien yhtenäisyyskerroin, joka ottaa huomioon sen, kuinka paljon poikkeavuustahtien tahtitoisintojen määrissä on vaihtelua.

Kuva 50. Esimerkkisävelmien poikkeavuustahtien yhtenäisyyskertoimet.

Yp

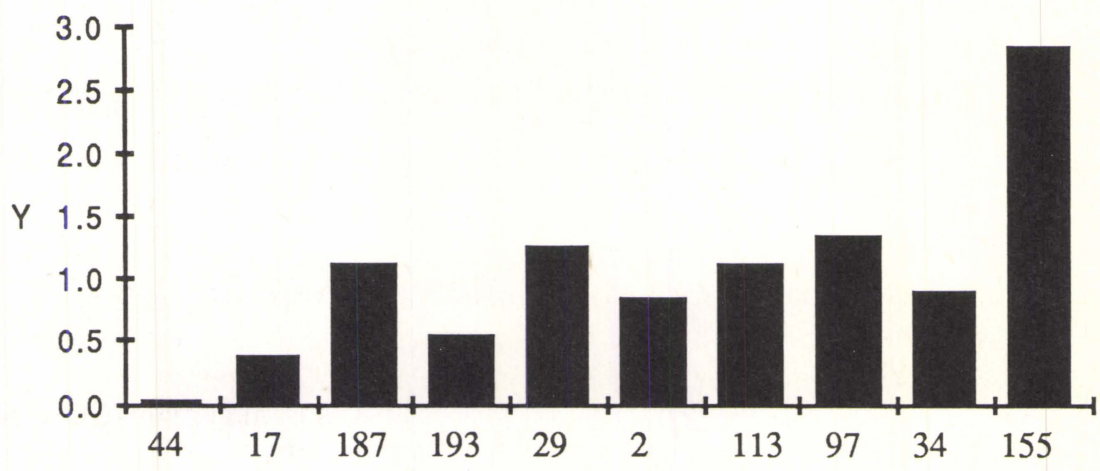

Kuvasta 50 huomataan, että sävelmässä n:o 155 on poikkeavuustahtien hajonta suurin. Tämän tunnusluvun avulla löydetäänkin toisintojoukot, joiden tietyissä poikkeavuustahdeissa on erityisen runsaasti (tai erityisen vähän) tahtitoisintoja.

Yhtenäisyyskertoimen puutteena näyttää olevan se, että sävelmissä joissa on runsaasti poikkeavuustahteja, joiden tahtitoisintojen määrissä ei ole suurta hajontaa, mutta sävelmissä on yksi tai muutama poikkeavuustahti, jonka tahtitoisintojen määrä poikkeaa muista, tulee yhtenäisyyskertoimen arvo matalaksi. Tällaisesta tapauksesta on esimerkkinä sävelmä n:o 113. Siinä on kahdeksannessa tahdissa selvästi keskimääräistä enemmän tahtitoisintoja, mutta koska useimmissa poikkeavuus-tahdeissa ei hajontaa juurikaan ole, ei poikkeavuustahtien yhtenäisyyskerroin eroa muista esimerkkisävelmistä (vrt. sävelmään n:o 187). 
Seuraavassa kuvassa on sävelmittäin esitetty valtatoisintojen suhteelliset keskiarvot ja yhtenäisyyskertoimet.

Kuva 51. Esimerkkisävelmien valtatoisintojen suhteelliset keskiarvot $\left(\mathrm{V}^{\mathrm{av} / \mathrm{t}}\right) \mathrm{ja}$ yhtenäisyyskertoimet $\left(\mathrm{Y}^{\mathbf{v}}\right)$.

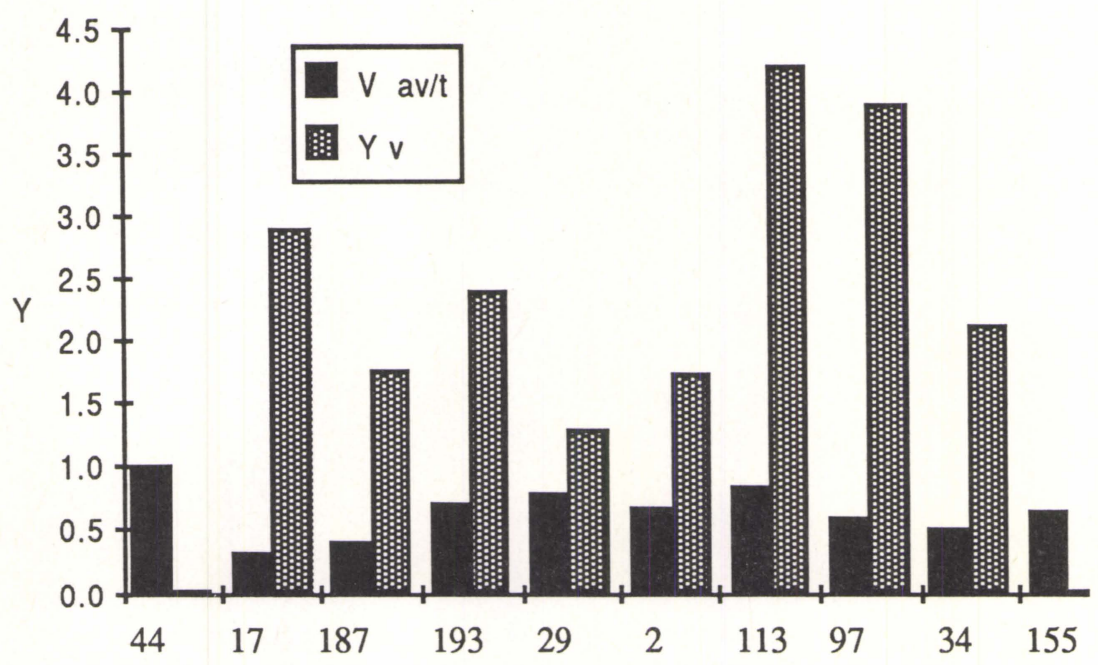

Kuvasta huomataan, että useimmissa toisintojoukoissa on valtatoisintojen keskiarvo lähellä yhtä. Tämä tarkoittaa sitä, että valtatoisintojen frekvenssi on lähes yhtä suuri kuin toisintojen kokonaismäärä. Sävelmät n:o 17 ja n:o 187 poikkeavat tämän tunnusluvun suhteen selviten muista sävelmistä.

Valtatoisintojen suhteellinen keskiarvo on yhteydessä tahtitoisintojen lukumäärään: mikäli poikkeavuustahdeissa on runsaasti tahtitoisintoja, joiden frekvenssi on korkea, laskee valtatoisintojen frekvenssi (ks. sävelmä n:o 17, tahti 15). On tosin mahdollista, että suuri osa veisaajista käyttää valtatoisintoa, mutta tämän lisäksi he tuntevat jonkin vähemmän käytetyn toisinnon. Tällaisessa tapauksessa voi valtatoisintojen suhteellinen keskiarvo olla korkea huolimatta tahtitoisintojen runsaudesta (ks. sävelmä n:o 155).

Edellä kuvatut toisintojoukot löytyvät etsimällä toisintojoukkoja, joissa on samanaikaisesti korkea valtatoisintojen suhteellinen keskiarvo ja matala poikkeavuustahtien yhtenäisyyskertoimen arvo.

Valtatoisintojen yhtenäisyyskertoimen avulla oli tarkoitus selvittää kuinka suuria eroavuuksia on valtatoisintojen frekvensseissä. Erityisen suuri hajonta on sävelmissä n:o 113 ja 97 . Valtatoisintojen yhtenäsyyskerroin näyttää olevan yhteydessä poikkeavuustahdeissa olevien tahtitoisintojen määrään ja frekvenssiin: mitä enemmän tahtitoisintoja ja mitä korkeampi niitten frekvenssi on, sitä vähemmän jää "tilaa" valtatoisinnolle. Esimerkiksi sävelmän n:o 113 korkea $Y^{\mathbf{v}}$ arvo johtuu siitä, että toiseksi viimeisessä tahdissa on useita lähes yhtä yleisessä käytössä olevia toisintoja (ks. myös n:o 17). 
Voidaankin pohtia sitä, onko tällä tunnusluvulla lainkaan itsenäistä arvoa, vai năhdäănkő samat asiat jo muista tunnusluvuista. Usein kenties nähdään, mutta mikäli valtatoisintojen frekvensseissä ja poikkeavuustahtien yhtenäisyyskertoimissa ei ole eroa, saadaan vain valtatoisintojen yhtenäisyyskertoimella etsityksi sävelmät, joissa valtatoisintojen frekvenssit vaihtelevat. Tunnusluvut eivät siis ole toisistaan riippumattomia ja tietyissä tapauksissa useat tunnusluvut mittaavat samaa asiaa. Tästä huolimatta kullakin tunnusluvulla on erityistehtävä, joita muut tunnusluvut eivät voi korvata.

\section{Tahtitoisintojen yhtenäisyyskerroin}

Kuvassa 52 tarkastellaan esimerkkisävelmien yhtenäisyyskertoimien arvoja.

Kuva 52. Esimerkkisävelmien tahtitoisintojen yhtenäisyyskertoimet.

$$
Y \mathrm{tt}
$$

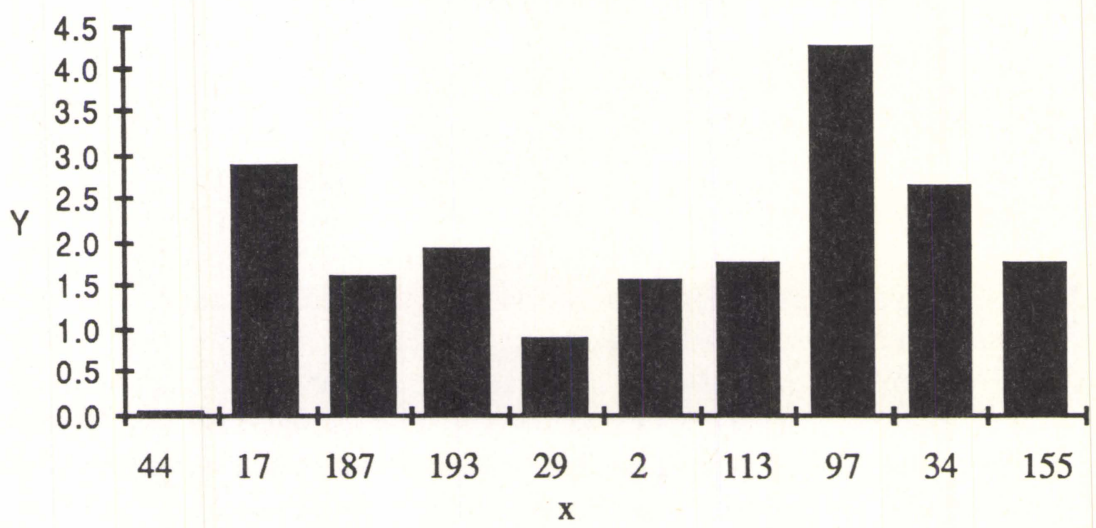

Kuvassa 52 huomataan, että suurin tahtitoisintojen frekvenssien hajonta on sävelmässä n:o 97. Tunnusluvun korkea arvo ei merkitse sitä, että kussakin poikkeavuustahdissa olisi tahtitoisintojen frekvensseissä paljon vaihtelua, vaan että tietyn tahdin tai tiettyjen tahtien tahtitoisintojen frekvenssit suhtautuvat toisiinsa eri tavoin kuin tavallisesti. Tunnusluku saa korkean arvon sekä silloin, kun useimmissa poikkeavuustahdeissa ei tahtitoisintojen frekvensseissä ole eroa, mutta yhdessä poikkeavuustahdissa eroa on, että silloin kuin useimmissa poikkeavuustahdeissa on huomattavia tahtitoisintojen frekvenssien eroavuuksia, mutta yhdessä poikkeavuustahdissa ei eroavuutta ole. Esimerkiksi sävelmän n:o 17 korkea tunnusluvun arvo johtuu siitä, että tahdissa viisitoista on tahtitoisintojen frekvensseissä poikkeuksellisen vähän eroavuutta. Sävelmässä n:o 97 on tietyssä säkeessä (tahdit 7-10) runsaasti samafrekvenssisiä tahtitoisintoja, kun taas muissa tahdeissa on frekvenssien hajonta suuri. 
Tahtitoisintojen yhtenäisyyskertoimen antamat tunnusluvun arvot ovat hyvin lähellä valtatoisintojen yhtenäisyyskertoimen arvoja. Seuraavassa kuvassa on vertailtu sävelmittäin näitä kahta tunnuslukua.

Kuva 53. Esimerkkisävelmien tahtitoisintojen $\left(\mathrm{Y}^{\mathrm{tt}}\right)$ ja valtatoisintojen $\left(\mathrm{Y}^{\mathrm{v}}\right)$ yhtenäisyyskertoimien arvot.

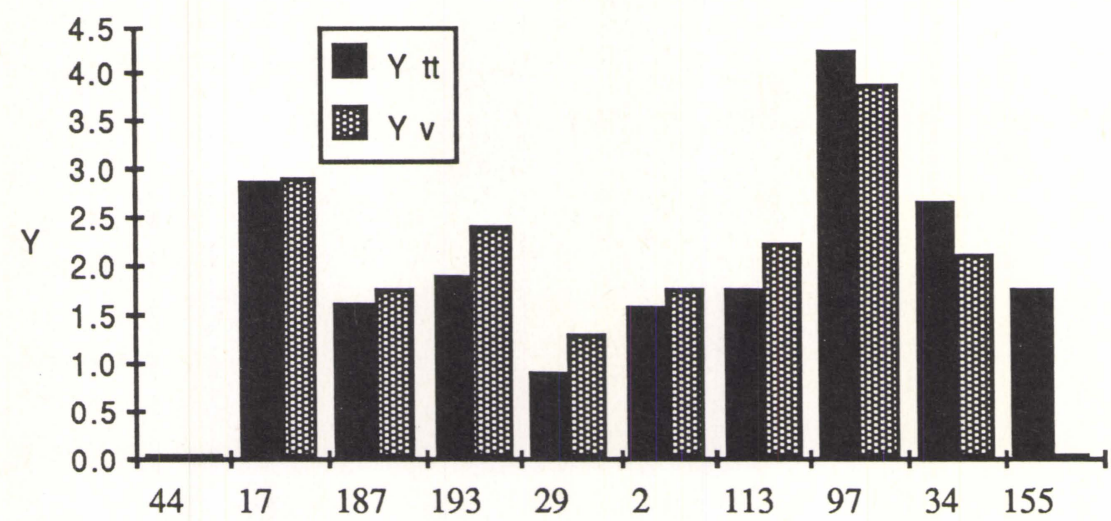

Myös tässä tapauksessa voidaan kysyä, onko tahtitoisintojen yhtenäisyyskertoimella lainkaan itsenäistä arvoa. Siinä tapauksessa, että poikkeavuustahtien valtatoisintojen frekvenssit eivät vaihtele, mutta tahtitoisintojen frekvenssit vaihtelevat, antavat nämä tunnusluvut toisistaan poikkeavat arvot. Näin on vain silloin, kun sävelmässä on poikkeavuustahti, jossa on valtatoisinnon lisäksi useita matalafrekvenssisiä tahtitoisintoja samalla kun muissa poikkeavuustahdeissa ei tahtitoisintojen frekvensseissä ole eroavuutta (ks. sävelmä n:o 155).

Ainoa sävelmä, jossa näiden kahden tunnusluvun arvot eroavat huomattavasti on sävelmä n:o 155 . Se, että maksimitoisintofrekvenssit ovat samat huolimatta siitä, että jälkimmäisessä poikkeavuustahdissa on poikkeavuusfrekvenssi korkea, johtuu siitä, että samat veisaajat käyttävät eri toisintoa säkeen kertauksessa.

\section{Poikkeavuustahtien sijainti}

Poikkeavuustahtien sijainnille ei tässä yhteydessä ole laskettu omaa tunnuslukua, vaan sijaintia on tarkasteltu kunkin sävelmän kohdalla esitetyistä kuvaajista. Yhtenä tämän tutkimuksen yhteydessä esille tulleena kysymyksenä on juuri se, mikä tai mitkä syyt aiheuttavat poikkeavuuksien keskittymisen tiettyyn sävelmän kohtaan.

Kun lisäksi tarkasteltiin poikkeavuustahtien tahtitoisintojen määrän jakautumista 199 sävelmässä (tapauksia 1799), huomattiin poikkeavuuksien jakautuman noudattavan useimmissa säkeissä kuvassa 54 näkyvää logiikkaa. 


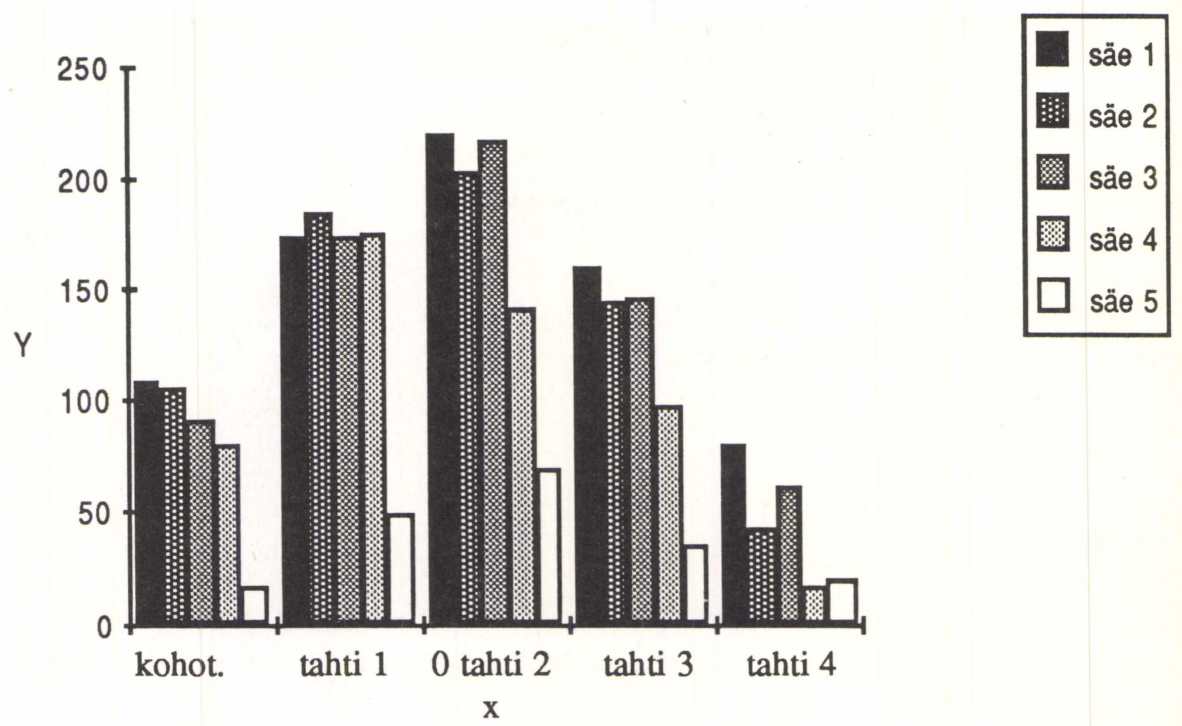

Kuvasta huomataan, ettă poikkeavuudet keskittyvät toiseen tahtiin ja että vähiten niitä tavataan kohotahdissa ja säkeen viimeisessä tahdissa. Vain neljănsissä säkeissä poikkeavuudet keskittyvät säkeen ensimmäiseen tahtiin. Silmiinpistävää on myös poikkeavuuksien määrän pieni vaihtelu varsinkin kolmessa ensimmäisessä säkeessä.

Vaikka tässä yhteydessä ei ryhdytä tarkemmin pohtimaan poikkeavuuksien sijaintia selittäviă tekijöită, esitetăăn kuitenkin muutama oletus. Voidaan olettaa, että sävelmä jakautuu kahteen pääalueeseen: toista nimitän yleiseksi osaksi ja toista tunnusosaksi. Yleisellä osalla tarkoitetaan sävelmästä toiseen toistuvia, toisiaan muistuttavia paradigmoja (esim. kadenssit). Tunnusosalla tarkoitetaan sävelmän osaa, joka erottaa sen muista sävelmistä. Yleisessä osassa käytetyt paradigmat ovat suurimmalle osalle veisaajista tuttuja; ne kuuluvat vakioparadigmojen joukkoon. Sävelmän tunnusosassa on suurempi hajonta. Tunnusosassa käytettyjä paradigmoja on enemmän ja ne poikkeavat tosistaan enemmän, joten niitten muistaminenkaan ei ole yhtä helppoa kuin yleisen osan vakioparadigmojen muistaminen.

Sävelmän rakennetta voi kuvata seuraavan kaavion avulla.

\begin{tabular}{cccclc} 
toisinto 3 & a & b2 & e & h \\
toisinto & 2 & a & b1 & d & h \\
toisinto & 1 & a & b & $c$ & h \\
& \multicolumn{2}{c}{ yleinen osa tunnusosa } & & yleinen osa \\
& & karakt. & loppuosa
\end{tabular}

Kaaviossa on tietystä sävelmästä olemassa kolme toisintoa. Kaikilla on sama yleinen osa (osat a ja h), mutta tunnusosat vaihtelevat. Tunnusosan voidaan 
olettaa jakautuvan kahteen osaan: karakteristiseen osaan ja loppuosaan. Karakteristinen osa on sävelmän kannalta keskeinen, ja se on yleensä painollisella sävelmän osalla. Painollisuus puolestaan määräytyy sävelmän metrisestä rakenteesta. Jos săvelmässă on neljă tahtia, saisi ensimmäinen tahti pääpainon ja kolmas sivupainon. Toinen ja neljäs tahti saisivat vähiten painoa. Mitä painottomampi sävelmăn osa on sită mahdollisempi on poikkeavuus ilman, että se häiritsee sävelmän tunnistettavuutta.

Poikkeavuuksien sijaintia voitaisiin tarkastella generatiivisessa musiikinteoriassa käytetyllä puumallilla (Ks. Sundberg 1972). Mitä ylemmällä hierarkiassa liikutaan sitä vähemmän tavataan poikkeavuutta ja päin vastoin. Lisäksi poikkeavuuksien määrään vaikuttaisi sävelmän osa. Vaikka paradigma sijaitsisi sävelmän heikolla osalla, mutta jos se kuuluu yleiseen osaan, ei siinä juurikaan tavattaisi poikkeavuuksia.

\section{Käytetyt lyhenteet ja käsitteiden määrittelyä}

$\operatorname{sp}(\mathrm{A})=$ toisintojoukon $\mathrm{A}$ sävelmän pituus

$\operatorname{tf}(A)=$ toisintojoukon $A$ toisintojen lukumäärä

$\operatorname{vf}(\mathrm{A})=$ toisintojoukon $\mathrm{A}$ veisaajien lukumäärä

$\mathrm{tt}(\mathrm{A})=$ tahtitoisinto

toisintojoukon A sävelmän poikkeavuustahdin toisinto

$\operatorname{tntm}(\mathrm{A})=$ tahtitoisinto $\mathrm{n}, \mathrm{m}$

toisintojoukon $\mathrm{A}$ sävelmän poikkeavuustahdin $\mathrm{n}$ toisinto $\mathrm{m}$

esim. $\mathrm{t}^{3} \mathrm{p}^{5}=$ tahdin 3 toisinto 5

$\operatorname{tntmf}(\mathrm{A})=$ tahdin $\mathrm{n}$ tahtitoisinnon $\mathrm{m}$ frekvenssi (=toisintofrekvenssi)

toisintojoukon A poikkeavuustahdin $\mathrm{n}$ toisinnon $\mathrm{m}$ frekvenssi eli kuinka monta veisaajaa käyttää tahdissa $\mathrm{n}$ toisintoa $\mathrm{m}$.

$\operatorname{pt}(\mathrm{A})=$ poikkeavuustahti

toisintojoukon A sävelmän tahti, josta tavataan kaksi tai useampia toisistaan melodisesti poikkeavia muotoja

$\operatorname{ptn}(\mathrm{A})=$ poikkeavuustahti $n$

toisintojoukon A sävelmän poikkeavuustahti $n$

esim. $\mathrm{pt}^{2}(\mathrm{~A})=$ toisintojoukon $\mathrm{A}$ sävelmän tahti 2 , joka on samalla poikkeavuustahti

$\operatorname{ptnf}(\mathrm{A})=$ tahdin $\mathrm{n}$ poikkeavuusfrekvenssi

toisintojoukon A poikkeavuustahdin $\mathrm{n}$ tahtitoisintojen frekvenssi eli kuinka monta erilaista tahtitoisintoa tavataan poikkeavuustahdissa $n$ 
$\operatorname{Pt}(\mathrm{A})=$ poikkeavuustahtien lukumäärä toisintojoukon $\mathrm{A}$ sävelmässä toisintojoukon A sävelmässä olevien sellaisten tahtien määrä, jossa on kaksi tai useampia tahtitoisintoja

$\operatorname{Ptf}(\mathrm{A})=$ poikkeavuustahtien frekvenssien summa toisintojoukossa $\mathrm{A}$ toisintojoukon A poikkeavuustahtien frekvenssien summa eli kuinka monta erilaista tahtitoisintoa toisintojoukossa A kaiken kaikkiaan tavataan

\section{Esimerkkitapaus}

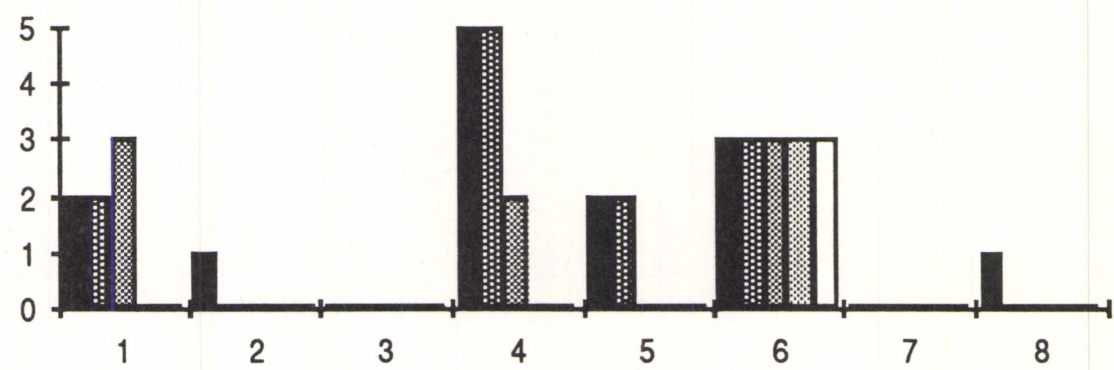

poikkeavuustahteja (pt) ovat tahdit $1,2,4,5,6$ ja 8

tahtitoisintojen $\mathrm{t} 4 \mathrm{t} 1$ ja $\mathrm{t} 4 \mathrm{t} 2$ toisintofrekvenssi on 5 tahtitoisintojen $\mathrm{t} 4 \mathrm{t} 3, \mathrm{t} 5 \mathrm{t} 1$ ja $\mathrm{t} 5 \mathrm{t} 2$ toisintofrekvenssi on 2

tahdin 2 poikkeavuusfrekvenssi eli tahtitoisintojen lukumäärä tahdissa $2(p t 2 f)=1$ tahdin 5 poikkeavuusfrekvenssi eli tahtitoisintojen lukumäärä tahdissa $5(\mathrm{pt} 5 \mathrm{f})=2$ tahdin 6.poikkeavuusfrekvenssi eli tahtitoisintojen lukumäärä tahdissa 6 (pt6f) $=5$ poikkeavuustahtien lukumäärä toisintojoukossa $\mathrm{A}$ eli $\operatorname{Pt}(\mathrm{A})=6$

tahtitoisintojen lukumäärä koko toisintojoukossa eli $\operatorname{Ptf}(\mathrm{A})=15$ $(3+1+0+3+2+5+0+1)$ 


\section{Liitteet}

Sävelmä n:o 2
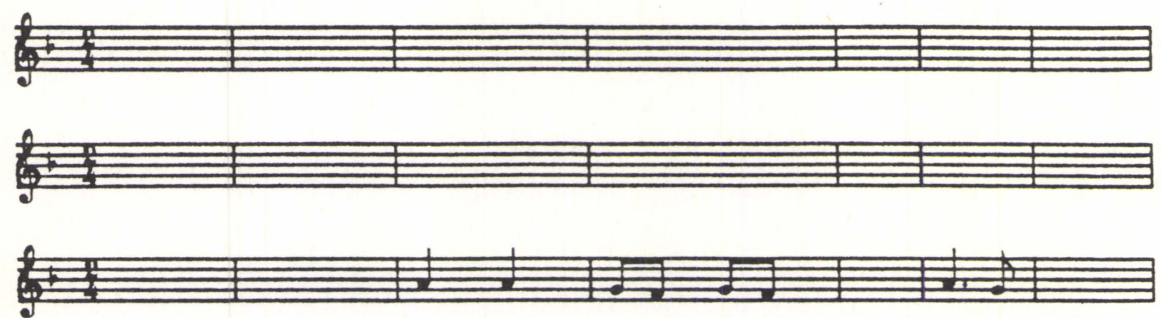

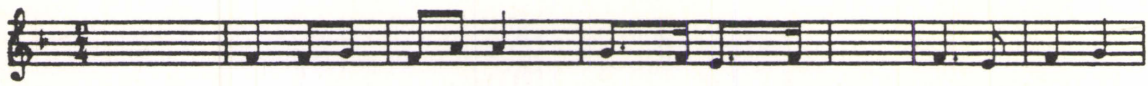
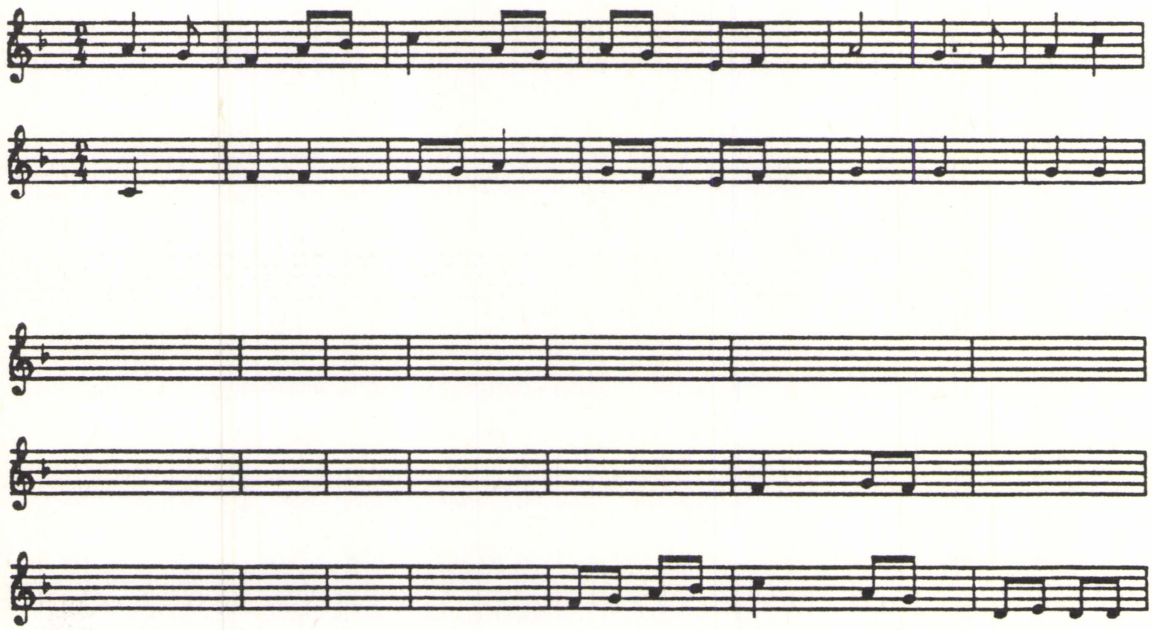

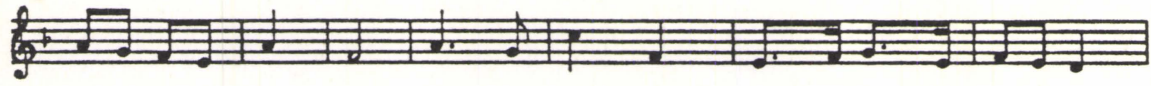
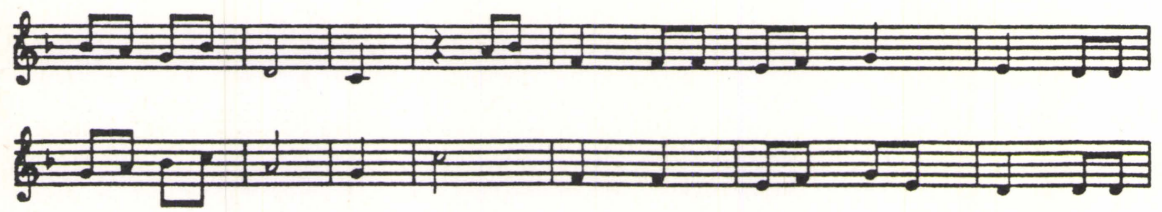

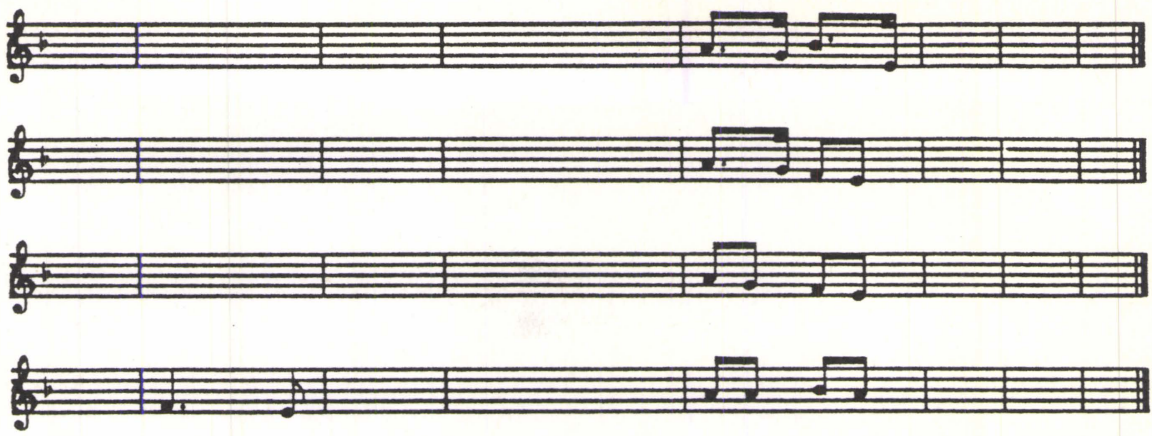

101010

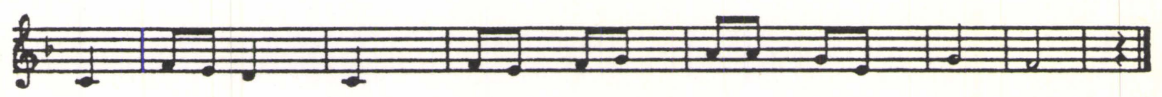

Sävelmä n:o 17

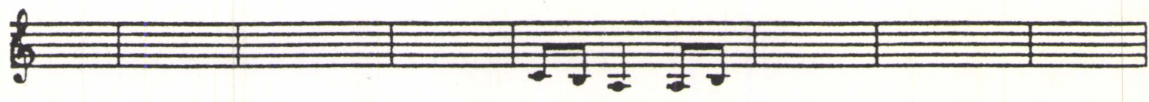

(1)

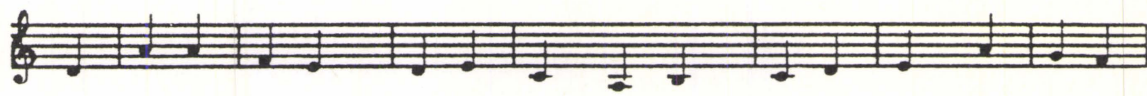

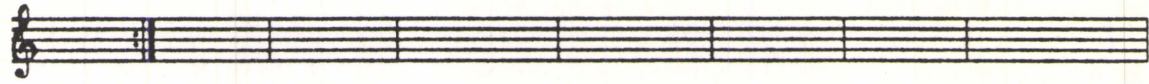

(1)

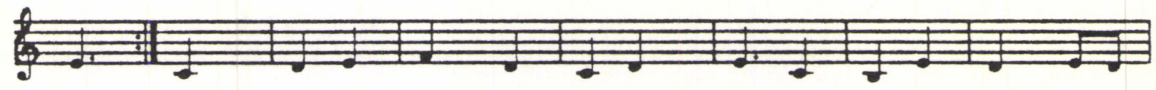
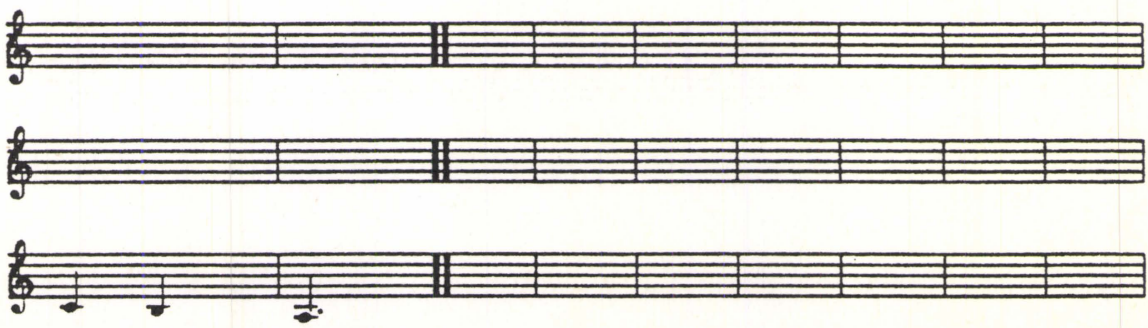
Sävelmä n:o $29 b$

t: 2

\&"1:
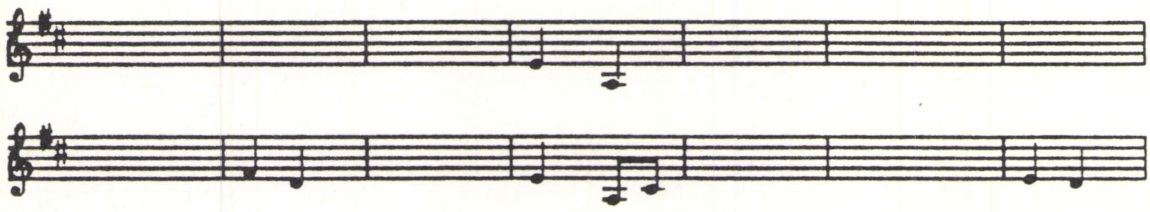

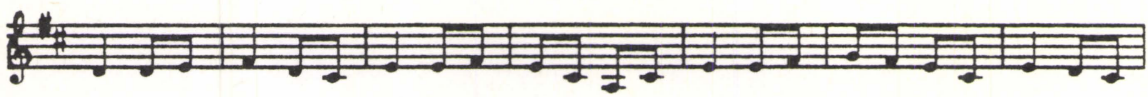
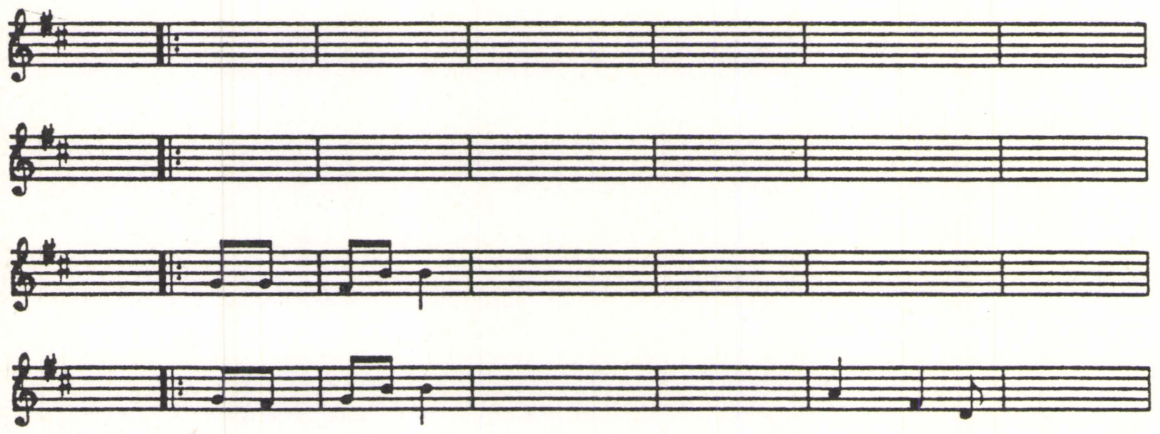

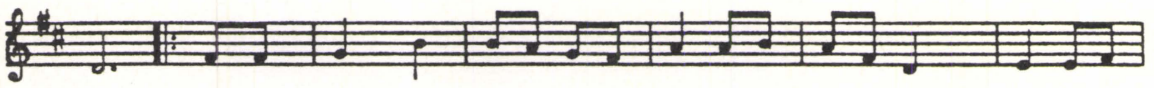
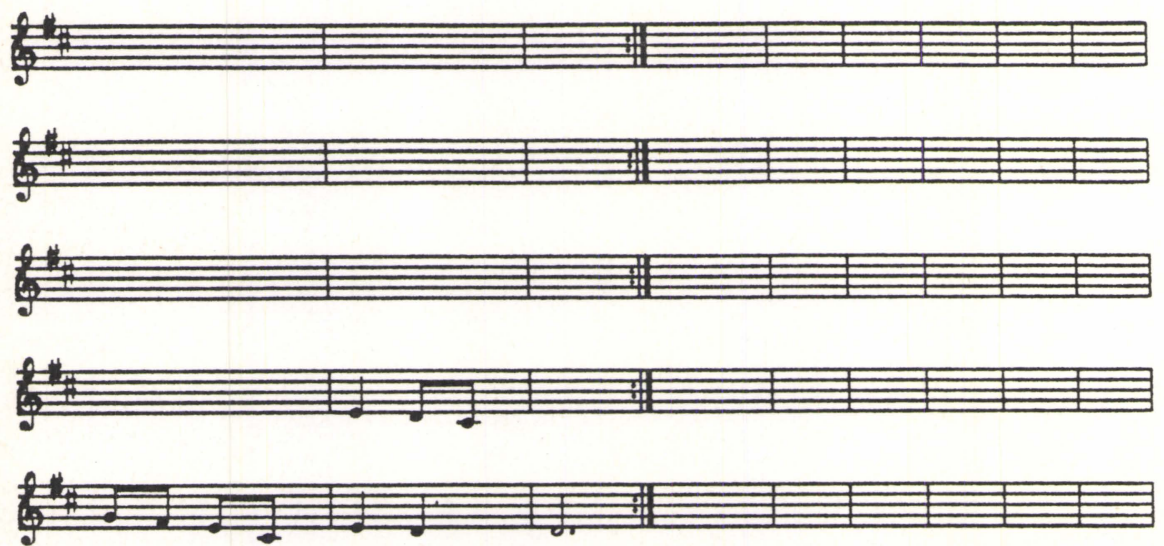
Sävelmä n:o 34
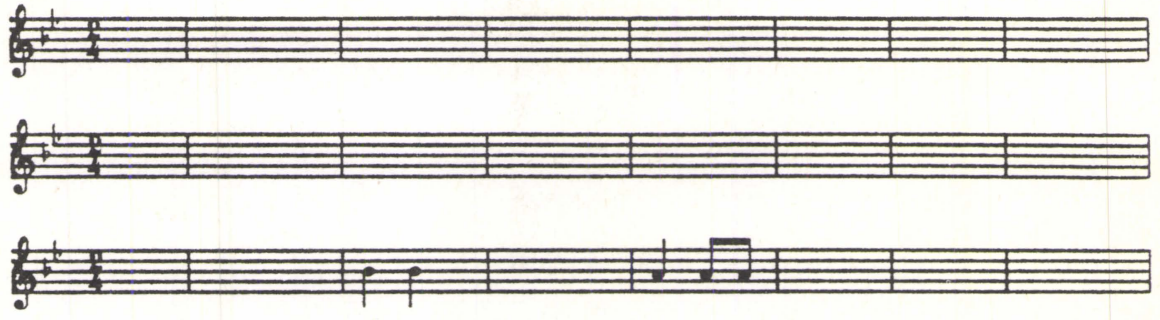

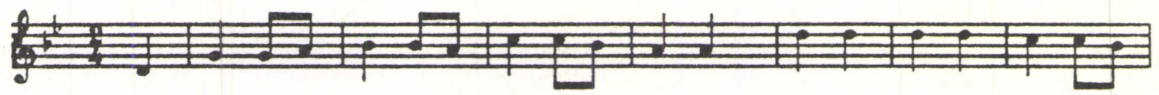
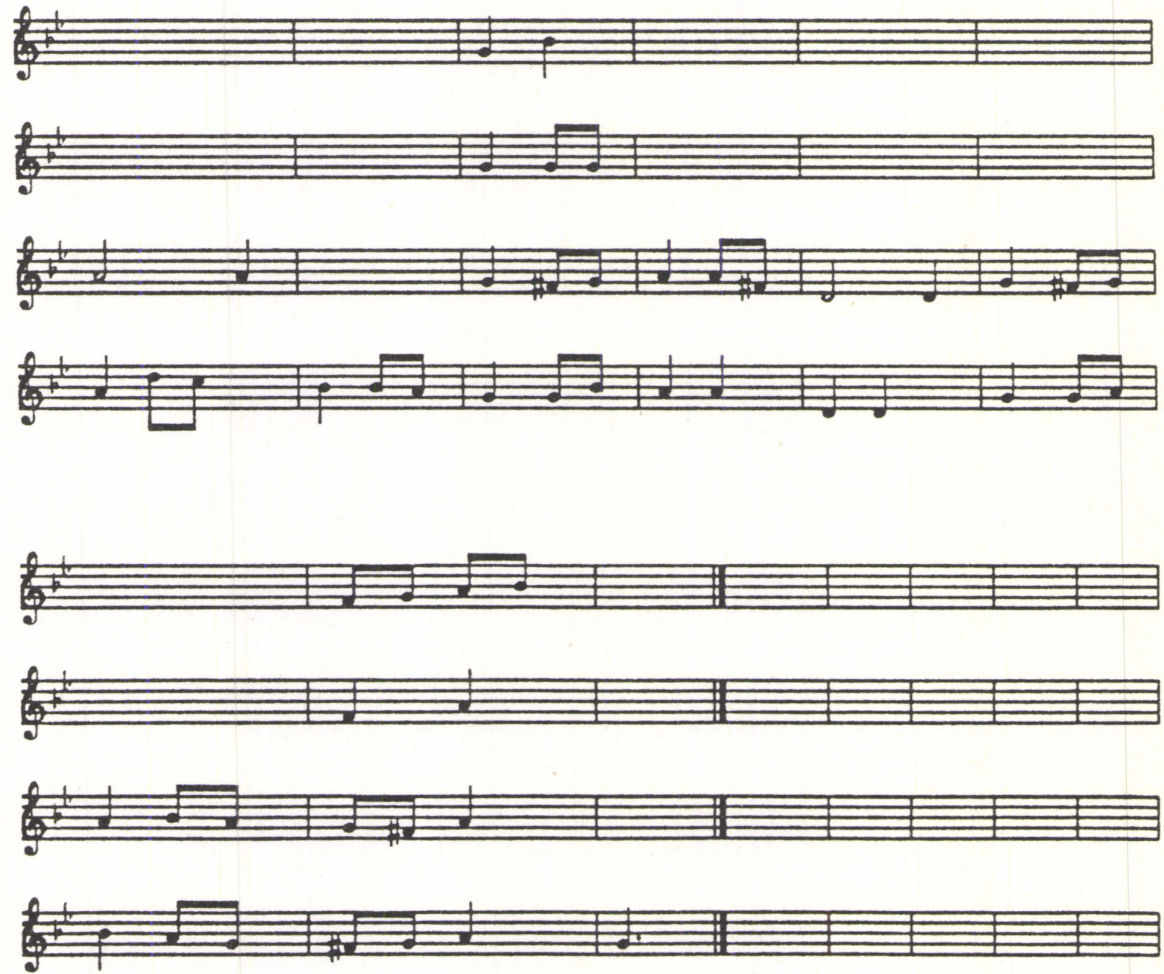
Sävelmä n:o 44
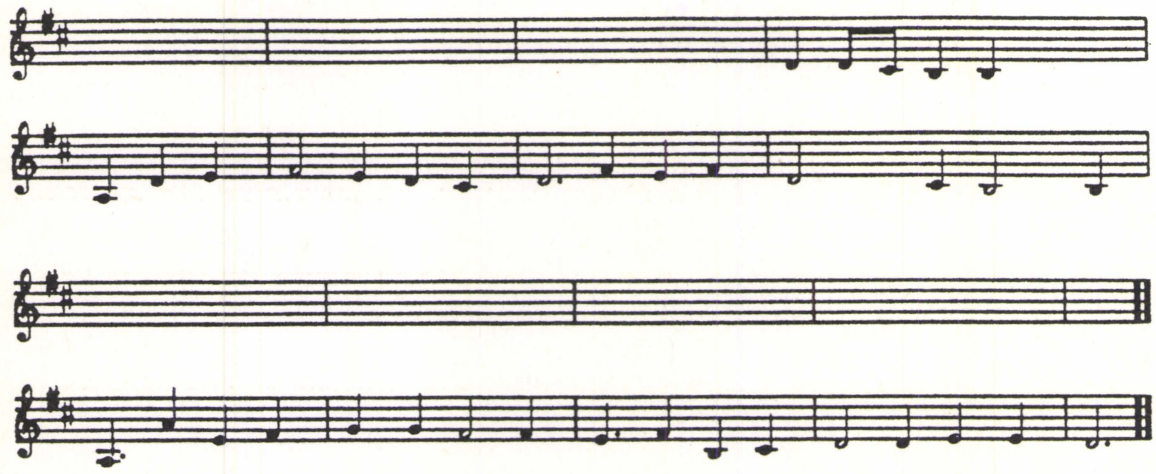

Sävelmä n:o 97
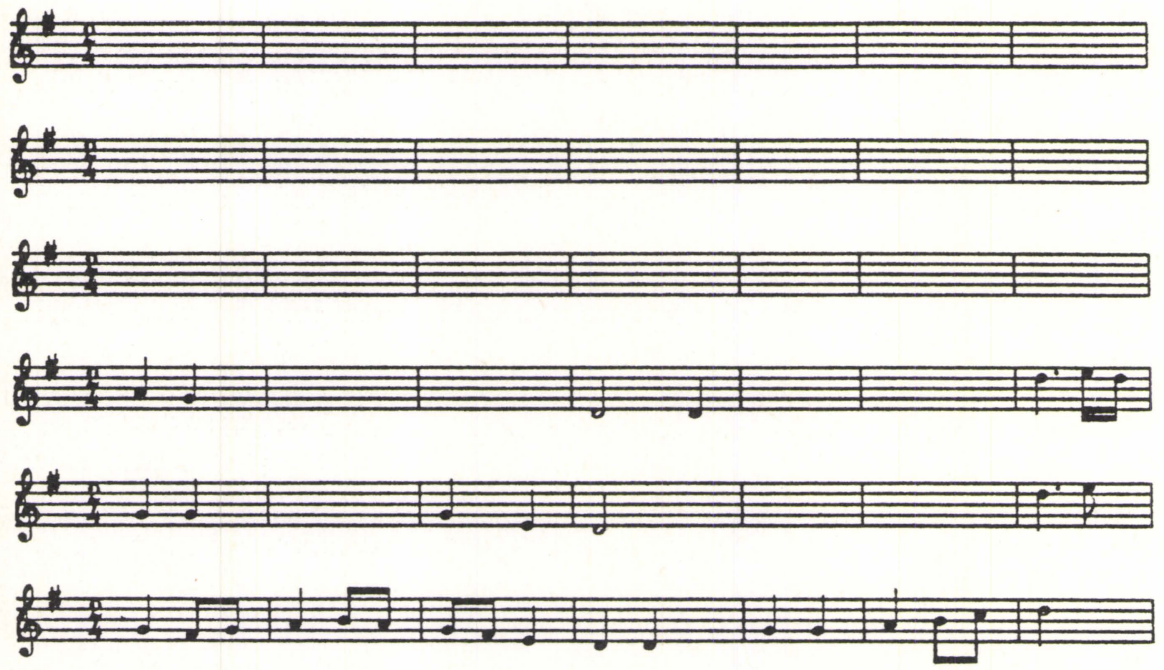

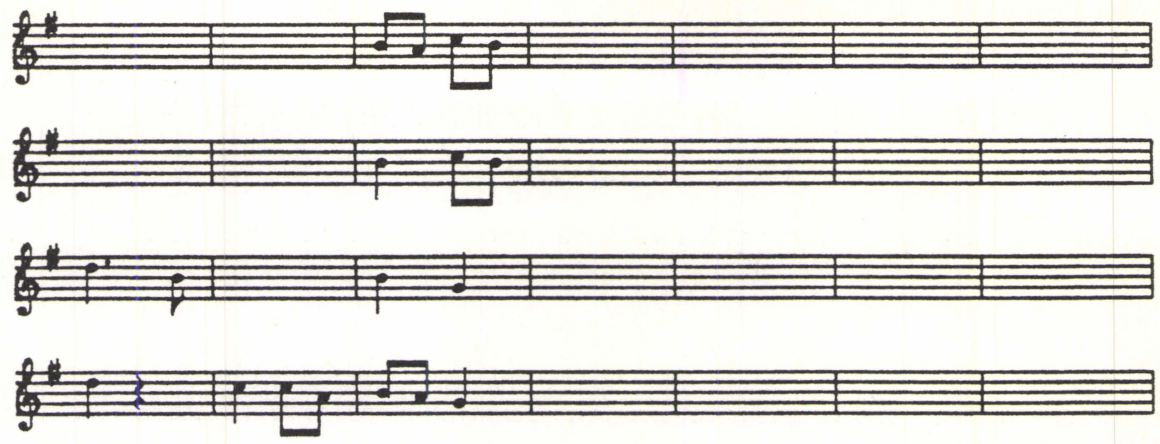
\% W W 15
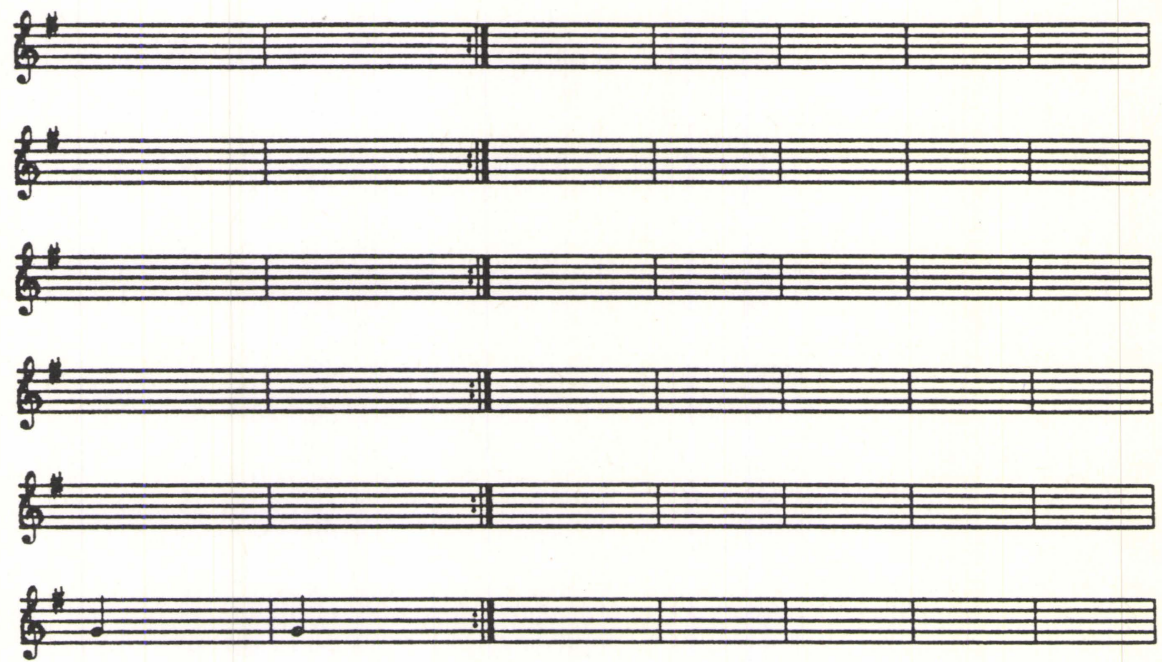
Sävelmä n:o 113
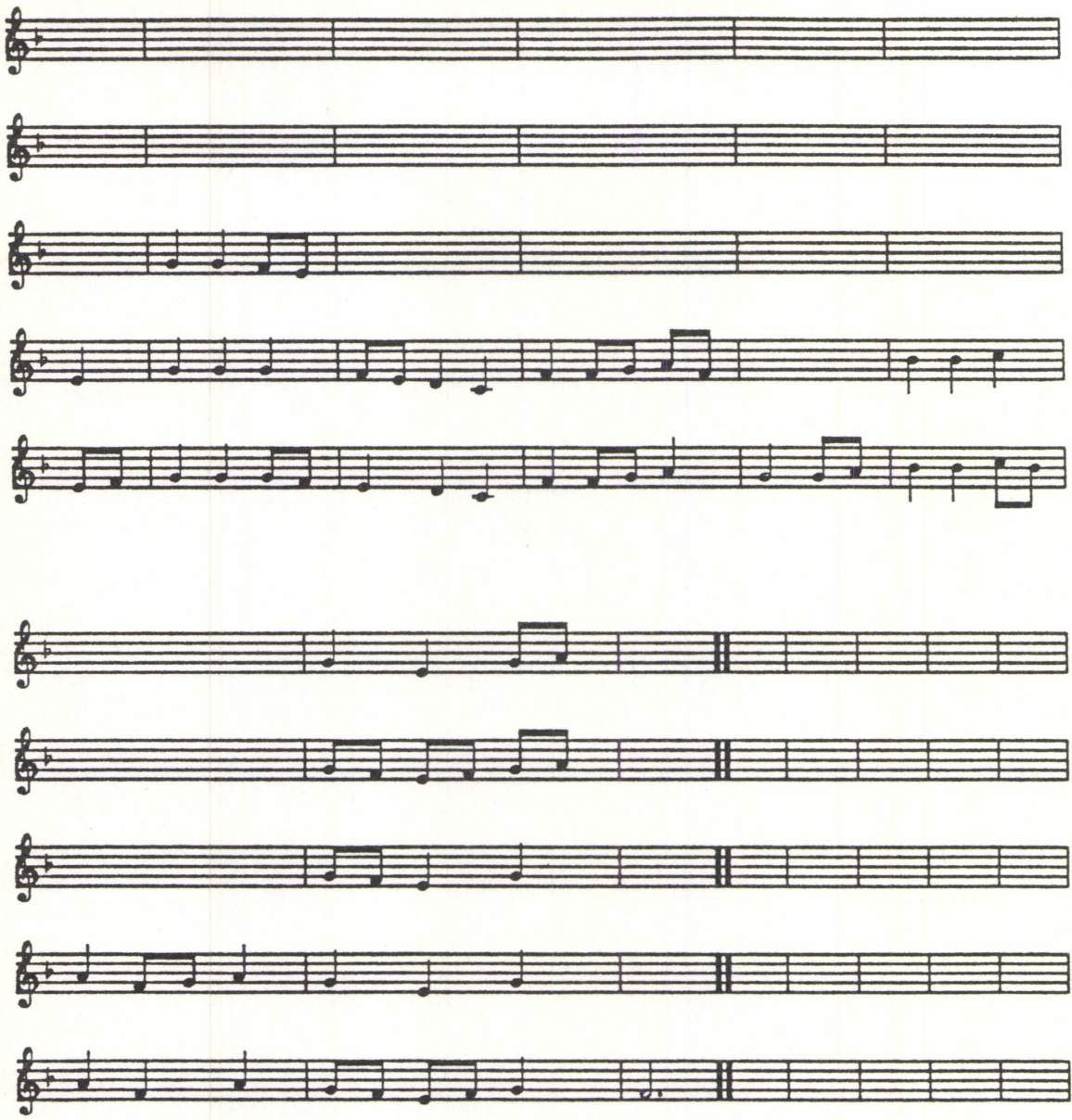
Sävelmä n:o 155

\%OCOCO
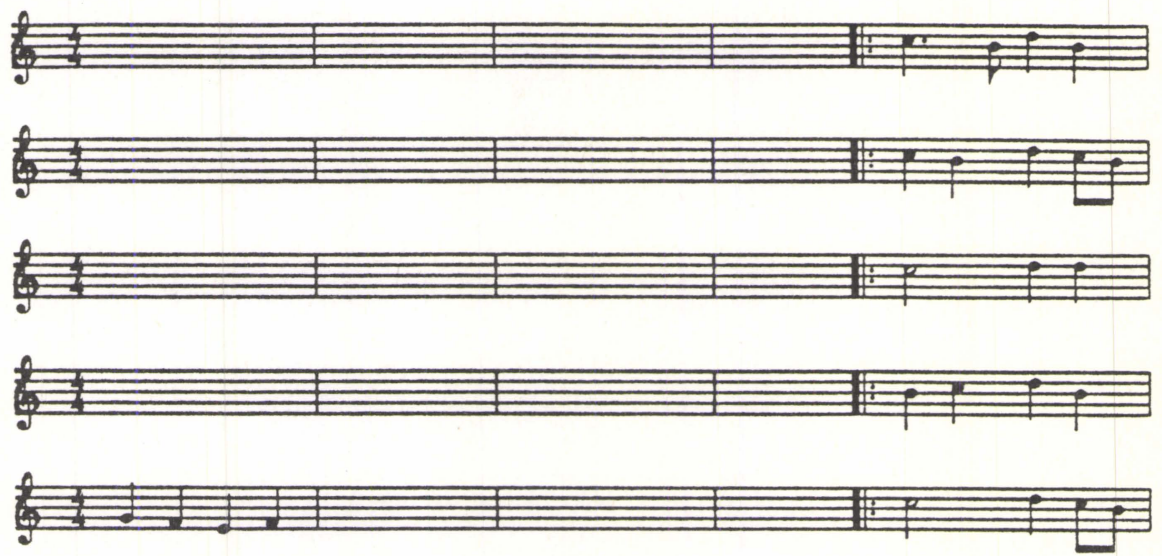

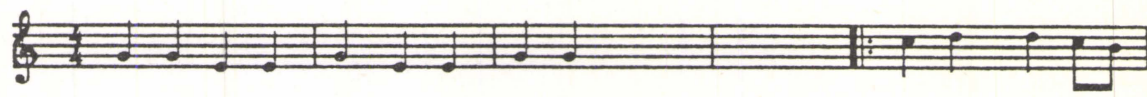
W11\%1\%
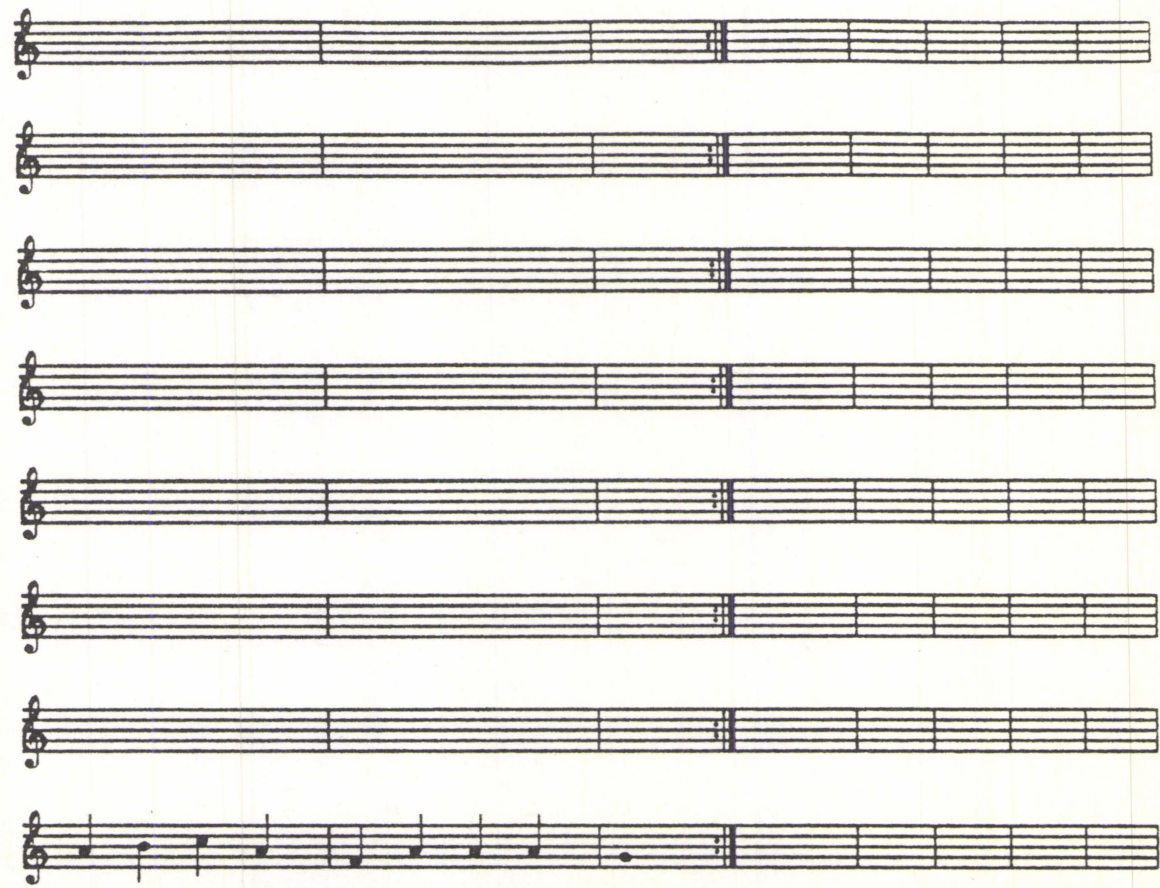
Sävelmä n:o 187
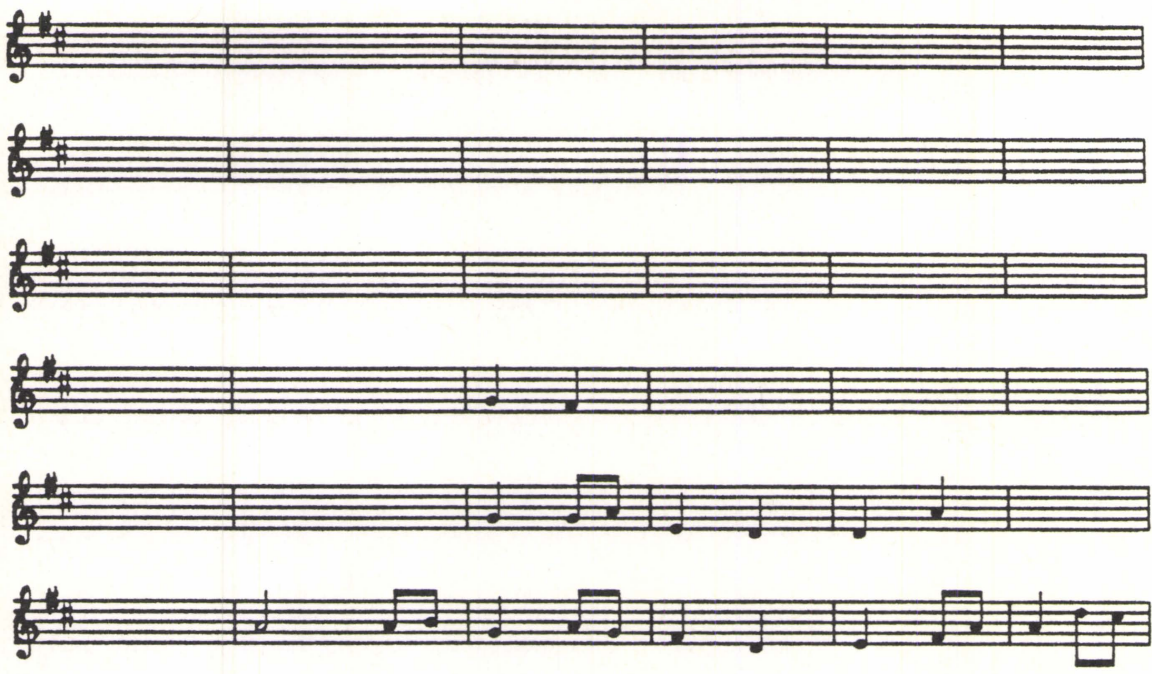

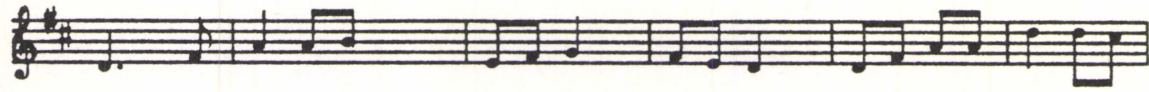
W
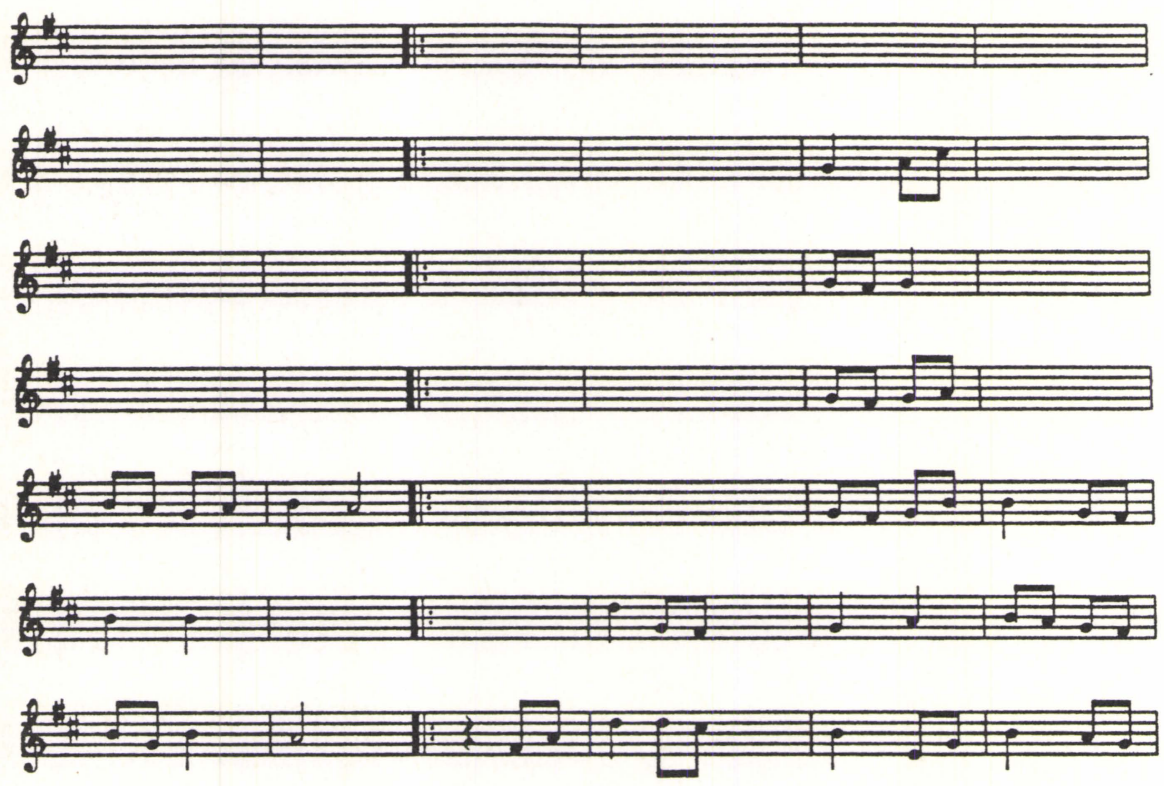
W 1 


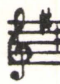

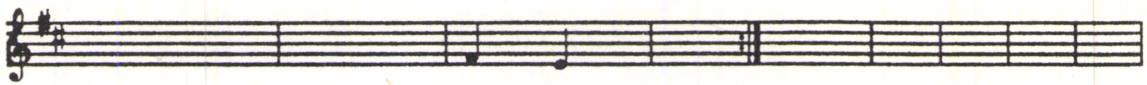

\% W

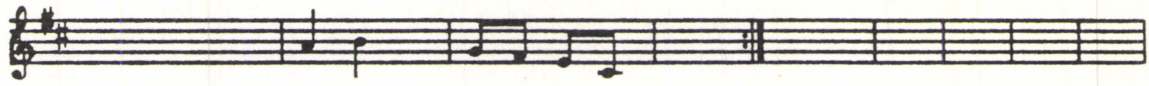

W12)

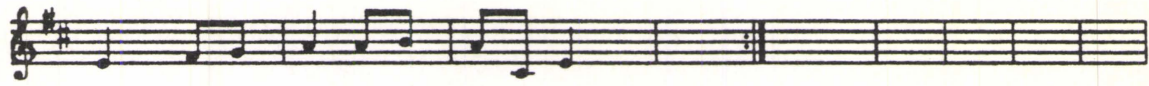

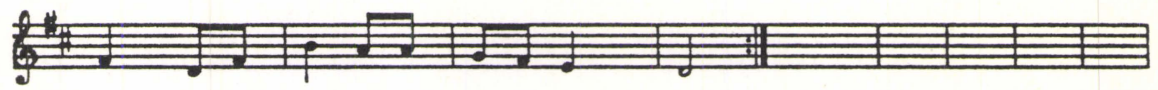

WD

Sävelmä n:o 193
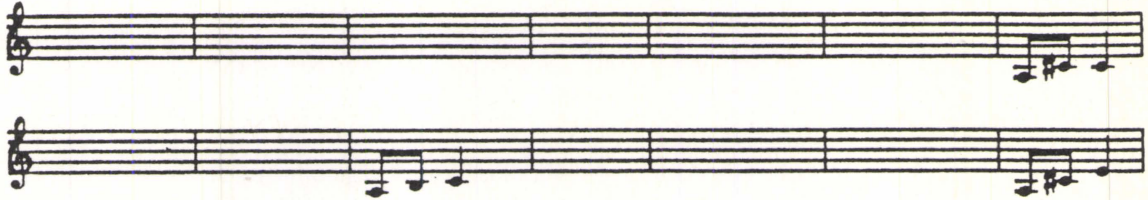

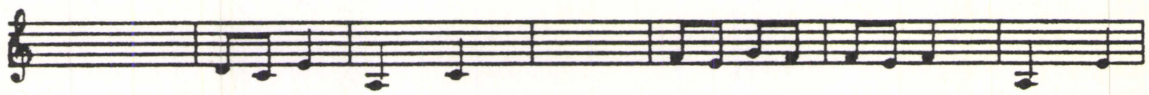

1.15\%
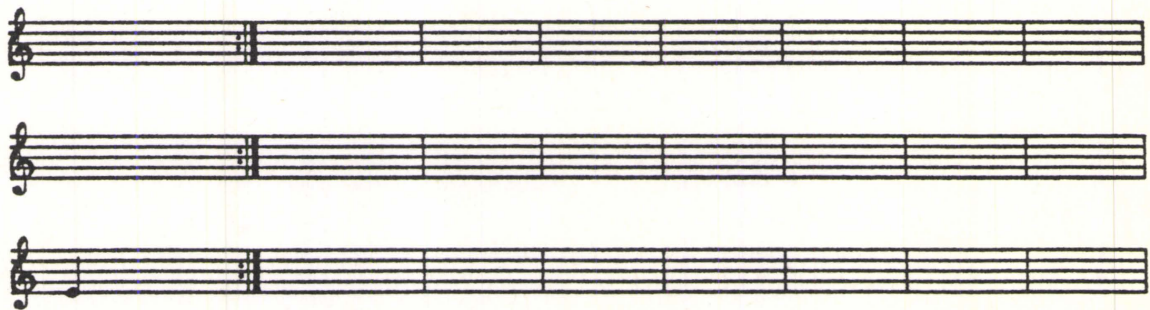


\section{Lähteet}

Kluge Rainer

1974 Faktorenanalytische Typenbestimmung an Volksliedmelodien. Beiträge zur musikwissenschaftlichen Forschung in der DDR. B and 6. VEB Deutscher Verlag für Musik. Leipzig.

Knudsen, T, \& Nielsen, S. \& Schiørring, N

1976 Old popular Ballads of Denmark. Copenhagen.

Ling, Jan \& Jersild, Margareta

1965 "A Method of Cataloguing Vocal Folk Music. A Description of the System Used at the Svenskt Visarkiv". Svenskt Visarkiv 21, 103-114.

Labov, William

1969 "Contradiction, Deletion and Inherent Variability of the English Copula". Language 45.

Louhivuori, Jukka

1983 "Ester Laaksonen rukoilevaisveisaaja Länsi-Suomesta". Kentältä kentälle. Juhlakirja Erkki Ala-Könnin 70-vuotispäiväksi 2.2.1981. Kansanperinteen laitoksen julkaisu 10, 69-89. Tampere.

1986 Hengellisten kansansävelmien muuntuminen. Veisuu innovaation ja tradition paineessa. Tampereen yliopiston Kansanperinteen laitoksen Moniste 10. Tampere.

Martinet, André

1952 "Function, Structure and and Sound Change". Word 8.

Nahkola, Kari

1985 "Variaatio kielitieteessä". Muuntelu ja kulttuuri. Tampereen kansanperinteen laitoksen moniste 7, 149-185. Tampere.

Nattiez, Jean-Jacques

1982 "Taksonomisesta analyysistä tyylin kuvaukseen: Debussyn Syrinx". Musiikin soivat muodot. Jyväskylän yliopiston musiikkitieteen laitoksen jukaisusarja A: tutkielmia ja raportteja no 2, 95-126. Jyväskylä.

Pekkilä, Erkki

1981 "Salomon Katilan juoksuvalssit: kulttuurinen musiikkianalyysi". Musiikki 2, 103-147.

Sapir, Edward

1970 (1921) Language. London.

Sundberg, Johan

1972 "Toward a generative theory of music theory". Svensk Tidskrift för Musikforskning 


\section{Numerical parameters as a device for melody research}

When comparing different versions of folk tunes it is apparent that certain passages are rich in variation, i.e. in a given bar of a phrase one can find several different variant forms (allophones) that resemble each others. On the other hand, some of these component units, paradigms (phonemes) have a fixed form and are not intermixed. Also, certain tunes seem to have attained an established existence, that is, they almost always appear in a fixed form in different parts of a certain area, while other tunes change their shape virtually in every performance. In other cases the tune may be known in a different form in different villages.

The purpose here is to develop a system of parameters to describe the qualities of tune families and, by using empirical research material, to test the adaptability of these parameters in folk tune research. With the help of these parameters it is possible to seek out from a large material the tunes whose qualities of musical distribution are consistent. By examining such tunes it is possible to find answers to questions of musical change.

The research material consisted of tunes collected from the Beseechers in Western Finland. For the analysis, a corpus of ten tunes was selected, and with the help of these, the practicability of parameters was evaluated. In each case there was a calculation of the integrity factor of the tune, the integrity factor of the tune family, the relative frequency of deviant bars, the integrity factor of deviant bars, the integrity factor of dominant versions, the proportional mean value of dominant versions, the integrity factor of bar versions, and the location of deviant bars.

The conclusions were as follows:

- no conclusions should be made on the integrity factor of the tune without a simultaneous examination of the other parameters;

- the relative frequency of deviant bars is especially useful for its value is not affected by the length of the tune nor the number of deviant bars;

- the proportional mean value of the dominant version is useful when applied to the integrity factor of deviant bars;

- the integrity factor is not independent of the other factors; other parameters give the same information as the factors above;

- the values of the integrity factors of bar versions vary according to the values of the integrity factors of dominant versions;

- generally the deviations are clustered on the second bar of the tune; fewest deviations are found in up-beats and the last bar of the phrase. 